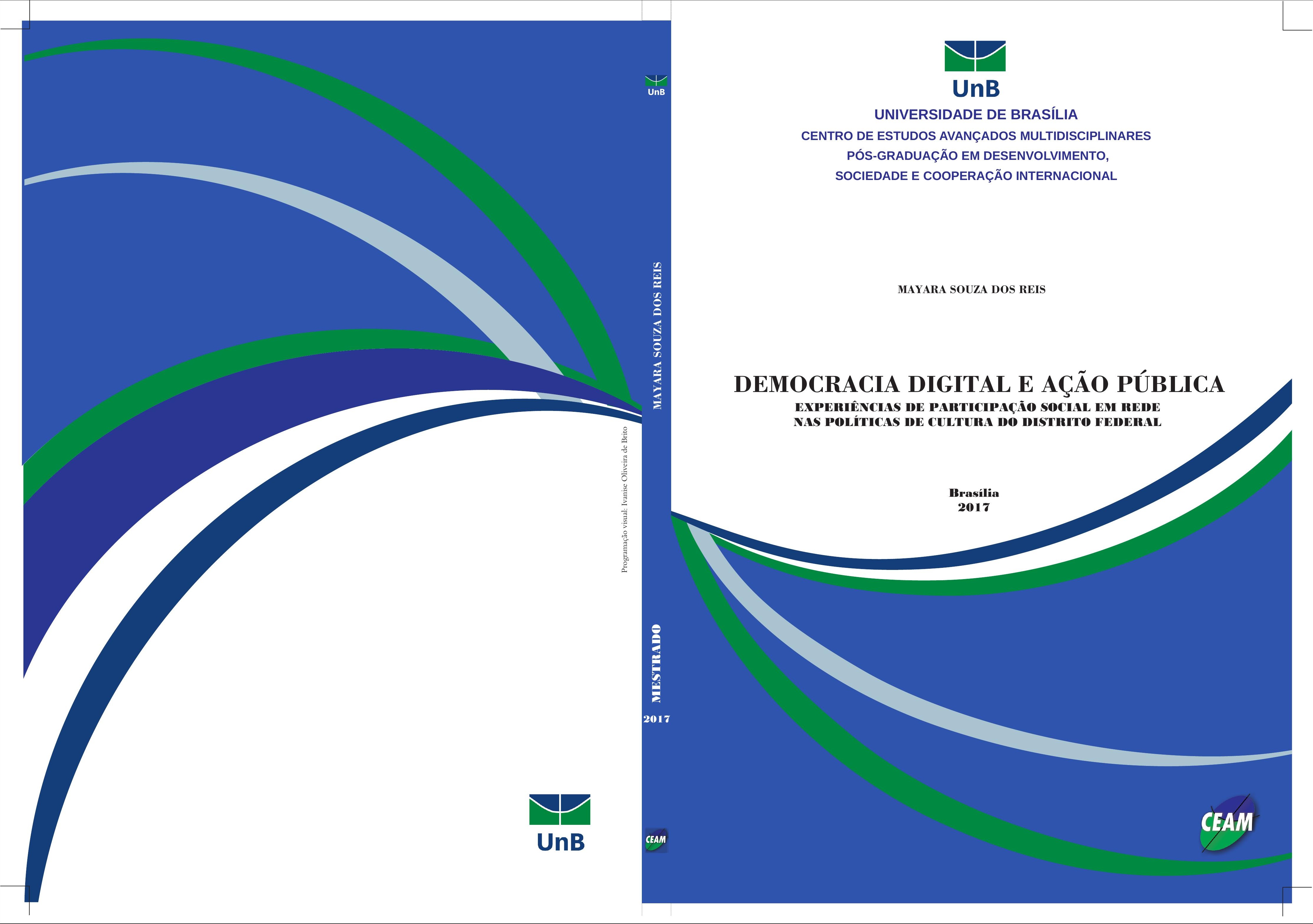




\title{
Democracia digital e ação pública - experiências de participação social em rede nas políticas de cultura do Distrito Federal
}

\author{
Dissertação apresentada ao Programa de Pós-Graduação em \\ Desenvolvimento, Sociedade e Cooperação Internacional da \\ Universidade de Brasília como requisito parcial para obtenção do \\ grau de Mestra. \\ Área de concentração: Políticas e Gestão Pública para o \\ Desenvolvimento. \\ Linha de pesquisa: Desenvolvimento e Políticas Públicas \\ Orientadora: Prof. ${ }^{a}$ Dr. ${ }^{a}$ Maria de Fátima Rodrigues Makiuchi
}

Brasília-DF 


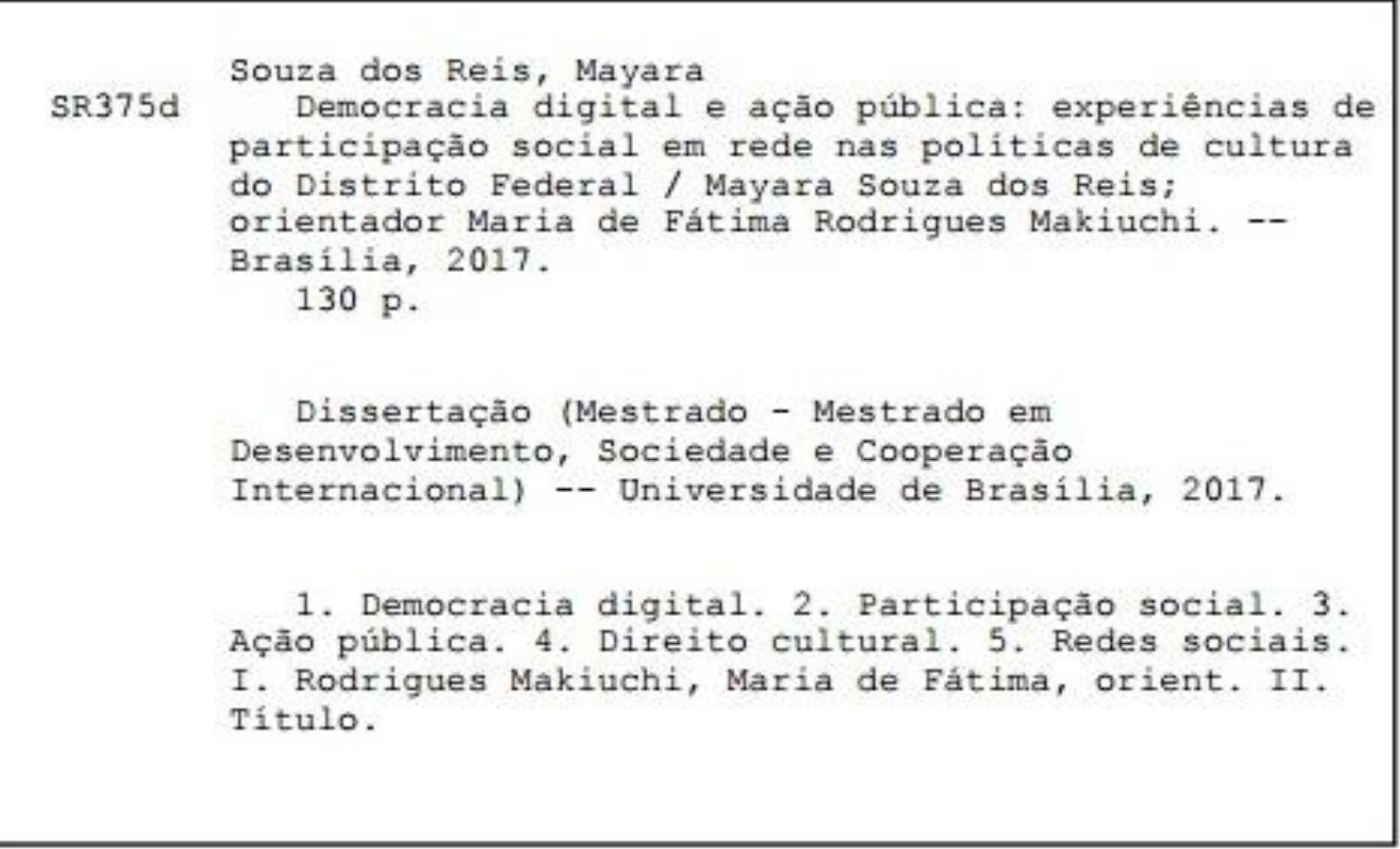


Democracia digital e ação pública - experiências de participação social em rede nas políticas de cultura do Distrito Federal

Dissertação apresentada como requisito parcial para obtenção do grau de Mestra em Desenvolvimento, Sociedade e Cooperação Internacional.

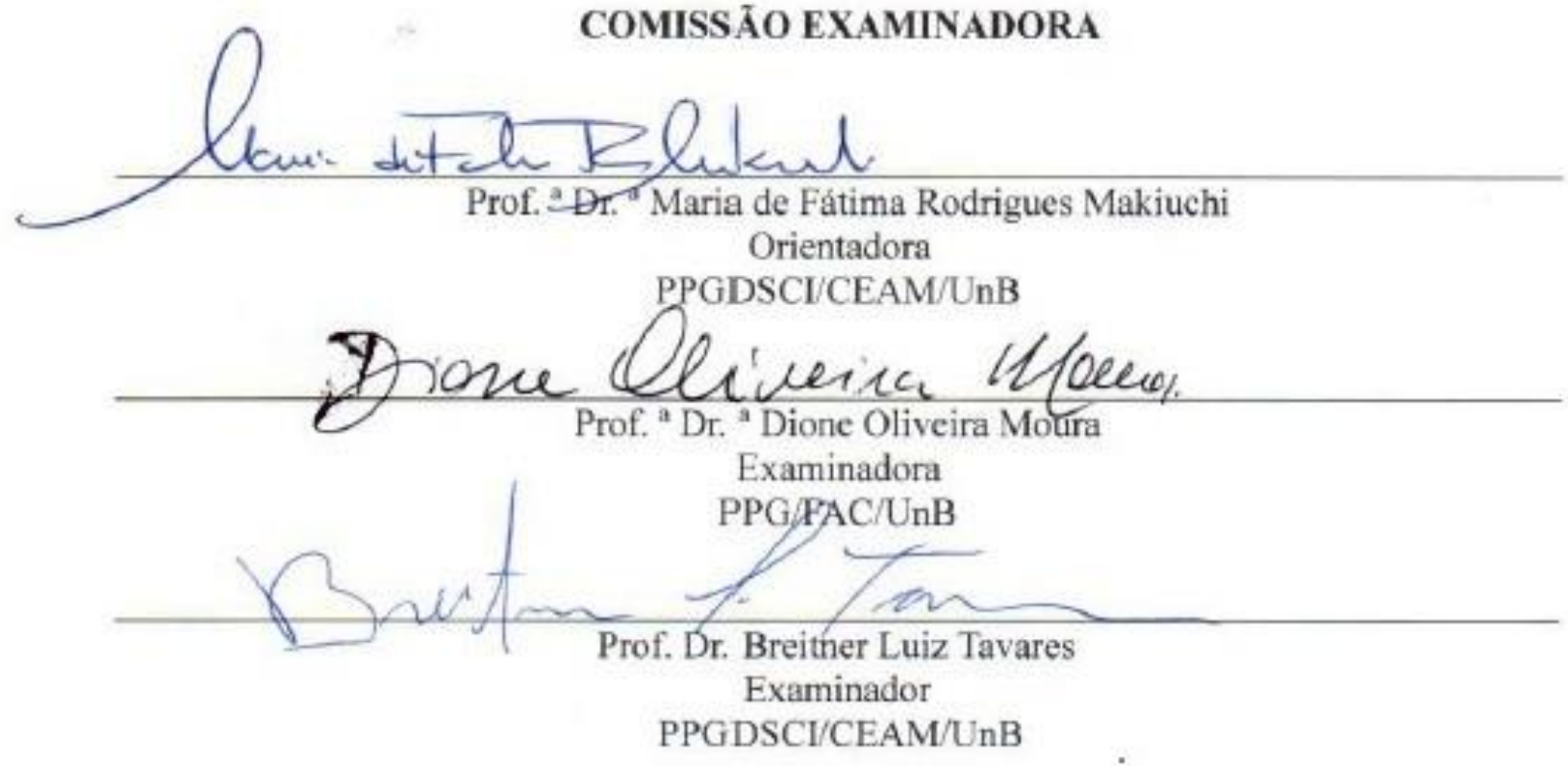

\author{
Prof. ${ }^{\text {a }}$ Dr. ${ }^{\text {" Doriana Daroit }}$ \\ Examinadora Suplente \\ PPGDSCL/CEAM/UnB
}


À minha mãe, pelas valiosas lições de vida. 


\section{AGRADECIMENTOS}

A realização deste estudo não seria possível sem o apoio e a troca de experiências com os colegas e docentes do Programa de Pós-Graduação em Desenvolvimento, Sociedade e Cooperação Internacional (PPGDSCI) da Universidade de Brasília (UnB), em especial os pesquisadores do Observatório de Políticas Públicas Culturais (OPCULT), grupo coordenado pela Prof. ${ }^{\text {a }}$ Dr. ${ }^{\text {a }}$ Maria de Fátima Rodrigues Makiuchi, por quem tive a satisfação de ser orientada neste trabalho e a quem devo os primeiros agradecimentos.

Agradeço também à minha família, principalmente à minha mãe, Veralucia Ferreira Souza, e meus tios, André e Ivonete Nakahara, pelo apoio incondicional, além dos amigos recentes e de longa data que estiveram ao meu lado em cada passo dessa construção.

Por fim, gostaria de agradecer imensamente aos professores Breitner Tavares e Dione Moura pelas valiosas contribuições à pesquisa; aos artistas, gestores públicos, produtores e agitadores culturais entrevistados pela atenção com este estudo; aos colegas do Conselho Regional de Psicologia do Distrito Federal (CRP 01/DF) pelo auxílio para compatibilizar horários, e a todos aqueles que não citei nestas linhas, mas que foram importantes actantes na rede de estudo interdisciplinar que resultou nesta dissertação. 
Nenhuma teoria jamais está de acordo com todos os fatos em seus domínios; contudo, a culpada nem sempre é a teoria. Os fatos são instituídos por ideologias mais antigas, e um conflito entre fatos e teorias pode ser uma prova de progresso.

(Paul Feyerabend) 


\section{RESUMO}

Este estudo de caso apresenta elementos para compreensão de perspectivas e desafios da chamada democracia digital ou e-democracy no âmbito da participação social em políticas públicas. A partir do olhar para o comportamento de atores da sociedade civil e para a relação desses atores com o Estado por meio da internet e dispositivos que lhe são compatíveis, o estudo explora dinâmicas de atuação em rede do segmento artístico e de produção cultural no Distrito Federal a partir da concepção de política como ação pública e de mídias digitais como ferramentas com potencial de incremento da participação civil na condução dos assuntos públicos em benefício dos requisitos da democracia. Para viabilização da pesquisa, adotamos a abordagem metodológica da Teoria Ator-Rede, centrada nos lastros deixados pelas interações, que analisamos a partir do mapeamento de redes formadas na plataforma Facebook e da aplicação de modelo de apreensão deliberativa online com o apoio de entrevistas realizadas com diferentes atores selecionados, na intenção de identificar a) canais de interação entre Estado e sociedade civil na internet com vistas à participação política; b) o grau de aproveitamento desses canais e c) as características e o comportamento das autoridades públicas e da sociedade civil quanto à participação nas decisões de interesse público com o uso de recursos compatíveis com a internet. O estudo aponta perspectivas de ampliação da utilização do meio digital para fins de participação social a partir de características como agilidade, conveniência e diversidade de actantes, e destaca a importância do processo de aprendizado dos diversos atores para lidar com esse novo contexto de articulação em redes digitais, considerando a observação de questões como polarização e assimetrias nas discussões.

Palavras-chave: Democracia digital. Participação social. Ação pública. Direito cultural. Redes sociais. Cibercultura. 


\begin{abstract}
This case study presents elements for understanding the prospects and challenges of the socalled digital democracy or e-democracy in the social participation in public policies. From the look on the actor's behavior of civil society and the relationship of these actors with the State through the Internet and devices that are compatible, the study explores the dynamics of performance in the artistic segment and cultural production networks in the Federal District to form the design of policy as public action and digital media as tools to increase citizen participation potential in the conduct of public affairs for the benefit of democracy requirements. To make possible this survey, we adopted the methodological approach of Actor-Network Theory, centered on weights left by the interactions we reviewed from the mapping of networks formed from the Facebook platform and the application of seizure online deliberative model supported by interviews with different actors, in order to identify a) interaction among channels State and civil society on the internet with a view to political participation; b) the degree of utilization of these channels and c) the characteristics and behavior of public authorities and civil society with regard to participation in the decisions of public interest with usage of resources compatible with the internet. The study points out prospects for expanding the use of digital media for social participation from features such as flexibility, convenience and diversity of actors, and highlights the importance of the learning process of the various actors to address this new context of articulation in digital networks, considering the observation of issues as polarization and asymmetries in the discussions.
\end{abstract}

Keywords: Digital democracy. Social participation. Public action. Cultural rights. Social networks. Cyberculture. 


\section{LISTA DE ILUSTRAÇÕES}

Figura 1 - Pentágono das políticas públicas.................................................................2

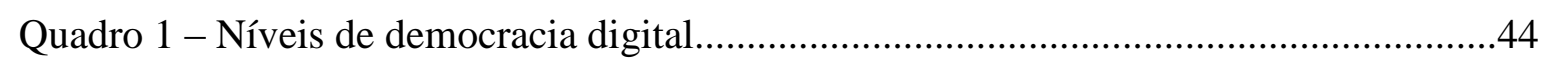

Figura 2 - Histórico de mensagens do grupo de e-mails do Fórum de Cultura do DF........57

Quadro 2 - Fanpages administradas por atores da sociedade civil..................................62

Quadro 3 - Fanpages humorísticas administradas por atores da sociedade civil...............63

Quadro 4 - Fanpages oficiais administradas pelo poder público......................................63

Figura 3 - Comunidades formadas pelas redes de cultura do Distrito Federal na plataforma

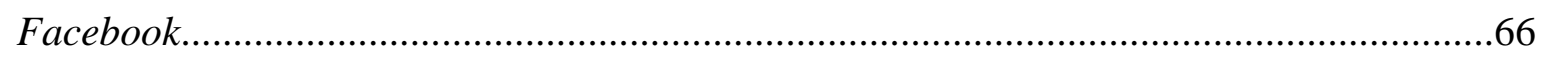

Figura 4 - Exemplo de página identificada dentro da comunidade formada por fanpages de

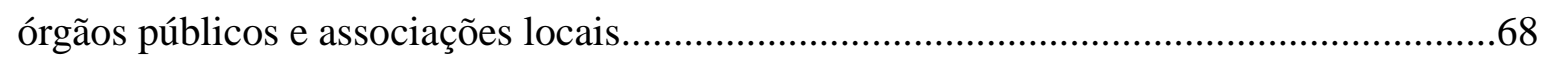

Figura 5 - Exemplo de páginas identificadas dentro da comunidade formada por fanpages

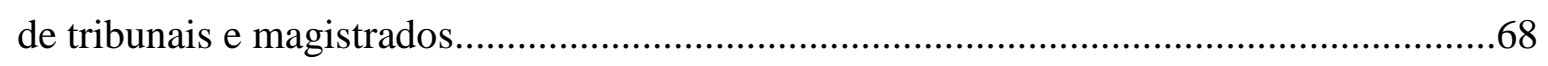

Figura 6 - Exemplo de página identificada dentro da comunidade formada por fanpages de exaltação da cidade de Brasília.

Figura 7 - Exemplo de página identificada dentro da comunidade formada por fanpages de discussões sobre políticas públicas diversas.

Figura 8 - Exemplo de página identificada dentro da comunidade formada por fanpages de economia criativa. .70

Figura 9 - Exemplo de página identificada dentro da comunidade formada por fanpages de artistas de rua. . .70

Figura 10 - Exemplo de página identificada dentro da comunidade formada por fanpages mistas.

Figura 11 - Exemplo de página identificada dentro da comunidade formada por fanpages de agenda cultural... 


\section{LISTA DE TABELAS}

Tabela 1 - Adesão à Plataforma Digital de Governança Colaborativa do Ministério da Cultura..... .54

Tabela 2 - Iniciativas que integram a Plataforma Digital de Governança Colaborativa do Ministério da Cultura. .54

Tabela 3 - Total de publicações das fanpages citando os temas selecionados .80

Tabela 4 - Total de comentários sobre os temas selecionados nas fanpages. .81

Tabela 5 - Graus de entrada e saída das fanpages selecionadas........................................82

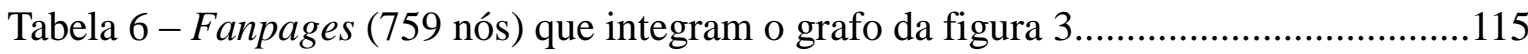




\section{LISTA DE ABREVIATURAS E SIGLAS}

\begin{tabular}{|c|c|}
\hline ARPA & Agência de Projetos de Pesquisa Avançada \\
\hline CEAC & Cadastro de Ente e Agente Cultural \\
\hline CERN & Centro Europeu de Pesquisas Nucleares \\
\hline CGI & Comitê Gestor da Internet no Brasil \\
\hline CLDF & Câmara Legislativa do Distrito Federal \\
\hline CNPC & Conselho Nacional de Política Cultural \\
\hline DF & Distrito Federal \\
\hline Embrafilme & Empresa Brasileira de Filmes \\
\hline FAC & Fundo de Apoio à Cultura do Distrito Federal \\
\hline Funarte & Fundação Nacional de Artes \\
\hline GDF & Governo do Distrito Federal \\
\hline$H T M L$ & Hypertext Markup Language \\
\hline IBGE & Instituto Brasileiro de Geografia e Estatística \\
\hline LIC & Lei de Incentivo à Cultura do Distrito Federal \\
\hline LOA & Lei Orçamentária Anual \\
\hline MinC & Ministério da Cultura \\
\hline MPDFT & Ministério Público do Distrito Federal e Territórios \\
\hline NSA & National Security Agency \\
\hline OCDE & Organização para a Cooperação e Desenvolvimento Econômico \\
\hline ONGs & Organizações Não Governamentais \\
\hline ONU & Organização das Nações Unidas \\
\hline PDC & Plano Distrital de Cultura \\
\hline PNAD & Pesquisa Nacional por Amostra de Domicílios \\
\hline PNC & Plano Nacional de Cultura \\
\hline PPCUB & Plano de Preservação do Conjunto Urbanístico de Brasília \\
\hline Secult & Secretaria de Estado de Cultura do Distrito Federal \\
\hline Sphan & Serviço do Patrimônio Histórico e Artístico Nacional \\
\hline $\mathrm{SNC}$ & Sistema Nacional de Cultura \\
\hline SNIIC & Sistema Nacional de Informações e Indicadores Culturais \\
\hline
\end{tabular}


SNS Social Networking Sites

TAR Teoria Ator-Rede

TJDFT Tribunal de Justiça do Distrito Federal e Territórios

TCLE Termo de Consentimento Livre e Esclarecido

TICs Tecnologias de Informação e Comunicação

UIT União Internacional de Telecomunicações

Unesco Organização das Nações Unidas para a Educação, Ciência e Cultura

URL Uniform Resource Locator

WWW $\quad$ World Wide Web 


\section{SUMÁRIO}

INTRODUÇÃO. .15

1. DEMOCRACIA DIGITAL, AÇÃO PÚBLICA E DESENVOLVIMENTO. .21

1.1 DESENVOLVIMENTO DEMOCRÁTICO, PLURALISMO E A POLÍTICA COMO AÇÃO PÚBLICA.

1.2 DELIBERAÇÃO E PARTICIPAÇÃO SOCIAL NA TEORIA DEMOCRÁTICA CONTEMPORÂNEA.......................................................28

1.3 REDES SOCIAIS, DEMOCRACIA DIGITAL E CIBERCULTURA.................35

2. DIREITO CULTURAL E POLÍTICAS PÚBLICAS DE CULTURA. . .47

2.1 DIVERSIDADE E DIREITO CULTURAL

2.2 A CONSTRUÇÃO DAS POLÍTICAS PÚBLICAS DE CULTURA NO BRASIL

2.3 DELIBERAÇÃO E PARTICIPAÇÃO SOCIAL NAS POLÍTICAS CULTURAIS.

3. PARTICIPAÇÃO SOCIAL E DELIBERAÇÃO ONLINE NAS POLÍTICAS DE

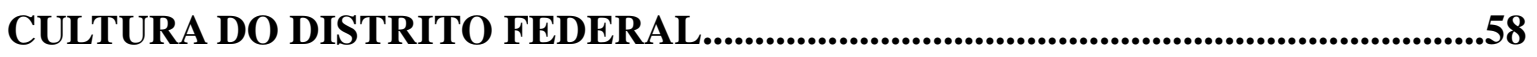

3.1 A ARTICULAÇÃO DE REDES DE ARTISTAS E PRODUTORES CULTURAIS NO DISTRITO FEDERAL..........................................................60

3.2 PARTICIPAÇÃO SOCIAL EM REDE E APREENSÃO DELIBERATIVA

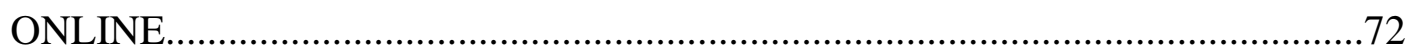

3.2.1 Teoria Ator-Rede e apreensão deliberativa online...................................73

3.2.2 Apreensão deliberativa e o olhar sobre a estrutura da comunicação online. .74

3.2.3 Elementos de análise em cultura política e ideologia..............................76

3.2.4 Pontos de atenção nos critérios de design e conteúdo..............................76

3.2.5 Análise do processo discursivo na apreensão deliberativa online............76

3.3 LIMITES E PERSPECTIVAS DA DEMOCRACIA DIGITAL NAS POLÍTICAS DE CULTURA DO DISTRITO FEDERAL.....................................78 
3.3.1 Análise da estrutura comunicativa das fanpages. .83

3.3.2 Observações sobre cultura política e ideologia. .86

3.3.3 Avaliação de design e conteúdo das páginas selecionadas.......................88

3.3.4 Análise do processo discursivo nas fanpages.........................................89

3.3.5 Concepção dos actantes sobre deliberação e participação social pela internet.

APÊNDICE A - TERMO DE CONSENTIMENTO LIVRE E ESCLARECIDO (TCLE)

APÊNDICE B - ROTEIRO DE ENTREVISTA SEMIESTRUTURADA APLICADA A ATOR DA SOCIEDADE CIVIL (ADMINISTRADOR DE FANPAGE).

APÊNDICE C - ROTEIRO DE ENTREVISTA SEMIESTRUTURADA APLICADA A ATOR DA SOCIEDADE CIVIL (MEMBRO/ SEGUIDOR DE FANPAGE).

APÊNDICE D - ROTEIRO DE ENTREVISTA SEMIESTRUTURADA APLICADA A ENTE ESTATAL (ADMINISTRADOR DE FANPAGE).

APÊNDICE E - ROTEIRO DE ENTREVISTA SEMIESTRUTURADA APLICADA A ENTE ESTATAL (AUTORIDADE/ GESTOR PÚBLICO).........114 APÊNDICE F - FANPAGES (759 NÓS) QUE INTEGRAM O GRAFO DA FIGURA 3. 


\section{INTRODUÇÃO}

A articulação de atores sociais voltados à construção ou regulação de aspectos das práticas políticas tem sido movimento corrente nas democracias liberais e, em especial, na América Latina desde a segunda metade da década de 1980 (DAGNINO, 2004), em face da onda de ceticismo quanto à capacidade de representação social dos partidos políticos tradicionais.

O debate contemporâneo em teoria democrática tem dedicado especial atenção ao modelo de democracia deliberativa que, em rigor, aborda a concepção de uma sociedade na qual as decisões políticas devem ser alcançadas por meio de um processo de deliberação entre cidadãos livres e iguais, recuperando a dimensão moral que vinha perdendo destaque no campo da chamada teoria política empírica que dominou boa parte do século passado (MOUFFE, 2005).

No lugar de uma política agregativa de poder e interesse, os deliberacionistas costumam defender uma ação qualificada, na qual os cidadãos considerariam os problemas públicos por meio de uma racionalização conjunta, com o intuito de resolver as questões por meio do discurso, e valorizando essencialmente o poder do argumento dos participantes (HABERMAS, 2003; SAMPAIO, 2012).

Contudo, como observa Touraine, a sociedade civil "é o domínio dos atores sociais que são orientados por valores culturais e, ao mesmo tempo, por relações sociais, muitas vezes, conflitantes" (TOURAINE, 1996a, p. 63). Sob esse aspecto, seria responsabilidade do Estado, entendido como "os poderes que elaboram e defendem a unidade da sociedade nacional diante das ameaças e problemas externos e internos" (TOURAINE, 1996a, p. 63), a defesa dos interesses coletivos e a proteção das minorias.

Mouffe (2005, p. 16-17) segue a provocação, ressaltando que "o domínio da política - mesmo quando questões básicas como justiça ou princípios fundamentais estão envolvidos - não é um terreno neutro que poderia ser isolado do pluralismo de valores", destacando que o que realmente está em jogo na fidelidade a instituições democráticas é a constituição de um conjunto de práticas que façam possível a criação de sujeitos democráticos, não sendo somente uma questão de justificação racional, mas de disponibilidade de formas democráticas de individualidade e subjetividade.

No Brasil, a Constituição Federal de 1988 expandiu significativamente a concepção de cidadania e inaugurou uma nova perspectiva sobre a relação entre Estado e sociedade 
civil, com destaque ao gradativo avanço dos mecanismos formais de diálogo, ao surgimento de novas formas de representação dentro do que se convencionou chamar de sociedade civil organizada (AVRITZER, 2007) e, mais recentemente, à demanda social por iniciativas que promovam o aumento da diversidade de agentes, de agências e de agendas na esfera pública e nas instâncias de decisão política (MAIA; GOMES; MARQUES, 2011).

Essa reivindicação de segmentos da sociedade civil considera a formação do Estado brasileiro que, em seus arranjos, esteve historicamente propenso a sobrepor as esferas pública e privada, manter privilégios e voltar-se à garantia de espaço das elites no controle dos assuntos de interesse coletivo, em detrimento das minorias políticas (HOLANDA, 1995), de modo que a ação social viria a ser compreendida como dinâmica com potencial de direcionar o desenvolvimento do conjunto da sociedade.

$\mathrm{O}$ avanço das tecnologias digitais de informação e comunicação tem reforçado o debate sobre a deliberação e a participação civil nas democracias contemporâneas, uma vez que ferramentas online se mostram cada vez mais capazes de organizar, armazenar e expor informação de interesse geral em larga escala para grandes contingentes de cidadãos, assumindo também maiores possibilidades de interação com implicações para motivação e oportunidade de envolvimento na vida pública (SAMPAIO, R. C.; BARROS, S. A. R.; MORAIS, R., 2012a), diferente dos meios de comunicação de massa tradicionais, comumente controlados por oligopólios no Brasil.

Parte significativa das discussões centra-se na análise de ferramentas e iniciativas estatais e, mais recentemente, na observação de conteúdos tornados públicos em sites de mídias sociais, sendo muito comum em estudos norte-americanos e europeus o conjunto de abordagens interessadas em verificar como as tecnologias digitais contribuem para resolver o déficit de participação política que afeta as democracias liberais contemporâneas (MAIA; GOMES; MARQUES, 2011) ou identificar elementos da cibercultura e do ciberespaço meio no qual esse contexto emerge e se transforma - tais como a interconexão, o advento das comunidades virtuais e a difusão da chamada inteligência coletiva (LÉVY, 1999).

Nesse sentido e herdando reflexões da teoria política e da teoria democrática, o conceito de democracia digital ou e-democracy passou a ser adotado tanto por teóricos de diversas áreas do conhecimento como por atores políticos e organismos internacionais, sendo o mesmo entendido como qualquer forma de emprego de dispositivos 
(computadores, celulares, palmtops...), aplicativos (programas) e ferramentas (fóruns, sites, mídias sociais) de tecnologias digitais de comunicação para suplementar, reforçar ou corrigir aspectos das práticas políticas e sociais do Estado e dos cidadãos, em benefício do teor democrático da comunidade política (MAIA; GOMES; MARQUES, 2011).

Essa concepção encontra ressonância tanto entre os participacionistas como entre os teóricos deliberacionistas da democracia, que buscam, sobretudo no âmbito procedimental, elementos de qualificação das democracias liberais contemporâneas para além de eleições periódicas de representantes, ao considerar que, sendo a igualdade política uma condição para a democracia, esta não significa somente a atribuição de direitos iguais, mas também a compensação de desigualdades, como destaca Touraine:

\begin{abstract}
A ideia de democracia não pode ficar separada da ideia de direitos e, por conseguinte, não pode ser reduzida ao tema do governo da maioria [...]. Portanto, a democracia não pode ser reduzida a instituições públicas, a uma definição de poderes ou, até mesmo, ao princípio da eleição livre, em intervalos regulares, dos dirigentes; é inseparável de uma teoria e prática do direito. (TOURAINE, 1996a, p. 38)
\end{abstract}

O conceito de esfera pública, entendida como "espaço de trato comunicativo e racional entre as pessoas" (HABERMAS, 2007, p. 18-19) ou "estrutura comunicacional do agir orientado pelo entendimento" (HABERMAS, 2003, v. .II, p. 92) é fundamental nesse sentido e seu princípio estruturante, como nas raízes das reflexões de Jürgen Habermas, está ancorado na capacidade de racionalização pública ou de aprendizado coletivo, ressaltando-se que, tanto no exercício do filósofo alemão como nos trabalhos de outros deliberacionistas, esses conceitos estejam vinculados a uma dimensão normativa que não necessária e imediatamente encontra todos os seus elementos no campo empírico, sobretudo quando se considera a pluralidade de sujeitos envolvidos na concepção de soberania popular ou na interação social que geraria o poder público (MOUFFE, 2005).

Para Habermas são os "constrangimentos procedimentais" materializados institucionalmente contra forças e coerções e, portanto, um conjunto dinâmico de fatores, que devem eliminar as posições que não podem ser aceitas pelos participantes do debate democrático ou da racionalização pública, gerando assim as condições para a deliberação:

A soberania dissolvida comunicativamente faz-se valer no poder dos discursos públicos, que nasce de espaços públicos autônomos, mas tem de tomar forma nas decisões de instituições de formação de opinião e vontade concebidas democraticamente, porque a obrigação de responder pelas decisões requer uma 
É por meio da observação dessas dinâmicas de ação pública com o apoio da internet e dispositivos compatíveis que se desenvolve esta investigação, na qual realizamos um estudo de caso sobre as redes de participação em políticas públicas de cultura no Distrito Federal a partir da análise de interações em páginas hospedadas na plataforma digital Facebook.

Nossa opção pelo estudo de caso (LAVILLE; DIONNE, 2008; CRESWELL, 2007) parte do objetivo de explorar em profundidade um movimento que nos parece ilustrativo do objeto democracia digital, sendo ainda uma abordagem que possui a capacidade de lidar com uma ampla variedade de fontes de dados, trabalhados nesta pesquisa a partir de documentos, mapeamento de mídias digitais e entrevistas realizadas com atores selecionados.

Tendo em vista o questionamento que motiva este estudo sobre os desafios e as perspectivas para efetivação da participação social por meio da internet, esse trabalho buscar entender: a) qual a concepção que atores sociais e entes estatais possuem sobre a participação social por meio da internet e dispositivos compatíveis; b) se canais de interação para fins políticos na internet - sejam os oferecidos pelo Estado ou aqueles articulados pela sociedade civil - cumprem os requisitos democráticos e atendem às características do ciberespaço; c) qual o nível de interação entre Estado e sociedade civil por meio da internet; d) se debates desenvolvidos no campo digital são efetivados em ações e deliberações públicas e e) em que medida a organização social de atores em redes na grande rede mundial de computadores tende a fortalecer ou enfraquecer a deliberação pública.

Nota-se que é de nosso interesse desenvolver uma investigação sobre a democracia digital que consiga oferecer elementos para além da análise de ferramentas e instrumentos ofertados por entes estatais - como comumente vêm sendo desenvolvidos os estudos em democracia digital (MAIA; GOMES; MARQUES, 2011) - mas que consiga sobretudo identificar como atores da sociedade civil agem, dentro de uma perspectiva de rede e em um contexto de imersão no ciberespaço, para fins de participação no desenvolvimento de políticas públicas e na interação com o Estado e com as próprias redes, consideradas aqui 
atores com capacidade de agência (actantes ${ }^{1}$, no conceito empregado pela Teoria AtorRede) nos processos de articulação.

A relevância de tal proposta tem sido levantada por episódios recentes e cada vez mais frequentes - não apenas no Brasil, mas em diversos países do globo - de articulação de indivíduos e grupos no sentido exigir novas práticas democráticas e formas de ação pública ou, como sugere Castells (2013):

Das profundezas do desespero, por toda parte, surgiram um sonho e um projeto: reinventar a democracia, encontrar maneiras que possibilitem aos seres humanos administrar coletivamente suas vidas de acordo com os princípios amplamente compartilhados em suas mentes e em geral negligenciados em sua experiência diária." (Idem, p. 176-177)

Para viabilização do estudo, adotamos a abordagem metodológica da Teoria AtorRede (LATOUR, 1994; 2011; 2012), centrada nos lastros deixados pelas interações, que analisamos a partir de instrumentos voltados ao mapeamento de redes em mídias digitais (RECUERO; BASTOS; ZAGO, 2015) e da aplicação de modelo de apreensão deliberativa online (MAIA, R. C. M; GOMES, W.; MARQUES, F. P. J. A., 2011; SAMPAIO, 2012; SAMPAIO; BARROS; MORAIS, 2012).

Nosso objetivo central, ressaltamos, foi compreender pontos limitadores e perspectivas para efetivação do potencial de incremento da participação social pela internet e dispositivos de conexão em rede nas decisões de interesse público, identificando i) canais de interação entre Estado e sociedade civil na internet com vistas à participação política; ii) o grau de aproveitamento desses canais e iii) as características e o comportamento das autoridades públicas e da sociedade civil quanto à participação nas decisões de interesse público com o uso de recursos compatíveis com a internet.

Assim, no capítulo 1 apresentamos um panorama das teorias que permeiam esta investigação, refletindo sobre diferentes correntes de estudo da democracia contemporânea, sua interface com as teorias do desenvolvimento e com as pesquisas mais recentes em cibercultura e democracia digital. No segundo capítulo, apresentamos um

1 A Teoria Ator-Rede costuma empregar o termo "actante", originário do estudo da literatura, na tentativa de apreender a dinâmica das ações. Para Latour (2012, p. 75), utilizar a palavra "ator" sem os devidos esclarecimentos "significa que jamais fica claro quem ou quê está atuando quando as pessoas atuam, pois $\mathrm{o}$ ator, no palco, nunca está sozinho ao atuar." $\mathrm{O}$ ator seria, nessa perspectiva, aquilo que muitos outros levam a agir. Um dos influenciadores de Latour é Algirdas Julien Greimas, linguista lituano (1917-1992) que utiliza o termo actante para se referir aos participantes ativos (humanos e não-humanos) de determinada ação. 
breve histórico do desenvolvimento das políticas públicas de cultura no Brasil até os dias atuais, direcionando às dinâmicas observadas na capital federal e arredores. Por fim, no capítulo 3 descrevemos nosso percurso metodológico para análise das redes de participação em políticas públicas de cultura no ambiente digital, expondo os resultados obtidos no estudo voltado para o caso do Distrito Federal, no qual pudemos identificar elementos para compreensão do nosso objeto de estudo, a democracia digital, a partir dos questionamentos apresentados nesta dissertação.

O estudo aponta perspectivas de ampliação da utilização do meio digital para fins de participação social a partir de características como agilidade, conveniência e diversidade de agências, agendas e agentes na ação pública com reflexos sobre a formação ou o aprimoramento de sujeitos políticos, e destaca a importância do processo de aprendizado dos diversos actantes para lidar com esse novo contexto de articulação em redes digitais, de forma a promover o aprofundamento dos debates, a descentralização dos discursos, o aumento da reciprocidade e do respeito nas interações, bem como reduzir a resistência dos diversos atores a novos formatos de ação e gestão pública, traduzidos em iniciativas e procedimentos que venham a ter respostas institucionais satisfatórias, democraticamente relevantes e compatíveis com modelos de desenvolvimento comprometidos com a promoção das capacidades humanas dentro de um projeto socialmente responsável e sustentável. 


\title{
1. DEMOCRACIA DIGITAL, AÇÃO PÚBLICA E DESENVOLVIMENTO
}

\begin{abstract}
Ainda que a sociedade civil seja tida como soberana genuína do ideário democrático, o grau de envolvimento de seus atores nos assuntos públicos tem se modificado ao longo da história da democracia. Se até a década de 1960 havia, entre as principais correntes da teoria democrática contemporânea, uma tendência de repelir o envolvimento político da esfera civil - em boa parte atribuído a circunstâncias históricas, como a existência de regimes totalitários e populistas nos anos 1930 e 1940 -, a partir da década de 1970, no auge dos movimentos trabalhistas e estudantis nos Estados Unidos e Europa, passa-se a defender uma maior aproximação entre a esfera política e a esfera civil na tomada de decisões até então restritas, quase que exclusivamente, aos plenários e gabinetes institucionais (MARQUES, 2008).

Esse novo movimento vem se fortalecendo ao longo das últimas décadas com a discussão e a criação de mecanismos de participação social em diversos países, de modo que, cada vez mais, os atores sociais têm visto a necessidade de se articularem com outros indivíduos e grupos com a mesma identidade social ou política, "a fim de ganhar visibilidade, produzir impacto na esfera pública e obter conquistas para a cidadania" (SCHERER-WARREN, 2006).
\end{abstract}

A articulação de atores sociais sob a lógica de redes e, mais recentemente, os novos movimentos estruturados a partir da relação com a grande rede mundial de computadores têm levado muitos estudiosos a refletir sobre o potencial democrático da internet. Se por um lado boa parte dos teóricos entende o ambiente digital como uma nova ágora para o debate público, por outro têm ganhado força muitas correntes céticas em relação à influência da Rede sobre a participação política.

Em geral, esse segundo grupo argumenta que a internet tende a trazer malefícios como a fragmentação dos debates, apontando a possibilidade (já com alguns exemplos reais) de que tais ferramentas sejam empregadas para promover a organização e a participação de grupos avessos ao debate e ao respeito às diferenças. Além disso, afirmam que "o exercício de uma influência política efetiva por parte dos cidadãos se mostra imperceptível, sobretudo por conta da indisposição do sistema representativo em recolher e considerar contribuições da sociedade" (MARQUES In: MAIA; GOMES; MARQUES, 
2012, p. 96).

Em 2014, um novo argumento ganhou força entre os céticos, quando o exfuncionário da National Security Agency (NSA) - agência de segurança estadunidense -, Edward Snowden, tornou públicos os programas de vigilância globais conduzidos pela instituição. Nesse mesmo ano, a Presidência da República no Brasil sancionou o Marco Civil da Internet, Carta Magna para o meio digital no país.

Em 2016, após consulta pública, foi assinado o decreto presidencial que regulamentou o Marco Civil da Internet, o que ainda passa por análise de especialistas quanto à segurança e garantias constitucionais dos usuários da internet e operadoras no país, juntamente com outras legislações já vigentes, como a Lei de Crimes Cibernéticos, de 2012, e outras em tramitação. Como exemplo destas últimas, citamos propostas de leis que se referem aos mecanismos de participação social no Brasil e projetos de controle dos conteúdos disponibilizados na rede mundial de computadores por perfis anônimos e/ou falsos.

Todo esse movimento tem provocado as indagações que apresentamos na introdução e que motivaram este estudo, e não poderíamos iniciar uma investigação sobre o objeto democracia digital sem antes revisar os principais conceitos com os quais trabalha.

O referencial teórico deste trabalho pretende dar suporte à análise de três conceitos principais: democracia digital, ação pública e redes sociais, sendo também relevante para as experiências analisadas destacar o que se entende por participação social, direito cultural e cibercultura.

Democracia digital ou e-democracy é compreendida como qualquer forma de emprego de dispositivos, aplicativos e ferramentas de tecnologias digitais de comunicação para suplementar, reforçar ou corrigir aspectos das práticas políticas e sociais do Estado e dos cidadãos, em benefício do teor democrático da comunidade política (MAIA; GOMES; MARQUES, 2011), explorando assim a cibercultura e o ciberespaço (LÉVY, 1999), contexto no qual acontece e a partir do qual são moldados os comportamentos sob influência das tecnologias digitais.

A política pública é aqui tratada dentro de uma perspectiva distinta da tradição clássica, centrada na estrutura burocrática do Estado. Parte-se da compreensão de política como ação pública (LASCOUMES; LE GALÈS, 2012), abordagem na qual é entendida como um objeto complexo e dinâmico, estruturado não somente por atores e instituições, 
mas também por representações, processos e resultados. Essa é uma perspectiva que consideramos compatível com as reflexões sobre as novas formas de articulação de redes sociais no ambiente digital e a estruturação da esfera pública, no que se refere ao esforço de entender a reciprocidade entre as esferas informais do mundo da vida e as esferas formais dos processos de tomada de decisão institucionalizados, de modo a transformar o poder comunicativo, como descrito por Habermas (2007), em poder de deliberação.

O conceito de redes sociais é aqui utilizado como categoria de análise e perspectiva metodológica dentro da Teoria Ator-Rede ou TAR (LATOUR, 2012). Essa compreensão conduz a um olhar dinâmico sobre os processos sociais, fundamentado na observação dos lastros construídos mediante as interações dos actantes, o que estamos analisando a partir de diversas técnicas de investigação social, desde entrevistas e observações sistematizadas até o mapeamento de redes em mídias digitais.

Partimos da premissa de que as redes de atores sociais, como conjuntos de nós interconectados (CASTELLS, 1999), podem compreender tanto a articulação de movimentos sociais institucionalmente estabelecidos como a conexão de actantes ou grupos de actantes com interesses, referenciais ou mesmo elementos simbólicos comuns, como é o caso de parte significativa dos atores sociais elencados para viabilização deste estudo.

As redes formadas por esses actantes em ambientes digitais passam também a agir como mediadores das políticas públicas, dado que são dotadas da capacidade de traduzir e redefinir aquilo que transportam (LATOUR, 1994), constituindo-se como entidades estruturadas por associações e dissociações permanentemente tensionadas e permeadas por controvérsias (LATOUR, 2011; 2012).

Por participação social compreende-se a reivindicação do direito a ter direitos (DAGNINO, 2004a), o que implica em um processo reivindicatório de acesso aos processos políticos que estabelecem os próprios direitos, resultando na inserção dos indivíduos nas estruturas de poder que definem o contexto social. Trata-se da construção de uma nova sociabilidade que impõe um formato mais igualitário nas relações de poder entre sociedade e Estado, no fortalecimento da esfera pública e dos debates nela inseridos (REIS; PEIXOTO; MAKIUCHI, 2015).

Por fim, considerando a infinidade de conceitos para o termo cultura que, em geral abordam os conhecimentos, expressões, formas e valores transmitidos entre gerações, 
adotamos neste estudo o conceito de direito cultural, previsto na Declaração Universal dos Direitos Humanos e incluído na Constituição Federal Brasileira de 1988. Sob esse aspecto, entende-se como direito cultural o direito à identidade e à diversidade cultural (ou direito à memória e à proteção do patrimônio cultural); direito à participação na vida cultural (que inclui os direitos à livre criação, o livre acesso, à livre difusão e à livre participação nas decisões de política cultural); direito autoral e; direito/dever de cooperação cultural internacional (MATA MACHADO, 2011).

\subsection{DeSEnVolvimento democrático, Pluralismo e a política COMO AÇÃO PÚBLICA}

Modelos de desenvolvimento pautados no crescimento econômico exerceram e ainda exercem influência no imaginário de parte significativa dos formuladores de políticas públicas. Diversas correntes de pensamento têm demonstrado, no entanto, que os critérios de eficiência apresentados pela economia clássica, embora possibilitem aumentos de produtividade, "não promovem uma distribuição justa e equitativa dos benefícios econômicos provenientes desse aumento, especialmente se a estrutura socioeconômica revela frágeis indicadores das dimensões humana, social e de governança” (ENRÍQUEZ, 2010, p. 177-178).

A partir dos anos 1960, estudos sobre pobreza, equidade na distribuição de renda e desemprego passaram a integrar com mais força as teorias do desenvolvimento. Nessa corrente, o trabalho de Amartya Sen - ainda que dentro de certos limites - apresenta importantes contribuições em uma concepção de desenvolvimento como um processo de caráter dinâmico e transversal, incorporando diferentes dimensões das relações e capacidades humanas.

Para Sen (2000, p. 10), “o desenvolvimento consiste na eliminação de privações de liberdade que limitam as escolhas e as oportunidades das pessoas de exercer ponderadamente sua condição de agente", de forma que sua importância substantiva é suplementada pela eficácia instrumental de liberdades "cruciais", nas palavras do autor, incluindo-se nestas últimas as oportunidades econômicas, liberdades políticas, facilidades sociais, garantias de transparência e segurança protetora, em um sentido que passa a integrar a garantia e a promoção dos direitos de minorias políticas, de modo que cada 
sujeito seja visto como agente ativo de mudança e não como mero recebedor passivo de benefícios do Estado.

Em síntese, o exercício das liberdades funcionaria em um processo de retroalimentação. No exercício das liberdades políticas, por exemplo, os indivíduos participariam das decisões públicas fortalecendo os processos democráticos no sentido da melhor adequação às suas necessidades, baseadas em um conjunto de valores socialmente definidos que, por sua vez, possibilitariam o desenvolvimento de suas capacidades e eliminariam outras formas de privação de liberdade.

Percebe-se aí a centralidade dos valores democráticos na perspectiva do desenvolvimento como liberdade, abordagem com a qual trabalhamos em diversos momentos neste estudo, principalmente no que se refere à institucionalização das políticas culturais no Brasil e no mundo, tema do próximo capítulo. É preciso observar, no entanto, que ao analisar a participação social dentro de políticas públicas de cultura, cabe a atenção também a reflexões (RADOMSKY, 2011; MARTÍNEZ; DE ANGELIS, 2013) sobre a própria ideia de desenvolvimento, conceito historicamente carregado por um pensamento próprio da cultura etnocêntrica ocidental que, desde meados da década de 1950, vem sendo utilizado para fazer a distinção entre os países capitalistas ricos e as "áreas subdesenvolvidas", como dito pelo então presidente dos Estados Unidos, Harry Truman, em 1949, na ocasião de seu discurso de posse.

Elaborações teóricas - muitas delas descritas na onda que ficou conhecida no meio acadêmico como pós-desenvolvimentista - somam à discussão das liberdades humanas propostas como a de pensar alternativas para a modernidade, incluir a noção de bem viver no conceito de desenvolvimento (RADOWSKY, 2011) ou mesmo rejeitar o termo desenvolvimento, promovendo assim a descolonização do pensamento hegemônico e destacando também a valorização das soluções encontradas pelas diferentes comunidades locais (MARTÍNEZ; DE ANGELIS, 2013), entre outras contribuições voltadas sobretudo à sustentabilidade da ideia de desenvolvimento clássica para o planeta.

O reconhecimento da dimensão cultural das diferentes nações e dos diferentes territórios, bem como a institucionalização das políticas públicas de cultura a partir do período pós-guerra - sobre a qual trataremos no capítulo 2 desta dissertação -, revelaram novas perspectivas para o desenvolvimento dentro de uma concepção mais abrangente e compatível com os valores democráticos, o que inclui tanto as reflexões das liberdades e 
capacidades humanas como questionamentos sobre a sustentabilidade de projetos baseados nas teorias do crescimento econômico, sobre o saber institucionalizado na concepção de desenvolvimento que parte de um certo grupo de países e sobre a percepção do desenvolvimento como meta última de toda a sociedade (MARTÍNEZ; DE ANGELIS, 2013).

Ao ser compreendida como um direito, a cultura passa a adquirir um papel estratégico na construção de modelos de desenvolvimento com maiores possibilidades de garantir espaço à pluralidade, à diversidade e à convivência entre diferentes concepções de mundo, elementos fundamentais às sociedades democráticas contemporâneas.

O pluralismo, como defendido por Robert Dahl em seu Theory of Community Power (Teoria do Poder Comunitário), de 1958, propõe um olhar sobre o poder público para além da racionalidade de um grupo restrito de decisores, sugerindo ainda o exame da capacidade que a sociedade civil tem de influenciar as ações dos governos ou, como define Bobbio (1998), o pluralismo propõe como modelo a sociedade composta por vários grupos ou centros de poder aos quais é atribuída a função de limitar, controlar e contrastar o centro de poder dominante.

Tais premissas tornam-se especialmente relevantes na medida em que os sistemas políticos têm estado mergulhados em uma crise estrutural de legitimidade e a identidade está se tornando a principal fonte de significado "em um período histórico caracterizado pela ampla desestruturação das organizações, deslegitimação das instituições, enfraquecimento de importantes movimentos sociais e expressões culturais efêmeras" (CASTELLS, 1999, p. 41), enquanto as redes de intercâmbios instrumentais conectam e desconectam indivíduos e grupos em um fluxo continuo de decisões estratégicas, ou como diria Bauman (2001; 2010; 2013), é a própria modernidade líquida que vivemos, caracterizada pela fluidez e pelo estado de constante mudança.

A visão gerencialista e centralizadora acerca do papel do Estado já não faz sentido nesse panorama, cabendo a adoção de um conceito sobre a política que se aplique não apenas à atuação da administração estatal ou do poder público, no sentido convencional, mas também à de outros atores públicos e privados originários da sociedade civil, que agem em busca de objetivos comuns.

Sob esse aspecto, o modelo de política como ação pública proposto por Pierre Lascoumes e Patrick Le Galès (2012) compreende cinco elementos articulados entre si, 
como mostra a figura 1 .

Figura 1 - Pentágono das políticas públicas

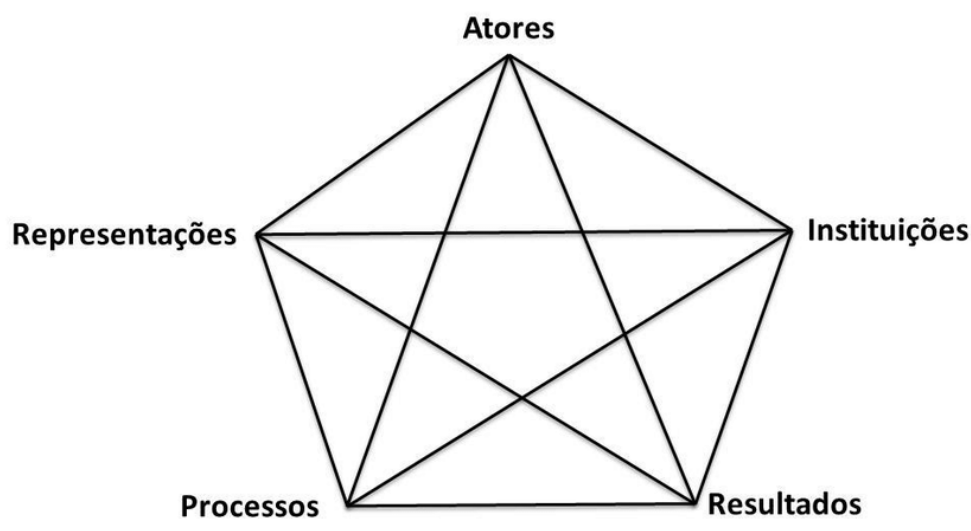

Fonte: LASCOUMES; LE GALÈS, 2012, p. 45.

Os atores, que podem ser individuais ou coletivos, são dotados de recursos, relativa autonomia, estratégias e capacidade de fazer escolhas; as representações são os espaços cognitivos e normativos que dão sentido às suas ações; as instituições são as normas, regras, rotinas, procedimentos que governam as interações; os processos são as formas de interação e sua recomposição no tempo e os resultados são as consequências ou os efeitos da ação pública.

Para os autores, a ação pública refere-se à interação entre esses elementos, seus jogos de normas e conflitos, sublinhando a política como uma construção coletiva. Os resultados são importantes nessa perspectiva como componentes da ação pública, assim como os demais aspectos e sua capacidade de responder aos problemas elencados pelos atores.

Em um nível ótimo, esses elementos trabalhariam no sentido de possibilitar modalidades e arranjos sociais compatíveis com os princípios democráticos, em um ambiente que é marcadamente concorrencial, como observaremos nas páginas seguintes nas quais abordamos reflexões das principais correntes teóricas da democracia contemporânea.

Ao propormos um estudo de caso sobre a participação de atores da sociedade civil articulados em rede para construção e controle das políticas públicas de cultura no Distrito Federal, considerando a noção de política como ação pública, buscamos observar a 
articulação entre os elementos expostos por Lascoumes e Le Galès, que reconhecem a necessidade de interpretação aberta dos desafios atrelados aos interesses concretos e simbólicos dos atores envolvidos, assimilando controvérsias e formas de resolução dos conflitos, de forma que a Teoria Ator-Rede (LATOUR, 2011; LATOUR, 2012) - sobre a qual trataremos no capítulo 3 - nos pareceu a abordagem metodológica mais adequada para esse fim ao sublinhar a dinâmica das interações nas redes.

Consideramos que as estruturas ou teias de relações que configuram esse novo modo de organização da sociedade civil moldam também dinâmicas associadas a sua relação com o Estado, não mais visto como o topo da hierarquia política, mas ainda como um importante elemento a ser analisado dentro de uma concepção democrática de gestão pública.

Analisaremos nas redes selecionadas neste estudo a articulação desses elementos, observando como os atores se relacionam entre si e com as instituições a partir de suas representações, como se dão os processos e que proximidade têm com os resultados das ações para analisar os fatores concorrentes e possíveis perspectivas para a participação social por meio da internet e dispositivos compatíveis, que atuam aqui na perspectiva de actante da Teoria Ator-Rede, tanto dentro dos cinco elementos do pentágono das políticas públicas como enquanto instrumentos da ação pública, ou seja, como componentes técnicos que tornam possível, no contexto da cibercultura, a execução dos projetos definidos pela interação de atores e demais elementos no jogo democrático.

\subsection{DELIBERAÇÃO E PARTICIPAÇÃO SOCIAL NA TEORIA DEMOCRÁTICA CONTEMPORÂNEA}

As dinâmicas de movimentos populares e atores sociais em diferentes partes do mundo pela abertura das possibilidades de ação de interesse coletivo têm recebido, nas últimas décadas, grande atenção de estudiosos e agentes políticos, configurando-se como algumas das mais inquietantes matérias de estudo dentro da teoria democrática contemporânea.

A palavra "participação" tornou-se parte do vocabulário político popular já nos últimos anos da década de 1960 (PATEMAN, 1992), reflexo da atuação de movimentos trabalhistas e estudantis de parte da Europa e dos Estados Unidos, ganhando força no final 
do século $\mathrm{XX}$ - sobretudo a partir de questionamentos quanto à estabilidade de um sistema participativo em larga escala - a chamada corrente deliberacionista e sua proposta de conferir aos cidadãos a oportunidade de decidirem racionalmente sobre os assuntos que lhes dizem respeito (SAMPAIO, 2012).

Expoentes do deliberacionismo, tanto a teoria da justiça como equidade, de John Rawls, como a teoria da ação comunicativa, de Jürgen Habermas, valem-se da razão pública para a organização das sociedades políticas, algo que propõem como alternativa ao modelo agregativo ${ }^{2}$ da democracia liberal até então dominante dentro da teoria política (MOUFFE, 2005).

Para os deliberacionistas, é preciso recuperar a dimensão moral da democracia e, no entendimento de Rawls, somente um consenso baseado no "equilíbrio reflexivo" (reflective equilibrium) ou na capacidade de um juízo ponderado entre casos particulares, de um lado, e um conjunto de princípios éticos e pressupostos teóricos, de outro - seria capaz de unir as diversas diretrizes privadas ou de fazer superar suas principais diferenças no sentido de conduzir as pessoas a deliberarem por ações que tornassem as sociedades democráticas mais justas.

Esse senso estaria fundamentado em uma "posição original" (original position) ou situação hipotética na qual cidadãos livres e iguais escolheriam sob um "véu de ignorância" (veil of ignorance) os princípios de justiça que deveriam governar a estrutura básica da sociedade. Esta, por sua vez, traduziria o modo pelo qual as instituições sociais, políticas e econômicas se estruturam sistematicamente para atribuir direitos e deveres aos cidadãos.

Ao analisar os conceitos deliberacionistas para mais tarde vir a propor um modelo "agonístico" de democracia, Chantal Mouffe destaca o caráter normativo dessa corrente, observando que tanto em Rawls como em Habermas a racionalidade supera o nível instrumental ao estabelecer uma separação entre o mero acordo - como exposto no modelo agregativo - e o consenso racional. Se a concepção de Rawls enuncia a importância dos elementos constitucionais essenciais para a razão pública livre, em Habermas tem-se a

2 O modelo agregativo, também conhecido no meio acadêmico como teoria política empírica, teve início com o trabalho de Joseph Schumpeter, de 1947, Capitalism, Socialism and Democracy, e propunha ênfase das democracias de massa na agregação de preferências, disposta por meio de partidos políticos e eleições regulares, sendo desencorajada a participação popular na tomada de decisões em benefício da estabilidade do sistema. 
defesa de que "são os constrangimentos procedimentais da situação ideal de fala que eliminarão as posições que não podem ser aceitas pelos participantes do discurso moral" (MOUFFE, 2005, p. 14).

Nessa perspectiva, o propósito do procedimento democrático seria o de gerar "poder comunicativo", o que requer o estabelecimento de condições para o livre consentimento de todos os envolvidos, como normas de igualdade e simetria nos debates, possibilidade de questionamento para todos e o direito de iniciar argumentos reflexivos sobre as próprias regras do procedimento discursivo.

A opinião pública pretende corresponder à "natureza das coisas". Por isso, "leis" que ela agora gostaria que também fossem válidas para a esfera social, precisam assegurar-se, além dos critérios formais de generalidade e abstrações, também da racionalidade como um critério material. (HABERMAS, 1984, p.72)

Esse exercício de auto-organização da sociedade pelos cidadãos seria capaz de emprestar força legitimadora ao processo político, e a "esfera pública" teria o poder de reforçar a pressão exercida pelos problemas, não se limitando a percebê-los e identificálos, mas devendo também tematizá-los, problematizá-los e dramatizá-los de modo convincente e eficaz, a ponto de serem assumidos e elaborados pelas autoridades públicas (HABERMAS, 1992, p. 432-433 apud LUBENOW, 2010, p. 235).

Vale destacar que, para Habermas, a esfera pública é uma estrutura que faz a mediação entre Estado, sistema político e os setores privados do mundo da vida, sendo dotada de um sistema de sensores e vindo a filtrar e sintetizar temas, argumentos e contribuições, transportando-os posteriormente para o nível dos processos institucionalizados de resolução e decisão.

\begin{abstract}
A esfera pública burguesa pode ser entendida inicialmente como a esfera das pessoas privadas reunidas em um público; elas reivindicam esta esfera pública regulamentada pela autoridade, a fim de discutir com ela as leis gerais da troca na esfera fundamentalmente privada, mas publicamente relevante, as leis do intercâmbio de mercadorias e do trabalho social. (HABERMAS, 1984, p. 42)
\end{abstract}

Oliveira (2003) destaca que as contribuições de autores como Rawls e Habermas mostram sobretudo que o procedimentalismo deve ser complementado pela ideia normativa de uma razão pública concebida em termos democrático-constitucionais. No 
entanto, ele mesmo chama atenção para suas limitações diante do fato de que os indivíduos e suas instituições não podem ser considerados isoladamente. Essa constatação representa um desafio importante para a democracia e para a teoria deliberativa, materializada por exemplo nos casos de posturas intransigentes e de grupos radicais que ganham destaque nos cenários brasileiro e internacional ou mesmo nas disputas de projeto político nos diversos sistemas políticos.

\begin{abstract}
Mesmo que se idealizasse uma concepção universalizável de cultura política, o que se tem hoje é uma proposta democrático-liberal que, apesar de todas as deficiências em sua gênese histórico-conceitual (colonialismo e póscolonialismo), ainda se apresenta como a mais viável para todas as nações, inclusive para as que ainda não têm valores democráticos sedimentados em seu ethos sociopolítico. Assim, as liberdades básicas e os direitos fundamentais - a começar pelo direito a saúde, educação e trabalho -, apesar de "garantidos" pela constituição de muitos países, devem ser efetivamente reivindicados pela sociedade civil, mesmo em se tratando de questões que envolvem discussões técnicas, especificamente pertinentes ao governo e aos três poderes em seus variados níveis de representatividade. (OLIVEIRA, 2003, p. 45)
\end{abstract}

Percebe-se aí a sutil nuance entre os modelos de democracia deliberativa e participativa que, não em raras oportunidades, vêm a complementar-se, como observa Carole Pateman:

A existência de instituições representativas a nível nacional não basta para a democracia; pois o máximo de participação de todas as pessoas, a socialização ou "treinamento social", precisa ocorrer em outras esferas, de modo que as atitudes e qualidades psicológicas necessárias possam se desenvolver. Esse desenvolvimento ocorre por meio do próprio processo de participação. (PATEMAN, 1992, p. 60)

A cientista faz uma defesa da participação a partir de sua função educativa, apresentando-a como parte do processo de formação política. Segundo ela, para que os indivíduos exerçam o máximo controle sobre suas próprias vidas e sobre o ambiente - um pressuposto do modelo de democracia liberal -, as estruturas de autoridade nessas áreas precisam ser organizadas de tal forma que eles possam participar das decisões ${ }^{3}$.

3 Um exemplo interessante do argumento de Pateman sobre a relação entre a participação e o processo educativo que a viabiliza pode ser encontrado no movimento zapatista que ganhou destaque mundial a partir da década de 1990 quando se manifestaram contra o NAFTA (acordo de livre comércio entre México, Estados Unidos e Canadá) que foi criado na mesma data. Inspirado na luta de Emiliano Zapata contra o regime autocrático de Porfirio Díaz que encadeou a Revolução Mexicana em 1910, os zapatistas 
Pateman advoga pelo modelo participativo muitas vezes como viabilizador da democracia nos moldes contemporâneos, caracterizando-o como aquele onde se exige a “entrada" (input) ou participação máxima e onde a "saída" (output) inclui não apenas as políticas (decisões), mas também o desenvolvimento das capacidades sociais e políticas de cada indivíduo, de forma que o resultado seja uma real experiência de retroalimentação (feedback) de saída e entrada (PATEMAN, 1992).

Diana C. Mutz (2006) segue outra linha de pensamento e argumenta que a participação acaba por apresentar senão um novo desafio à democracia. Em seu Hearing the other side: deliberative versus participatory democracy, a pesquisadora discorre sobre resultados de estudos empíricos realizados nos Estados Unidos que apontam as dificuldades para conciliar as propostas do modelo participativo focado na ação política, na capacidade de empatia e no estabelecimento de causas comuns com as premissas do modelo deliberativo, que busca a racionalização de diferentes valores e pontos de vista.

Entre outros resultados, as pesquisas elencadas por Mutz apontam que a maioria dos cidadãos dos Estados Unidos não tem um parceiro de conversa regular com diferente posicionamento político, não sabendo por exemplo nomear um número mínimo de pessoas com pensamento divergente com as quais discutem política. Os estudos mostram ainda que aqueles que têm redes maiores e mais densas de discussão são aqueles que menos experimentam diversidade nas suas conversações políticas, além de que as redes com mais opiniões diferentes apresentam menor probabilidade de se efetivar em consistente pressão social para tomada de ação.

\footnotetext{
Estudos de redes sociais têm sugerido há muito tempo que "curtidas conversam com curtidas" [likes talk to likes]; em outras palavras, as pessoas tendem a se expor seletivamente a outras que não desafiam sua visão do mundo. Pesquisas atrás pesquisas mostram que as pessoas falam mais com aqueles que têm afinidade que com aqueles que não, e questões políticas não são exceção a este padrão geral. Além disso, muitas pessoas não têm muito desejo de participar do debate político para começar, mesmo a variedade informal. A exposição a diversos pontos de vista políticos pode ser amplamente defendida em teoria, mas é muito menos popular na prática real. Nesse sentido, a medida em que as pessoas estão expostas a pontos de vista oposicionistas demonstra alguns dos mesmos padrões que a exposição à diversidade em outras dimensões, como raça e classe. Embora a diversidade seja um objetivo público muito elogiado no
}

defendem uma gestão autônoma e democrática do território, a participação direta da população nesse processo, bem como a partilha da terra e da colheita. 
agregado, poucos indivíduos vivem suas vidas cotidianas de modo a maximizar sua exposição à diferença. (MUTZ, 2006, p. 9-10, tradução nossa ${ }^{4}$ )

Chantal Mouffe apresenta sua proposta do pluralismo agonístico partindo de concepção similar, ao ressaltar que "o domínio da política - mesmo quando questões básicas como justiça ou princípios fundamentais estão envolvidos - não é um terreno neutro que poderia ser isolado do pluralismo de valores ou em que soluções racionais e universais poderiam ser formuladas" (MOUFFE, 2005, p. 16).

A autora observa que o que realmente está em jogo na fidelidade a instituições democráticas é a constituição de um conjunto de práticas que façam possível a criação de cidadãos democráticos e que isso não seria somente uma questão de "justificação racional", como argumentam os democratas deliberativos, mas de "disponibilidade" de formas democráticas de individualidade e subjetividade. Para ela, as teorias democráticas contemporâneas deixam de lado um elemento importante da política: o papel desempenhado por paixões e afetos na garantia da fidelidade a valores democráticos, faltando a essas abordagens reflexões mais profundas sobre quais são as condições de existência do sujeito democrático, onde se poderia incluir as relações sociais e de poder, linguagem, cultura e o conjunto de práticas que tornam a ação pública possível.

$\mathrm{Na}$ ótica do pluralismo agonístico, há uma clara distinção entre "o político" e "a política", sendo o primeiro a "dimensão do antagonismo inerente às relações humanas" e a segunda "o conjunto de práticas, discursos e instituições que procuram estabelecer uma certa ordem e organizar a coexistência humana em condições que são sempre conflituais porque são sempre afetadas pela dimensão do político” (MOUFFE, 2005, p. 20).

Nesse sentido, o propósito da política democrática seria construir bases para a ação nas quais os indivíduos não se encarassem como inimigos a serem destruídos, mas como adversários cujas ideias devem ser combatidas, porém sem questionamentos quanto ao

4 Texto original: Social network studies have long suggested that likes talk to likes; in other words, people tend to selectively expose themselves to people who do not challenge their view of the world. Network survey after network survey has shown that people talk more do whose who are like them to those who are not, and political agreement is no exception to this general pattern. Moreover, many people do not have much desire to engage in political debate to begin with, even the informal variety. Exposure to diverse political viewpoints may be widely advocated in theory, but it is much less popular in actual practice. In this sense, the extent to which people are exposed to oppositional views demonstrates some of the same patterns as exposure to diversity along other dimensions, such as race and class. While diversity is a much-lauded public goal in the aggregate, few individual people live their everyday lives só as to maximize their exposure to difference. 
direito que têm de defendê-las.

É também o que destaca Alain Touraine, ao sublinhar que "o regime democrático é a forma de vida política que dá maior liberdade ao maior número, que protege e reconhece a maior diversidade possível” (TOURAINE, 2001, p. 7, tradução nossa ${ }^{5}$ ). Ressalta assim a necessidade de observar os atores sociais e suas dinâmicas, uma vez que eles podem demonstrar a consciência do que têm em comum e dos mecanismos de conflitos e interesses particulares que os definem uns contra os outros (TOURAINE, 2006), algo que exploramos neste estudo a partir da abordagem metodológica da Teoria Ator-Rede e de seu olhar sobre os lastros deixados pela interação.

No Brasil, a criação de espaços públicos e a crescente participação da sociedade civil nos canais de discussão e tomada de decisão - desde a redemocratização e sobretudo após a Constituição de 1988 - caracterizou também um "processo de encolhimento do Estado e de progressiva transferência de suas responsabilidades sociais para a sociedade civil” (DAGNINO, 2004, p. 198).

À medida que o envolvimento da sociedade civil nas políticas sociais aumentou, uma questão tornou-se pujante: o surgimento de novas formas de representação ligadas a ela. Nesse sentido, "o Estado passou a lidar institucionalmente com uma representação oficial da sociedade civil" (AVRITZER, 2007, p. 444), gerando um processo de superposição de representações.

Essa marcha conferiu aos movimentos sociais, membros de organizações não governamentais (ONGs), integrantes de conselhos gestores e outros "representantes" deste segmento o papel de "interlocutores", na medida em que coube a eles a expressão dos interesses difusos da sociedade à qual "dariam voz" nas relações com o Estado (DAGNINO, 2004).

Com o amadurecimento democrático do Estado brasileiro, esse arranjo institucionalizado e formal da participação social passou a receber questionamentos, advindos sobretudo da falta de clareza quanto às intenções e escolha dos participantes, da tensão entre os princípios da autonomia e da eficácia política de atuação da sociedade civil

5 Texto original: El régimen democrático es la forma de vida política que da la mayor libertad al mayor número, que protege y reconoce la mayor diversidad posible. 
"por dentro do Estado" e da instrumentalização das relações entre sociedade civil e sociedade política que parecia enfraquecer os potenciais de mudança, dado que "os movimentos passariam a atuar muito mais como demandantes de bens e serviços (e a serem assim reconhecidos), do que como atores que oferecem à sociedade novas formas de nomeação da realidade, a partir do exercício de sua função crítica" (TATAGIBA, 2010, p. 71-72).

As iniciativas digitais ganham força nesse contexto sobretudo pela perspectiva de abertura do debate e da ação no jogo democrático para além das instâncias formais e já reconhecidas dentro do Estado, uma vez que ferramentas online se mostram cada vez mais capazes de organizar, armazenar e expor informação de interesse geral em larga escala para grandes contingentes de cidadãos.

Relatório da União Internacional de Telecomunicações (UIT, 2015) aponta que entre os anos 2000 e 2015, a penetração da Internet aumentou quase sete vezes, de 6,5\% para $43 \%$ da população global. Em 15 anos, o número de usuários de internet passou de 400 milhões para 3,2 bilhões e a proporção de domicílios com acesso à Internet em casa avançou para quase $46 \%$.

Um número razoavelmente amplo de pesquisas conduzidas nos últimos anos tem mostrado indícios de que as mídias digitais possibilitam uma atuação política diferente daquela operacionalizada sob a lógica tradicional, propiciando condições para a ocorrência de fenômenos como maior interatividade entre agentes institucionais e cidadãos, liberdade de discurso e publicação instantânea de conteúdos a baixo custo (MAIA; GOMES; MARQUES, 2011). Essa dinâmica é analisada neste estudo não apenas a partir das possibilidades que abre, mas também a partir dos fatores que concorrem para sua efetivação no âmbito da ação pública, da participação social e da deliberação, sendo relevante a contextualização sobre os conceitos de redes sociais, democracia digital e cibercultura, reflexões que abordamos nas páginas seguintes.

\subsection{REDES SOCIAIS, DEMOCRACIA DIGITAL E CIBERCULTURA}

Desde o início dos anos 2000, organizações internacionais como a Organização das 
Nações Unidas (ONU) e a Organização para a Cooperação e Desenvolvimento Econômico (OCDE) têm monitorado o que vêm chamando de E-participation Index - índice no qual a ONU trata da participação social através de ferramentas e dispositivos compatíveis com a internet - e E-democracy - em um sentido mais amplo, que veio a ser adotado pela OCDE. Ambos tentam categorizar elementos para avaliação do uso da internet para fins de fortalecimento democrático, seguindo propósitos tais como o fortalecimento da capacidade concorrencial da cidadania (aumento da transparência do Estado e formas de responsabilização dos agentes políticos ou incremento da participação e influência civis); a consolidação e o reforço de uma sociedade de direitos e a promoção do pluralismo e da capacidade concorrencial das minorias (MAIA; GOMES; MARQUES, 2011).

O esforço dessas organizações e estudiosos da democracia segue as provocações levantadas pelo cenário resultante da chamada "Era da informação", que tem suas bases em diversas invenções do início do século XX, mas é verdadeiramente inaugurada na década de 1970, com a criação da internet e a expansão das demais tecnologias de informação e comunicação.

Diferente de outros movimentos, a revolução das TICs ocorreu de forma global, ou seja, não ficou contida em apenas uma região ou grupo de países, mas se espalhou pelo mundo de maneira nunca antes vista, promovendo mudanças das mais diversas ordens, sobretudo em termos culturais.

A internet surgiu como uma rede de computadores conectados entre si, sendo desenvolvida pela Agência de Projetos de Pesquisa Avançada (ARPA) do Departamento de Defesa do Estados Unidos, durante a década de 1960, com o objetivo de montar um sistema de comunicação que não pudesse ser destruído durante um ataque nuclear.

Precursora da grande rede mundial de computadores, a ARPANET entrou no ar em $1^{\circ}$ de setembro de 1969, ligando quatro das maiores universidades dos Estados Unidos: Universidade da Califórnia em Los Angeles, Stanford Research Institute, Universidade da Califórnia em Santa Bárbara e Universidade de Utah, estando desde o início ligada ao meio acadêmico que, observando suas potencialidades, superou o uso militar, utilizando a rede, já em seus primórdios, para a troca de mensagens e arquivos, bem como para a produção de conhecimento.

Com a criação da World Wide Web, em 1990, a internet começou efetivamente a sua incursão pelo mundo. Uma equipe de pesquisadores do Centro Europeu de Pesquisas 
Nucleares (CERN), chefiada por Tim Berners Lee, criou o "www" como forma de organizar as informações pelo conteúdo, e não mais por sua localização, tornando muito mais fácil encontrar conteúdo na rede de computadores interligados. A equipe de Lee foi responsável pela criação dos termos mais conhecidos atualmente da internet e que permitem a fácil navegação, como a linguagem de programação HTML (para o desenho de páginas) e o $U R L$ (o endereço específico de cada sítio na internet), sendo que, em 1994, com a criação dos primeiros navegadores comerciais, tem-se "a alavanca final para o começo da hegemonia da internet" (NOGUEIRA, 2014, p. 16).

A partir dos anos 2000, ocorre uma nova mudança de paradigma na internet: o surgimento da Web 2.0. Enquanto em seu surgimento os serviços online incentivavam o download (opção de salvar determinado conteúdo em um dispositivo com acesso a internet), a Web 2.0 investiu em serviços totalmente online, com softwares que funcionassem em diversas plataformas, desde computadores a celulares e tablets. Esses novos serviços baseavam-se também na construção colaborativa de novas soluções, funcionalidades e interações, dando início ao protagonismo das redes sociais virtuais.

Já se fala no entanto que o uso massivo das redes sociais vem promovendo uma terceira mudança de paradigma, a Web 3.0, focada em interpretar o grande número de dados disponíveis (big data) para gerar soluções cada vez mais de acordo com o que as pessoas desejam, como os serviços de busca que vão sendo refinados à medida que o usuário utiliza, e uma tendência de que os indivíduos e as organizações desenvolvam perfis online para interagir em múltiplas plataformas, como usar seu perfil em determinada rede social virtual para acessar diversos serviços, como sites de notícias e compra de produtos online, bem como aplicativos dos mais variados tipos, desde ferramentas para paquera online a dispositivos para monitoramento do comportamento focados em saúde e bem estar (PAIVA, 2010).

Esse movimento, do ponto de vista social, redefine as próprias bases da “cibercultura”, no conceito de Lévy (1999, p. 16), que a caracteriza como "o conjunto de técnicas (materiais e intelectuais), de práticas, de atitudes, de modos de pensamento e de valores que se desenvolvem juntamente com o crescimento do ciberespaço".

O autor chama atenção para comportamentos cada vez mais comuns nas sociedades contemporâneas, como o de conservar, sob forma numérica e registrada na memória de dispositivos eletrônicos, textos, imagens e outros conteúdos, que passam a ser 
compartilhados em uma velocidade sem precedentes.

Entre tantos fatores, um dos que mais impressiona no ciberespaço é a agilidade com que as novas tecnologias, dispositivos de conexão em rede, suas ferramentas e conteúdos produzidos se propagam ${ }^{6}$. Se o telefone levou aproximadamente 70 anos para atingir a marca de 50 milhões de usuários, o rádio precisou de 38 anos e a televisão, 13, a internet levou menos de 5 anos para atingir o mesmo patamar. As redes sociais virtuais aceleraram ainda mais estas transformações, e o Facebook ${ }^{7}$, plataforma selecionada para o desenvolvimento deste estudo, atingiu mais de 100 milhões de usuários em apenas 9 meses.

Para Lévy, o crescimento do espaço cibernético ou ciberespaço ${ }^{8}$ é orientado por três princípios fundamentais: a interconexão, a inteligência coletiva e a criação de comunidades virtuais. A interconexão ocorre na medida em que a dinâmica nesse ambiente é basicamente dialógica, ampliando as possibilidades de interação, onde ganha-se plasticidade e tem-se a possibilidade da metamorfose imediata, de modo que "cada pessoa pode se tornar uma emissora, o que obviamente não é o caso de uma mídia como a imprensa ou a televisão" (LÉVY, 2010, p. 95).

Nesse sentido, os indivíduos tornam-se parte integrante do processo de criação, transformação e divulgação da informação (MACHUY, 2016), como destaca Lévy, ao ressaltar que o ciberespaço introduz a ideia de que toda leitura é uma escrita em potencial:

6 Fonte: Revista Superinteressante. São Paulo: Editora Abril, março de 2011. Disponível em: <http://super.abril.com.br/tecnologia/sociedade-informacao-442036.shtml>. Acesso em 06 mar. 2017.

7 Facebook é uma rede social virtual lançada em 2004 e fundada por Mark Zuckerberg, Eduardo Saverin, Andrew McCollum, Dustin Moskovitz e Chris Hughes, então estudantes da Universidade Harvard., nos Estados Unidos Trata-se de uma plataforma de acesso gratuito para os usuários que gera a maior parte de sua receita a partir de publicidade e propaganda. Os usuários criam perfis que contêm fotos e listas de interesses pessoais, trocando mensagens e conteúdos multimídia entre participantes de páginas (ou fanpages), grupos de interesse e redes privadas. O Facebook possui várias ferramentas, como o mural, linha do tempo ou timeline, que é um espaço central na página de perfil do usuário ou das fanpages, sendo estas últimas uma espécie de perfil mais voltado a organizações no qual é necessário demonstrar interesse de "seguir" as publicações a partir da opção de "curtir" determinada página. O mural é visível para qualquer pessoa com permissão para ver o perfil ou a página completa, e posts diferentes de outros usuários ou fanpages aparecem separados no "Feed de Notícias", que reúne as diferentes publicações de usuários da rede, dando maior ou menor impulso e alcance aos conteúdos a partir da organização de algoritmos.

8 O termo ciberespaço foi cunhado pela primeira vez em 1984 no romance "Neuromancer", do autor norteamericano William Gibson. Na obra, o ciberespaço é descrito como um lugar não físico ou desterritorializado, onde se vai com a mente, catapultado pela tecnologia, enquanto o corpo físico fica para trás. Sob esse aspecto, o conceito de virtual, atrelado à ideia do espaço cibernético não se opõe ao real nem ao material. Ainda que não esteja fixo em ampla coordenada de tempo e espaço, o virtual existe no espaço do dispositivo em que pode ser acessado. 
O que há em comum em todas as bases nos bancos de dados do espaço cibernético? Não são as mensagens fixas, mas um potencial de mensagens e que, dependendo de quem vai utilizá-los, vai para uma direção ou outra. O que acontece é que, com isso, se recupera a possibilidade de ligação com um contexto que tinha desaparecido com a escrita e com todos os suportes estáticos de formação. É possível através disso reencontrar uma comunicação viva da oralidade, só que, evidentemente, de uma maneira infinitamente mais ampliada e complexificada. Por exemplo, é isto que observamos com o que acontece, hoje, com o hipertexto ou multimídia interativa. (LÉVY, 1994, p. 1-2)

A inteligência coletiva, por sua vez, descreve um tipo de inteligência compartilhada que surge da colaboração de muitos indivíduos em suas diversidades, uma vez que ninguém sabe tudo, mas todos sabem alguma coisa. É o que orienta, por exemplo, a filosofia wiki e plataformas de enciclopédias livres como a Wikipédia (MACHUY, 2016), na qual todo conteúdo é produzido de maneira coletiva pelos usuários.

Essa dinâmica é integrada ao princípio de criação de comunidades virtuais, que seriam então "construídas sobre afinidades de interesses e conhecimento, em um processo mútuo de cooperação e troca" (LÉVY, 1999, p.127) ou formação de redes, como um conjunto de nós conectados (CASTELLS, 1999).

A organização em rede não é novidade na história humana, mas sim como abordagem sociológica (RECUERO, 2008). O que caracteriza e torna único esse movimento da "Era da informação" é a utilização das TICs, que aceleraram o tempo e expandiram o espaço em que as conexões podem ser feitas. Ou como defende Castells (2012):

\footnotetext{
É uma sociedade em que as atividades principais nas quais as pessoas estão engajadas são organizadas fundamentalmente em rede, ao invés de em estruturas verticais. O que faz a diferença são as tecnologias de rede. Uma coisa é estar constantemente interagindo com pessoas na velocidade da luz, outra é simplesmente ter uma rede de amigos e pessoas. Existe todo tipo de rede, mas a conexão entre todas elas - sejam os mercados financeiros, a política, a cultura, a mídia, as comunicações etc. -, é nova por causa das tecnologias digitais. (CASTELLS. Entrevista concedida a Paul Mason e publicada na Revista Fórum Online em 28 de novembro de 2012. Disponível em: $<$ http://revistaforum.com.br/blog/2012/11/castells-ve-expansao-do-naocapitalismo/>. Acesso em 06 mar. 2017.)
}

As redes sociais virtuais são, portanto, a organização em rede por meio da internet e de outras tecnologias da informação. Essas redes são o coração das comunidades virtuais (como descritas por Lévy) e das mídias digitais, que por sua vez são a plataforma online para o funcionamento das redes sociais virtuais. 
Marcadas por traços como penetrabilidade, descentralização multifacetada e flexibilidade (RECUERO, 2009), as redes sociais virtuais acentuam também outros elementos importantes da cibercultura (JENKINS, 2009), como a possibilidade de segmentação (ou seja, as pessoas vão sendo movidas no sentido de buscar e ter à disposição seus conteúdos de interesse) e a convergência dos conteúdos que agora fluem por diversos canais, dado que podem ser produzidos e consumidos em qualquer lugar e a qualquer hora, sobretudo com os constantes avanços de ferramentas oferecidas por dispositivos móveis, como laptops e smartphones.

É o chamado "crowdsoursing” ou a construção por meio da multidão, uma nova dinâmica para relação entre as pessoas, a economia e os arranjos políticos, ou como observa Giardelli (2012, p. 20) “estamos começando a viver a era da participação e do compartilhamento, em que o que é trocado por pessoas de todo o planeta, levará a aldeia global $^{9}$ a outro patamar".

Para Castells (1999, p. 108), “a morfologia de rede parece estar bem adaptada à crescente complexidade de interação e aos modelos imprevisíveis de desenvolvimento derivado do poder criativo dessa interação", ou seja, "essa configuração pode ser implementada materialmente em todos os tipos de processos e organizações graças a recentes tecnologias ${ }^{10}$ da informação", sendo uma lógica necessária para "estruturar o nãoestruturado", mas preservando a flexibilidade, "pois o não-estruturado é a força motriz da inovação na atividade humana", observa o autor.

\begin{abstract}
Ademais, quando as redes se difundem, seu crescimento se torna exponencial, pois as vantagens de estar na rede crescem exponencialmente, graças ao número maior de conexões, e o custo cresce em padrão linear. Além disso, a penalidade por estar fora da rede aumenta com o crescimento da rede em razão do número em declínio de oportunidades de alcançar outros elementos fora da rede. (Idem)
\end{abstract}

Nesse sentido, no que se refere às redes de participação social que serão analisadas neste estudo, avaliaremos o grau de interação entre as redes de atores da sociedade civil e

9 "Aldeia global" é um termo cunhado pelo filósofo canadense Herbert Marshall McLuhan, com o intuito de indicar que as novas tecnologias de comunicação eletrônicas tendem a encurtar distâncias, de modo que todo o planeta poderia ser comparado a uma grande comunidade.

10 Manuel Castells (1999, p. 67) adota conceito similar ao de Harvey Brooks e Daniel Bell para o termo "tecnologia", entendendo que a mesma se refere ao uso de conhecimentos científicos para especificar as vias de se fazerem as coisas de uma maneira reproduzível, incluindo entre as tecnologias da informação "o conjunto convergente de tecnologias em microeletrônica, computação (software e hardware), telecomunicações/radiodifusão, e optoeletrônica". 
as redes de entes estatais, além da relação dos atores sociais com as próprias redes sociais digitais. Esse movimento, como explicitaremos no capítulo 3, foi observado a partir do mapeamento das redes de discussão de políticas públicas de cultura do Distrito Federal na plataforma Facebook, de forma que os resultados apontaram percepções interessantes às nossas perguntas de pesquisa, sobretudo no questionamento quanto aos fatores concorrentes para efetivação da participação social pela internet.

Apresentaremos mais detalhadamente em nosso percurso metodológico a opção pela análise de fanpages na plataforma Facebook, mas cabe aqui ressaltar uma observação que nos parece interessante quanto ao contexto do ciberespaço. Os sites de rede social, como o Facebook, têm conseguido uma adesão nunca antes registrada nos estudos em comunicação, estruturando-se como espaços vivos que conectam todas as dimensões da vida, ou como destaca Castells (2013):

\begin{abstract}
A atividade mais importante da internet hoje se dá por meio dos sites de rede social (SNS, de Social Networking Sites), e estes se tornam plataformas para todos os tipos de atividade, não apenas para amizades ou bate-papos pessoais, mas para marketing, e-commerce, educação, criatividade cultural, distribuição de mídia e entretenimento, aplicações de saúde e, sim, ativismo sociopolítico [...]. Temos agora um mundo permanentemente em rede em cada dimensão da experiência humana. As pessoas em suas redes evoluem conjuntamente em interações múltiplas e constantes. Mas elas escolhem os termos de sua coevolução. Os SNS são construídos pelos próprios usuários a partir de critérios de combinação específicos e de redes de amizade mais amplas, projetadas por pessoas, com base em plataformas fornecidas por empresários da comunicação livre, com diferentes níveis de constituição de perfis e de privacidade. (Idem, p. 169)
\end{abstract}

Nessa imersão dos diversos aspectos da vida no mundo digital, busca-se cada vez mais o compartilhamento de princípios antes restritos a indivíduos e pequenos grupos ou comunidades, de modo que as redes articuladas a partir do ambiente digital vêm reconstruindo a esfera pública, ao buscar a interface entre as práticas políticas, instituições e aspectos da experiência diária, e reconhecendo as diretrizes que se anunciaram nos modelos clássicos da democracia grega e foram resgatados nas revoluções libertárias do Iluminismo, "embora distingam a permanente traição desses princípios, a começar pela negação original da cidadania plena para mulheres, minorias e povos colonizados" (CASTELLS, 2013, p. 177).

É evidente que as democracias atuais estão longe da concepção grega do exercício de democracia direta dos cidadãos nas decisões da polis - até então restritas a homens 
livres, originários de certos lugares e dentro de determinada faixa etária, o que obviamente não tem se mostrado possível nas sociedades contemporâneas de grandes Estados nacionais e com grandes populações - e que a democracia representativa, nos moldes liberais, tem se mostrado a opção mais viável até o momento.

No entanto, como destaca Mouffe (2005, p. 11), embora a democracia liberal pareça ser reconhecida como a única forma legítima de governo na atualidade, "um número crescente de pessoas vem sentindo que os partidos tradicionais deixaram de atender a seus interesses e partidos de extrema-direita estão fazendo importantes incursões em muitos países". A cientista faz um reexame do debate contemporâneo em teoria democrática a partir dos diferentes modelos de democracia para propor seu modelo de pluralismo agonístico que enfatiza a importância de reconhecimento da dimensão conflitual na democracia.

Pereira da Silva segue na mesma linha, ressaltando que:

\begin{abstract}
Embora a necessidade de incorporar a opinião do cidadão na decisão política seja uma exigência clássica na história da democracia, na era moderna isso se tornou bastante complexo devido à ênfase dada ao mecanismo da representação. $\mathrm{Na}$ democracia representativa, o Estado está suscetível à opinião pública basicamente através de dois meios: 1) através da influência do cidadão sobre os seus representantes (isto é, de modo indireto, através de processos eleitorais, lobby, grupos de pressão etc., pois quem de fato vai decidir sobre os temas será o representante eleito); 2) através da incidência do cidadão no processo de decisão política em si (ou seja, de modo direto, principalmente via mecanismos plebiscitários nos quais a decisão é posta diretamente para votação do cidadão, sem intermediários). (SILVA In: MAIA; GOMES; MARQUES, 2011, p. 132)
\end{abstract}

Estudiosos contemporâneos tentam organizar referências para análise empírica dos dispositivos oferecidos pela internet quanto ao seu potencial de fortalecimento democrático e começam a surgir pesquisas que tentam aplicar modelos de análise a espaços já em desenvolvimento no país. Um desses modelos é proposto pelo cientista social Rafael Cardoso Sampaio e refere-se à apreensão deliberativa online (MAIA, R. C. M; GOMES, Wilson; MARQUES, F. P. J. A., 2011; SAMPAIO, 2012; SAMPAIO; BARROS; MORAIS, 2012), unindo conceitos e indicadores analíticos de diversos autores, que abordam desde o processo discursivo da esfera pública a elementos ligados ao contexto cultural, posicionamento dos atores envolvidos e estrutura das ferramentas digitais de comunicação.

Enquanto a maior parte dos modelos parecem centrar-se em sites governamentais e portais oficiais na internet, o modelo de Sampaio permite a aplicação também a outros canais de comunicação cidadã que não se refiram necessariamente a instituições formais e 
centralizadas de poder. Seria o caso, por exemplo, da articulação de redes de atores da sociedade civil para fins de participação nas decisões de interesse coletivo, uma forma de organização social que tem ganhado destaque em várias partes do mundo nos últimos anos, como na Revolução das Panelas na Islândia, nas Insurreições Árabes, no episódio dos Indignados na Espanha, no Occupy Wall Street, e nas Manifestações \#VemPraRua no Brasil em 2013 $)^{11}$, nas quais as redes digitais tiveram papel fundamental, como destaca Castells:

\begin{abstract}
Embora os movimentos tenham em geral sua base no espaço urbano, mediante ocupações e manifestações de rua, sua existência contínua tem lugar no espaço livre da internet. Por serem uma rede de redes, eles podem dar-se ao luxo de não ter um centro identificável, mas ainda assim garantir as funções de coordenação, e também de deliberação, pelo inter-relacionamento de múltiplos núcleos. (CASTELLS, 2013, p. 160)
\end{abstract}

Carole Pateman (1992) advoga por uma socialização e uma cultura da participação em todas as esferas da sociedade, dado que, para a cientista, o indivíduo só se realiza politicamente quando se sente parte e é incluído em todo o processo de formação política e não apenas na escolha de representantes em gabinetes e parlamentos.

As novas tecnologias, nesse sentido, se apresentam como um caminho para a efetivação da experiência democrática participativa (GOMES, 2005; SOUSA, 2008; GAROSSINI, 2010) ou pelo menos como ferramentas para potencializar maior atenção do Estado às demandas da população.

É a necessidade de formar novas categorias para explicar as profundas transformações que se apresentam na arena política da Sociedade da Informação. A relação de poder entre os atores, nesta realidade, está vulnerável a drásticas mudanças. (GAROSSINI, 2012, p.90)

Com o reconhecimento desse novo contexto e o crescimento do número de iniciativas voltadas à interface entre sociedade civil e Estado, sobretudo a partir dos anos 2000, o termo democracia digital e outros verbetes, como ciberdemocracia, democracia virtual ou e-democracia (atribuindo-lhe a inserção em contexto eletrônico) passaram a ser amplamente empregados por estudiosos, atores políticos e organismos internacionais para identificar o conjunto de práticas democráticas que utilizam a internet como plataforma, meio ou apoio (NOGUEIRA, 2014), ou como define Gomes (2005, p. 217), a democracia

11 Embora os movimentos tenham registrado motivações diferenciadas, carregaram a característica comum de envolver a defesa de princípios da democracia, seja contra a opressão nos países árabes, contra os cortes orçamentários em políticas sociais, além de outros efeitos da crise econômica na Espanha ou o no movimento de resistência aos impactos do sistema financeiro nos Estados Unidos. 
digital é um expediente semântico "empregado para referir-se à experiência da internet e de dispositivos que lhe são compatíveis, todos eles voltados para o incremento das potencialidades de participação civil na condução dos negócios públicos".

O autor ressalta que, no âmbito da democracia digital, a participação pública é parte do processo político, trabalhado a partir de uma comunicação de mão dupla entre Estado e sociedade, o que poderia ser avaliado a partir de cinco níveis não estanques - uma vez que cada caso pode misturar diferentes níveis e patamares -, mas que oferecem aspectos a serem observados, como descrito no quadro 1.

\section{Quadro 1 - Níveis de democracia digital}

\begin{tabular}{|c|c|}
\hline Nível & Aspectos a serem observados \\
\hline Nível 1 & $\begin{array}{l}\text { Os serviços do Estado podem ser feitos pela rede, e informações simples estão à disposição do } \\
\text { cidadão. }\end{array}$ \\
\hline Nível 2 & Um Estado onde os cidadãos são consultados e conseguem influenciar a agenda pública. \\
\hline Nível 3 & $\begin{array}{l}\text { Há um alto nível de transparência e prestação de informação entre o cidadão e o Estado. O Estado } \\
\text { presta contas, mas ainda não usa a contento as contribuições do cidadão nas decisões políticas. }\end{array}$ \\
\hline Nível 4 & $\begin{array}{l}\text { A democracia digital segue o modelo da democracia deliberativa, que combina participação e } \\
\text { representação, com um Estado mais permeável à opinião e participação popular. }\end{array}$ \\
\hline Nível 5 & Corresponde aos modelos da democracia direta. \\
\hline
\end{tabular}

Fonte: GOMES, 2005 apud NOGUEIRA, 2013, p. 31.

A OCDE sugere em seu índice "E-democracy", descrito no relatório de 2003, que é preciso que os governos se apoderem dos processos das novas tecnologias e criem mecanismos de participação para o cidadão dada a demanda das sociedades e seus atores, de forma que as iniciativas digitais possam melhorar as práticas dos governos, parlamentos e outras instâncias do Estado sem necessariamente vir a substituí-las.

O relatório "E-Government Survey 2012 - E-government for the people" (ONU, 2012) e outras edições da publicação, como a de 2014, "E-Government for the Future We Want", também ressaltam a importância da democracia digital e a viabilidade de sistemas nacionais e subnacionais de governança centrados no cidadão, socialmente inclusivos e participativos.

$\mathrm{O}$ índice E-participation, monitorado pela ONU, avalia ferramentas ofertadas pelo Estado a partir de três outros sub-índices, a saber: 1) e-informação, que analisa se existem nos sítios oficiais ferramentas de disseminação de informações de natureza pública; 2) econsulta, observando se os espaços trazem explicações sobre mecanismos de participação e discussões e; 3) e-tomada de decisão, avaliando se os entes estatais levam em 
consideração a opinião do cidadão ao tomar as decisões e dão retorno sobre os resultados das questões levantadas por ele, estando o Brasil, nas edições já publicadas, geralmente na metade do espectro dos países analisados.

Os sub-índices da ONU guardam bastante proximidade com as exigências ou requisitos democráticos trabalhados por Silva (2009) e que serão apresentados no percurso metodológico desta dissertação, referindo-se à publicidade, à responsividade e à porosidade na relação entre o Estado e o cidadão, aspectos que são desmembrados por Sampaio no modelo de apreensão deliberativa online em outros critérios que passam a incluir ainda aspectos como o desenho das mídias digitais onde ocorre o debate político, o processo discursivo dos atores e a forma como ocorre a interação, o que nos pareceu mais apropriado para a proposta de um estudo que inclui não somente a análise de ferramentas oferecidas pelo Estado no meio digital, mas a forma como se articulam os atores da sociedade civil entre si, com os instrumentos que aparecem no ciberespaço e com os entes estatais.

Sublinhamos aqui a relevância de estudos como o que propomos nesta dissertação, uma vez que enquanto existem uma série de cases e estatísticas sobre o consumo e a relação do cidadão com empresas e marcas privadas, no que se refere à interatividade com o governo, o número de materiais disponíveis cai consideravelmente. Mesmo os levantamentos desenvolvidos por organismos como o Comitê Gestor da Internet no Brasil (CGI, 2014; 2016), que estabelece diretrizes estratégicas relacionadas ao uso e desenvolvimento na internet no país, não conseguem alcançar com relativa profundidade os fatores concorrentes para a participação social pela internet, o que de algum modo pode explicar por que a iniciativa privada já vem adotando uma comunicação digital proativa e interativa com seus atores de interesse há mais tempo e de forma mais satisfatória que o setor público.

Como destaca Nogueira (2014, p. 48), “à medida que se tem todos os serviços e informações em um mesmo meio (a internet), fica mais fácil comparar funcionalidades e atividades de cada um e exigir os mesmos padrões e códigos de comunicação de ambos", ou seja, as pessoas parecem esperar que todas as instâncias funcionem dentro dos moldes de interação que elas conhecem, dentro de suas redes sociais e pelos canais que tem funcionado na interação com empresas, amigos e outros com quem tem interesses comuns. 
Dessa forma, é possível que a internet venha a tornar a participação política cada vez mais fácil no cotidiano (GIARDELLI, 2013; CASTELLS, 2013) e não que ela seja simplesmente algo que se espera ocorrer durante períodos eleitorais, podendo um dia nos depararmos com uma situação em que veremos as pessoas tão confortáveis em seu papel de cidadãos como em outros diferentes aspectos da vida (JENKINS, 2009).

Buscamos neste capítulo fazer um apanhado do arcabouço teórico e dos principais debates que permeiam este estudo, refletindo sobre os principais conceitos que serão trabalhados ao longo da dissertação e apresentando os elementos e cenários que motivam esta investigação. Nas páginas seguintes, trabalharemos com um resgate sobre o conceito de direito cultural e sobre o desenvolvimento das políticas públicas de cultura no Brasil, com destaque aos mecanismos de participação social, descrevendo no capítulo 3 nosso percurso metodológico e resultados apresentados no caso analisado das redes de participação social em políticas públicas de cultura no Distrito Federal. 


\section{DIREITO CULTURAL E POLÍTICAS PÚBLICAS DE CULTURA}

Conforme expusemos brevemente no capítulo anterior, a concepção de desenvolvimento que agrega à dimensão econômica fatores de ordem social, ambiental e cultural traz consigo um olhar abrangente e carregado de significados simbólicos que incorporam características relacionadas aos modos de pensar e viver em sociedade.

Sob esse aspecto, coube às políticas culturais nas últimas décadas institucionalizar a relação entre cultura, cidadania e direitos culturais, de forma que o Estado assumisse o papel de promotor de meios e equipamentos para universalização do acesso pleno à cidadania. Como observa Amartya Sen:

O que as pessoas conseguem positivamente realizar é influenciado por oportunidades econômicas, liberdades políticas, poderes sociais e por condições habilitadoras como boa saúde, educação básica e incentivo e aperfeiçoamento de iniciativas. As disposições institucionais que proporcionam essas oportunidades são ainda influenciadas pelo exercício das liberdades das pessoas, mediante a liberdade para participar da escolha social e a tomada de decisões públicas que impelem o progresso dessas oportunidades. (SEN, 2000, p. 19)

Nesse sentido, os debates consubstanciados em instrumentos legais que conclamam a cultura como elemento constitutivo do desenvolvimento oferecem alguns subsídios para análise do papel dos direitos culturais e de seu pleno exercício na formação do próprio conceito de cidadania.

A Declaração Universal dos Direitos Humanos, de 1948, insere em seu artigo 27 os direitos culturais como parte integrante das garantias jurídicas universais que protegem indivíduos e grupos de ações ou omissões que atentem contra a dignidade humana. Sua expressão é clara ao indicar que "toda a pessoa tem o direito de tomar parte livremente na vida cultural da comunidade, de fruir as artes e de participar no progresso científico e nos benefícios que deste resultam", acrescentando ainda que "todos têm direito à proteção dos interesses morais e materiais ligados a qualquer produção científica, literária ou artística da sua autoria".

Os direitos culturais figuram ainda em outro importante tratado internacional: o Pacto Internacional sobre os Direitos Econômicos, Sociais e Culturais, de 1966, que além de definir o compromisso dos Estados integrantes em reconhecer a todos o direito de participar da vida cultural e trabalhar pelo desenvolvimento da ciência e da cultura, nos 
artigos 13 e 15 manifesta o direito humano a uma educação que habilite o desempenho de um papel útil numa sociedade livre, promotora da compreensão, da tolerância e da amizade entre as nações e grupos raciais, étnicos e religiosos.

No âmbito interamericano, os direitos culturais estão indicados no Protocolo Adicional à Convenção Americana sobre Direitos Humanos, de 1988, que ficou conhecido como Protocolo de São Salvador. O artigo 13 assegura o direito à educação, orientado para o pleno desenvolvimento da pessoa humana e do sentido de sua dignidade, visando ao fortalecimento e ao respeito pelos direitos humanos, ao pluralismo ideológico, às liberdades fundamentais, à justiça e à paz. Já o artigo 14 estabelece o direito aos benefícios da cultura, reconhecendo aqueles que decorrem da promoção e desenvolvimento da cooperação e das relações internacionais em assuntos científicos, artísticos e culturais e, na mesma linha, comprometendo-se a propiciar maior cooperação internacional.

A Agenda 21 da Cultura, documento firmado por representantes de governos locais de diversas partes do mundo em 2004, reafirmou os princípios da Declaração Universal sobre a Diversidade Cultural, adotada pela Unesco em 2001. Ao mesmo tempo em que afirma os direitos das pessoas à livre expressão cultural, os documentos observam que ninguém pode invocar a diversidade cultural para infringir os direitos humanos nem limitar o seu exercício.

A Convenção da Unesco de 2005 sobre a Proteção e Promoção da Diversidade das Expressões Culturais constituiu um importante marco legal do direito internacional, na medida em que versa sobre os direitos e reconhece as obrigações do Estado no que se refere à formulação e implementação de políticas culturais, bem como a adoção de medidas para proteção e promoção da diversidade das expressões culturais.

A Carta Cultural Ibero-Americana, de 2006, resgata alguns desses instrumentos, valorizando os programas de desenvolvimento ao reafirmar os valores da democracia, a livre criação, a plena participação dos povos na cultura, bem como a necessidade de que isso ocorra em um ambiente de liberdade e justiça, destacando ainda o valor estratégico da cultura na própria economia e sua contribuição para o desenvolvimento econômico, social e sustentável.

Por fim, a Declaração de São Paulo sobre Cultura e Sustentabilidade, assinada em 2012 durante as atividades preparatórias para a Conferência Rio+20, enfatiza a "transversalidade e o papel da cultura na construção de uma resposta aos desafios da 
sustentabilidade e do desenvolvimento humano com equidade e inclusão social", reconhecendo também o componente ambiental da diversidade cultural dos povos sulamericanos, o que abrange conhecimentos tradicionais e modos próprios de viver como patrimônio material e imaterial.

\subsection{DIVERSIDADE E DIREITO CULTURAL}

O reconhecimento e a proteção da diversidade no âmbito do direito cultural merecem especial atenção no período deste estudo, quando políticas estruturadas sobre os eixos de valorização dessa dimensão parecem correr o risco de serem abandonadas em diversas partes do mundo, e especialmente no Brasil, "repetindo modelos já testados em gestões anteriores a 2002 e cuja farta bibliografia acadêmica aponta o caráter elitista e de balcão de negócios" (MAKIUCHI, 2016, p. 5).

Castells (1999, p. 41) observa que "em um mundo de fluxos globais de riqueza, poder e imagens, a busca de identidade, coletiva ou individual, atribuída ou construída, torna-se a fonte básica de significado social" e, nesse sentido, como aponta Amartya Sen (2000, p. 25), “as liberdades não são apenas os fins primordiais do desenvolvimento mas também os meios principais", uma vez que garantem aos sujeitos a oportunidade de cuidar de si mesmos e influenciar o mundo, questões centrais para o processo de desenvolvimento.

A questão da participação, nesse sentido, é fundamental para alguns dos problemas básicos que têm minado o alcance das teorias do desenvolvimento, como destaca Sen, pois:

\footnotetext{
as concepções individuais de justiça e correção, que influenciam os usos específicos que os indivíduos fazem de suas liberdades, dependem de associações sociais - particularmente da forma interativa de percepções do público e da compreensão cooperativa de problemas e soluções. (SEN, 2000, p. 46)
}

E o autor completa que "a análise e a avaliação das políticas públicas têm de ser sensíveis a essas diversas relações", pois as pessoas diretamente envolvidas que têm de ter a oportunidade de participar da decisão do que deve ser escolhido, do que elas desejam e do que elas estão certas ao aceitar.

É certo que as instituições democráticas não podem ser vistas como dispositivos 
mecânicos para o desenvolvimento, sendo fundamental examinar constantemente os meios disponíveis para fazê-las funcionar bem, o que é proposta deste estudo.

\subsection{A CONSTRUÇÃO DAS POLÍTICAS PÚBLICAS DE CULTURA NO BRASIL}

O movimento de institucionalização das políticas culturais ao redor do mundo materializado na criação do Ministério dos Assuntos Culturais na França, em 1959, bem como em iniciativas de encontros e conferências promovidos pela Unesco entre a década de 1970 e início dos anos 2000 - acontece concomitantemente com a implementação dos projetos de desenvolvimento na América Latina (RUBIM, 2009).

No Brasil, esse processo consubstanciado pelo planejamento de políticas governamentais revelou também um momento de desenvolvimento do capitalismo no país voltado para o fortalecimento tanto de um mercado de bens materiais como de um "mercado de bens simbólicos que diz respeito à área da cultura" (ORTIZ, 1985, p. 81), com reflexos sobre a formulação e implementação de políticas culturais, muitas vezes confundidas com políticas de financiamento artístico.

Há certa convergência entre os estudiosos que os anos 1930 marcaram o início das políticas culturais brasileiras. É nesse momento que a área cultural é organizada com a institucionalização de estruturas capazes de gerir a política pública, entre elas o Instituto Nacional de Cinema Educativo (1936), o Serviço do Patrimônio Histórico e Artístico Nacional (1937) e o Instituto Nacional do Livro (1937) (CARMO, 2016).

No período de 1964 a 1984 são criadas as "principais instituições estatais que organizam e administram a cultura nas suas diferentes expressões" (ORTIZ, 1985, p. 85), sendo tanto um período importante no qual se produzem e se difundem bens culturais (que passam a ganhar dimensão nacional) como um momento no qual há forte repressão ideológica quanto às artes e à cultura no país.

A partir de 1975, a ação governamental se intensifica por meio da elaboração do primeiro Plano Nacional de Cultura, da criação da Fundação Nacional de Artes (Funarte) e da reformulação administrativa da Empresa Brasileira de Filmes (Embrafilme). No período seguinte, de 1985 a 2002, é criado o Ministério da Cultura (1985); são inseridos os direitos culturais na Constituição de 1988, que prevê seu pleno exercício; e surgem as leis de incentivo fiscal (CARMO, 2016). 
Na Constituição Federal de 1988, os artigos 215 e 216 tratam especificamente dos direitos culturais, assumindo o compromisso de que "o Estado garantirá a todos o pleno exercício dos direitos culturais e acesso às fontes da cultura nacional, e apoiará e incentivará a valorização e a difusão das manifestações culturais" e explicitando que "constituem patrimônio cultural brasileiro os bens de natureza material e imaterial, tomados individualmente ou em conjunto, portadores de referência à identidade, à ação, à memória dos diferentes grupos formadores da sociedade brasileira".

No artigo 216-A, destaca-se o compromisso assumido pelo Estado brasileiro no que se refere à democratização dos processos decisórios e de gestão no âmbito das políticas culturais, com redação dada pela Emenda Constitucional n ${ }^{\circ} 71$, de 2012, explicitando ainda os órgãos que compõem o Sistema Nacional de Cultural (SNC):

Art. 216-A. O Sistema Nacional de Cultura, organizado em regime de colaboração, de forma descentralizada e participativa, institui um processo de gestão e promoção conjunta de políticas públicas de cultura, democráticas e permanentes, pactuadas entre os entes da Federação e a sociedade, tendo por objetivo promover o desenvolvimento humano, social e econômico com pleno exercício dos direitos culturais.

$\S 1^{\circ} \mathrm{O}$ Sistema Nacional de Cultura fundamenta-se na política nacional de cultura e nas suas diretrizes, estabelecidas no Plano Nacional de Cultura, e regese pelos seguintes princípios:

$[\ldots]$ social;

X - democratização dos processos decisórios com participação e controle

XI - descentralização articulada e pactuada da gestão, dos recursos e das ações;

[...]

$\S 2^{\circ}$ Constitui a estrutura do Sistema Nacional de Cultura, nas respectivas esferas da Federação:

I - órgãos gestores da cultura;

II - conselhos de política cultural;

III - conferências de cultura;

IV - comissões intergestores;

$\mathrm{V}$ - planos de cultura;

VI - sistemas de financiamento à cultura;

VII - sistemas de informações e indicadores culturais;

VIII - programas de formação na área da cultura; e

IX - sistemas setoriais de cultura. (BRASIL. Constituição (1988). Emenda Constitucional $\mathrm{n}^{\circ} 71$, de 29 de novembro de 2012. Acrescenta o art. 216-A à Constituição Federal para instituir o Sistema Nacional de Cultura. In: BRASIL. Constituição (1988). Constituição da República Federativa do Brasil. Brasília, DF: Presidência da República. Disponível em <http://www.planalto.gov.br/ccivil_03/constituicao/constituicaocompilado.htm>. Acesso em: 21 jan. 2017.

A partir de 2003, o Estado brasileiro amplia o conceito de cultura em seus programas e políticas e tenta estimular o debate sobre a concepção de políticas públicas na 
área, por intermédio do Conselho Nacional de Política Cultural (CNPC) e da realização de seminários e conferências nos diversos níveis federativos que culminam na institucionalização e implementação do Plano e do Sistema Nacional de Cultura, instituído pela Emenda Constitucional no 71/2012.

O reflexo dessa nova perspectiva de gestão das políticas de cultura pode ser mensurado nos municípios pelo aumento de secretarias exclusivas - de 4,2\% em 2006 para 20,4\% em 2014 - e pelo número de conselhos municipais de cultura - se em 2006, apenas 17\% dos municípios tinham conselho em 2014 esse número subiu para 38,6\% (IBGE, 2015a). Esse aumento é acompanhado pela institucionalização de leis de sistemas de cultura, conselhos, planos, fundos de financiamento e pela busca de formação mais qualificada dos gestores (CALABRE, 2009). Desse modo, o Sistema é uma tentativa de institucionalizar e criar políticas permanentes de cultura em todo o país com ampla participação da sociedade civil e com o objetivo de garantir o pleno exercício dos direitos culturais. (CARMO, 2016).

Outro instrumento incluído na Constituição Federal foi o Plano Nacional de Cultura (PNC), sobre o qual trataremos nas páginas seguintes e que se refere a um conjunto de princípios, objetivos, diretrizes, estratégias e metas que devem orientar o poder público na formulação de políticas culturais por um período de dez anos. Ele está previsto no artigo 215 da Constituição e foi criado pela Lei n ${ }^{\circ} 12.343$ de 02 de dezembro de 2010 , sendo sua criação resultado de um processo de discussões em fóruns, seminários, conferências e consultas públicas, sob a supervisão do CNPC.

\subsection{DELIBERAÇÃO E PARTICIPAÇÃO SOCIAL NAS POLÍTICAS CULTURAIS}

Instituído pela Lei $\mathrm{n}^{\mathrm{o}} 12.343 / 2010$, o PNC adotou a esfera civil como elementochave para a elaboração das 14 diretrizes, 36 estratégias e 275 ações dedicadas à definição do papel do Estado e da sociedade civil na proteção e na promoção da diversidade artística e cultural, no acesso aos bens culturais e no desenvolvimento socioeconômico sustentável, o que resultou em 53 metas para a cultura a serem atingidas até 2020 .

Uma dessas metas (Meta 48) estabelece a criação e a promoção de uma plataforma digital de governança colaborativa implementada como instrumento de participação 
social $^{12}$ com 100 mil usuários cadastrados, observada a distribuição da população nas macrorregiões do país, o que aponta algumas perspectivas e limitações para a democracia digital no Brasil a partir de um olhar sobre a adesão e as formas de engajamento à proposta.

Da aprovação do PNC até o fim de 2015, a plataforma reuniu quatro diferentes iniciativas, sendo elas uma página eletrônica de acompanhamento das metas do Plano Nacional de Cultura (pnc.culturadigital.br/); a plataforma Cultura Digital, voltada à interação e estruturação de redes de acompanhamento público dos processos de realização das políticas culturais (culturadigital.br/); a plataforma do Sistema Nacional de Informações e Indicadores Culturais (SNIIC), que funciona como um banco de dados de bens, serviços, infraestrutura, investimentos e outras informações relativas ao setor cultural (sniic.cultura.gov.br/); e a plataforma Vota Cultura (cultura.gov.br/votacultura), disponibilizada em 2015 para votação de delegados e acompanhamento das eleições para o CNPC, órgão colegiado composto por integrantes de diversos segmentos que tem por finalidade propor a formulação de políticas públicas para o desenvolvimento e o fomento das atividades culturais no território nacional.

A Tabela 1 apresenta o número de usuários cadastrados na Plataforma Digital de Governança Colaborativa por ano, onde ressalta-se que no ano de 2015 o crescimento atípico refere-se à disponibilização da plataforma Vota Cultura para as eleições do CNPC, conforme exposto na Tabela 2. A meta para 2020 pressupõe a distribuição relativa da população brasileira nas macrorregiões, considerando que, para compor os $100 \%$ dos 100 mil usuários previstos na meta para o país em 2020 sejam considerados $8,3 \%$ para a região Norte, $27,8 \%$ para a região Nordeste, $7,4 \%$ para a região Centro-Oeste, $42,1 \%$ para a região Sudeste e $14,4 \%$ para a região Sul.

12 Embora diversos autores admitam que participação e deliberação não sejam conceitos idênticos, os termos caminham juntos em inúmeros trabalhos (COHEN e FUNG, 2004; FUNG, 2004; VITALE, 2006) dado que tanto participacionistas quanto deliberacionistas defendem que eleições periódicas não são suficientes para legitimar as decisões políticas nas democracias liberais representativas. 
Tabela 1 - Adesão à Plataforma Digital de Governança Colaborativa do Ministério da Cultura

\begin{tabular}{llcccc}
\hline \multicolumn{1}{c}{ Indicador } & $\mathbf{2 0 1 3}$ & $\mathbf{2 0 1 4}$ & $\mathbf{2 0 1 5}$ & Meta para 2020 \\
\hline $\begin{array}{l}\text { Número de usuários cadastrados na plataforma na } \\
\text { região Norte }\end{array}$ & 328 & 1.143 & 23.368 & 8.318 \\
\hline $\begin{array}{l}\text { Número de usuários cadastrados na plataforma na } \\
\text { região Nordeste }\end{array}$ & 1.022 & 3.112 & 25.100 & 27.829 \\
\hline $\begin{array}{l}\text { Número de usuários cadastrados na plataforma na } \\
\text { região Centro-Oeste }\end{array}$ & 1.106 & 1.913 & 7.327 & 7.367 \\
\hline $\begin{array}{l}\text { Número de usuários cadastrados na plataforma na } \\
\text { região Sudeste }\end{array}$ & & & & \\
\hline $\begin{array}{l}\text { Número de usuários cadastrados na plataforma na } \\
\text { região Sul }\end{array}$ & 4.680 & 1.880 & 10.639 & 14.358 \\
\hline $\begin{array}{l}\text { Número de usuários cadastrados na plataforma em todo } \\
\text { o país }\end{array}$ & 9.860 & 13.822 & 82.909 & 100.000 \\
\hline
\end{tabular}

Fonte: MINC. Acompanhamento de Metas do Plano Nacional de Cultura. Disponível em: $<$ http://pnc.culturadigital.br/metas/plataforma-de-governanca-colaborativa-implementada-como-instrumentode-participacao-social-com-100-mil-usuarios-cadastrados-observada-a-distribuicao-da-populacao-nasmacrorregioes-do-pais/>. Acesso em: 30 mai. 2016.

Tabela 2 - Iniciativas que integram a Plataforma Digital de Governança Colaborativa do Ministério da Cultura

\begin{tabular}{cc}
\hline Iniciativa & Número de usuários cadastrados no ano de 2015 \\
\hline $\begin{array}{c}\text { Página de acompanhamento das metas do PNC } \\
\text { (pnc.culturadigital.br) }\end{array}$ & 580 \\
\hline Plataforma Cultura Digital (culturadigital.br) & 1.359 \\
\hline $\begin{array}{c}\text { Plataforma do Sistema Nacional de Informações e } \\
\text { Indicadores Culturais (sniic.cultura.gov.br) }\end{array}$ & 17.770 \\
\hline Plataforma Vota Cultura & 72.869 \\
\hline
\end{tabular}

Fonte: Elaborado pela autora. Informações fornecidas pela Secretaria de Políticas Culturais do Ministério da Cultura em 30 mai. 2016.

Pela tabela 1 é possível observar que, enquanto em 2013 e 2014 a adesão à plataforma seguia lentamente, em 2015, por conta da disponibilização de ferramenta para eleição do CNPC, foi registrado um significativo avanço no número de usuários cadastrados na Plataforma, atingindo 83\% da meta prevista para 2020 em âmbito nacional, com destaque à região Norte, que atingiu $281 \%$ da meta apenas em 2015 , enquanto a região Sudeste registrou o menor índice, com 39\% de adesão no ano. De acordo com o Ministério da Cultura, para fins de aferição da meta foi feito um cruzamento das informações exposta na tabela 1 para que não houvesse dupla contagem dos dados. Já na 
tabela 2, referente ao ano de 2015, não houve extração dos dados de usuários que estão cadastrados em mais de uma iniciativa.

De modo geral, observa-se que a plataforma consegue reunir informações, indicadores culturais e ferramentas para articulação de redes, oferecendo ainda espaços públicos fortes, onde a participação dos usuários tem potencial para resultados políticos concretos, como a plataforma Vota Cultura, que desempenhou importante papel na eleição do CNPC em 2015. Com base no grande número de cadastros de usuários no período, diferente de outros anos, em que a adesão seguia a passos lentos, é possível observar uma preferência do público-alvo da plataforma por dispositivos que ofereçam experiências de resultado direto no processo deliberativo, sendo importante avaliar, em ocasião oportuna, se as pessoas continuam engajadas nos espaços após o processo eleitoral, além do comportamento quanto à exigência de cadastro e consequente impossibilidade de anonimato, limitada conexão com outros aspectos da vida do usuário, diferente de sites de redes sociais, entre outras questões que podem vir a desestimular o engajamento.

No Distrito Federal, a atuação do segmento artístico $^{13}$ na regulação das políticas públicas segue historicamente a tendência nacional, embora acrescente ainda algumas peculiaridades em termos práticos. Conforme atestam os documentos da época, na década de 1980 - antes da criação da Secretaria de Cultura do Distrito Federal (Secult), até então ligada à Secretaria de Educação -, a extinta Fundação Cultural do DF - mais tarde absorvida pela Secult -, começava a autorizar a participação de um representante da comunidade no conselho gestor da entidade.

Em 1989, a criação do Conselho de Cultura do Distrito Federal passou a prever a participação comunitária em metade dos 12 cargos do colegiado, um dos responsáveis pela criação, em 1991, do Fundo de Apoio à Cultura do DF (FAC), uma proposta do Conselho de Cultura encaminhada à Câmara Legislativa do Distrito Federal (CLDF) pelos representantes do Poder Executivo à época.

Em 1999, quando o Decreto n ${ }^{\circ} 20.264$ estabeleceu a extinção da Fundação Cultural do DF e a reestruturação da Secretaria de Cultura, a Lei Complementar no 267/1999 reivindicada pelos segmentos sociais ligados à produção cultural - passou enfim a prever a origem dos recursos que iriam compor o FAC, vinculando-o sobretudo às dotações

13 Segundo dados da Secretaria de Cultura do Distrito Federal, até o final de janeiro de 2017 a região possuía cerca de 7 mil artistas, produtores e entidades culturais com pedido de registro junto à pasta no Cadastro de Entes e Agentes Culturais (CEAC). 
orçamentárias do Distrito Federal.

É também nesse ano que artistas, produtores culturais e outros integrantes do segmento começam a se organizar em torno do Fórum de Cultura do Distrito Federal, um organismo suprapartidário, sem personalidade jurídica, regimento, estrutura ou composição formais, articulado para fins de discussão, controle social e apresentação de propostas para as políticas culturais da região com a contribuição de outros atores individuais, fóruns, movimentos sociais, colegiados e demais redes.

Posteriormente, outros grupos foram se formando e atores individuais passaram a agir também em busca de uma relação direta com o Estado no desenvolvimento das políticas públicas de cultura, chamando atenção, a partir dos anos 2000, a articulação dessas redes por meio de comunidades virtuais, seja inicialmente por grupos de e-mail e, posteriormente, a partir de sites de redes sociais, entre outras mídias.

O caso do Fórum de Cultura do Distrito Federal, que aparece entre as fanpages analisadas no capítulo 3 - nos parece especialmente interessante. Alguns dos atores que tivemos a oportunidade de entrevistar neste estudo e que integram o Fórum relatam que o marco inaugural da rede estaria relacionado a uma insatisfação generalizada do movimento cultural do DF em torno de mudanças na gestão e na concepção da Rádio Cultura FM, a emissora pública da região, em meados da década de 1990. Na avaliação desses atores, houve uma queda expressiva de qualidade na programação, o que mobilizou uma manifestação em defesa da Rádio na época. $\mathrm{O}$ ato reuniu milhares de pessoas ao redor do Teatro Nacional Cláudio Santoro, em Brasília.

Verificando a força da mobilização, os artistas e produtores culturais começaram a se reunir periodicamente e, em 1999, o Fórum resolveu lançar-se para o Distrito Federal, organizando uma série de intervenções artísticas e outras atividades culturais em um dos teatros de Brasília naquele ano.

Em 2005, os integrantes do organismo resolveram criar um grupo de e-mails que, em 2015, chegou a mais de 500 membros e, juntamente com as reuniões presenciais nãoregulares, serviu à discussão de ações pelo aprimoramento de políticas de cultura na região, o que, com a expansão da plataforma Facebook foi sendo deslocado para uma fanpage - em 2015 com uma média de 600 seguidores - e um grupo fechado na mesma plataforma com pouco mais de 1200 membros. 


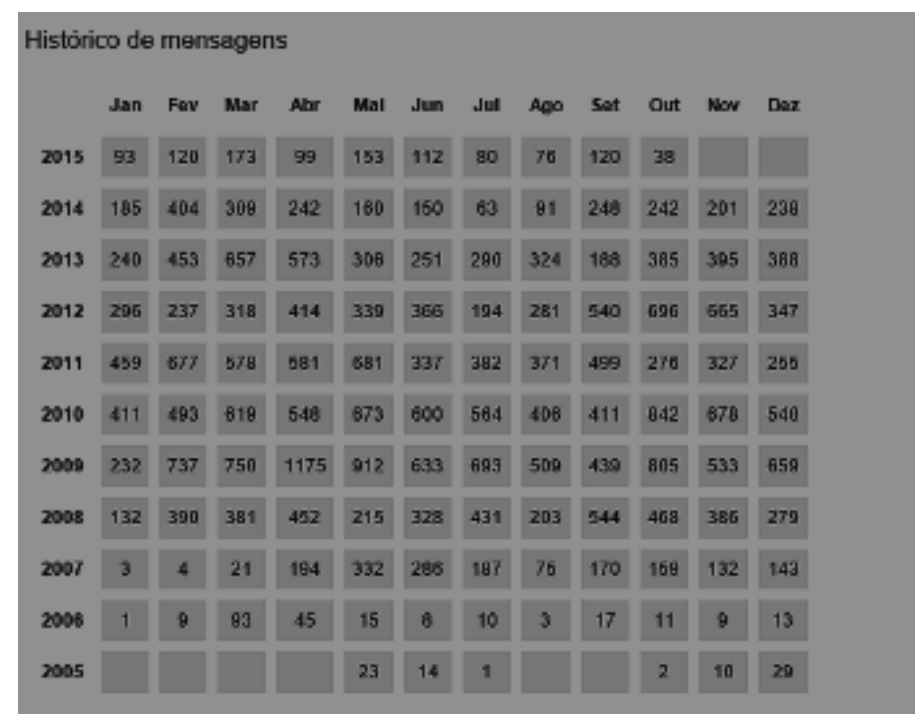

Fonte: Yahoo Grupos Brasil. Acesso em: 04 dez. 2015.

Pode-se observar pela figura 2 que, no período de 2005 a 2015, foram trocadas mais de 39.275 mensagens apenas no grupo de e-mails do Fórum. De 2005 (79 mensagens) a 2009 (8.077 mensagens), nota-se um crescimento expressivo na comunicação da rede por essa ferramenta, ao passo que de 2010 (6.785 mensagens) a outubro de 2015 (1.064 mensagens) a queda é gradual, possivelmente influenciada pela criação de outros espaços de interação digital, como aqueles vinculados à plataforma Facebook, que abordamos neste estudo.

Em nosso percurso metodológico - sobre o qual trataremos no capítulo a seguir observamos, sobretudo durante a realização de entrevistas com artistas e produtores culturais da região, um destaque em suas próprias falas sobre conquistas que atribuem à articulação de redes sociais apoiados no ambiente virtual e voltadas ao tema política cultural, tais como a Emenda à Lei Orgânica $n^{\circ} 52 / 2008$, que ampliou os recursos do Fundo de Apoio à Cultura do Distrito Federal para 0,3\% da receita corrente líquida do DF, as mobilizações para o cumprimento da legislação vigente e a proposta por trás de grandes eventos para garantia de incentivo à cultura local, como ocorreu durante o aniversário de 50 anos de Brasília, quando produtores locais se organizaram em um projeto denominado "Brasília Outros 50", exigindo a valorização dos artistas da região nas comemorações, além de outros episódios que exigiram ou vêm exigindo maior articulação social. 


\section{PARTICIPAÇÃO SOCIAL E DELIBERAÇÃO ONLINE NAS POLÍTICAS DE CULTURA DO DISTRITO FEDERAL}

Como destacamos ao longo desta dissertação, este estudo foi motivado por questionamentos quanto a perspectivas e fatores concorrentes para efetivação da participação social por meio da internet, buscando entender:

a) a concepção que atores sociais e entes estatais possuem sobre a participação social por esse meio;

b) se canais de interação para fins políticos na internet - sejam os oferecidos pelo Estado ou aqueles articulados pela sociedade civil - cumprem requisitos democráticos e atendem às características do ciberespaço;

c) qual o nível de interação entre Estado e sociedade civil por meio da internet;

d) se os debates desenvolvidos no campo digital são efetivados em ações e deliberações públicas e;

e) em que medida a organização social de atores em redes na grande rede mundial de computadores tende a fortalecer ou enfraquecer a deliberação pública.

Ao revisar a literatura sobre os temas tratados ao longo dessas páginas, avaliamos que a abordagem metodológica da Teoria Ator-Rede (LATOUR, 1994; 2011; 2012) - que sugere ao pesquisador a atenção sobre os lastros deixados pelas interações dos actantes em redes - nos oferece a perspectiva adequada aos nossos objetivos de pesquisa, sendo eles identificar canais de interação entre Estado e sociedade civil na internet com vistas à participação política; avaliar o grau de aproveitamento desses canais e; analisar as características e o comportamento das autoridades públicas e da sociedade civil quanto à participação nas decisões de interesse público com o uso de recursos compatíveis com a internet.

À luz da Teoria Ator-Rede (TAR), buscamos atender a esses objetivos propondo um estudo de caso (LAVILLE; DIONNE, 2008; CRESWELL, 2007) sobre redes formadas na plataforma digital Facebook, voltadas à discussão de políticas públicas de cultura no Distrito Federal - região que compreende a capital do Brasil e arredores -, considerando fatores como viabilidade para coleta de dados e aprofundamento da análise, bem como a pertinência do material apresentado pelo caso em questão ao objeto de estudo democracia 
digital.

Nesse sentido, optamos pela utilização de dois instrumentos de pesquisa trabalhados em interface com a perspectiva metodológica da Teoria Ator-Rede: o primeiro refere-se ao mapeamento de redes em mídias digitais, a partir do qual selecionamos o material a ser analisado e fizemos as primeiras ligações, buscando traços ou vestígios deixados pelos elos entre os actantes, como propõe a TAR, que pudessem ser analisados em profundidade no segundo momento da pesquisa. Vale ressaltar que o mapeamento de redes em mídias digitais é utilizado aqui apenas enquanto instrumento para coleta de dados, analisados dentro da perspectiva metodológica da TAR. Essa pontuação é importante, uma vez que o mapeamento de redes em mídias digitais, somado a outros elementos de avaliação e técnicas de pesquisa, vem sendo empregado, de forma mais usual, dentro da perspectiva da Análise de Redes Sociais ${ }^{14}$ que, embora possua pontos convergentes com a TAR, configura-se como abordagem metodológica distinta da empregada neste estudo.

Mapeadas as redes com as quais trabalhamos nesta investigação, passamos ao segundo momento da pesquisa, que se refere a aplicação de modelo de apreensão deliberativa online(MAIA, R. C. M; GOMES, W.; MARQUES, F. P. J. A., 2011; SAMPAIO, 2012; SAMPAIO; BARROS; MORAIS, 2012) com o apoio de entrevistas semiestruturadas, uma proposta que resgata elementos teóricos das correntes deliberacionista e participacionista da democracia, adaptando-os ao cenário de exercício cívico digital e sua lógica de estruturação em redes e comunidades virtuais.

Ao restabelecer o conceito de social (ou o que concerne o relacionamento entre indivíduos) a partir das dinâmicas associativas e dissociativas, a TAR busca uma análise baseada na identificação dos lastros resultantes das convergências e divergências entre os atores de uma rede, que podem ser inclusive objetos, desde que inseridos nas dinâmicas constituídas dentro de um determinado tecido social. Esse "ator", na expressão hifenizada "ator-rede", destaca Latour (2012, p. 75), "não é a fonte de um ato e sim o alvo móvel de um amplo conjunto de entidades que enxameiam em sua direção”.

Nesse ponto, vale destacar que, para a TAR, é importante reconhecer se os "meios de produzir o social" são encarados como intermediários ou mediadores. Para Latour

14 Sobre a discussão entre pontos convergentes e divergentes entre a Teoria Ator-Rede e a Análise de Redes Sociais, vide BASTOS, G. S.; RECUERO, R. Encontros e desencontros entre TAR e ARS: o laço fraco entre teoria e método. Contemporânea (UFBA Online), v. 12, p. 1-15, 2014. 
(2012, p. 65), um intermediário é "aquilo que transporta significado ou força sem transformá-lo: definir o que entra já define o que sai”. Os mediadores, por sua vez, "não podem ser contados como apenas um, eles podem valer por um, por nenhuma, por várias ou uma infinidade. $\mathrm{O}$ que entra neles nunca define exatamente o que sai; sua especificidade precisa ser levada em conta todas as vezes."

Cabe aqui destacar que a própria internet, bem como os meios que lhe são compatíveis e influenciam as interações dos actantes que constituem as redes de participação social, e que apresentamos neste estudo, não podem ser desprezados nesta análise como importantes mediadores, o que explica nossa escolha por instrumentos de pesquisa (FLICK, 2002; FLICK, 2004) como o mapeamento de redes em mídias digitais dentro da perspectiva de análise da TAR e a aplicação do modelo de apreensão deliberativa online, dado que o próprio meio onde são formadas as redes nos demonstrou exercer influência sobre a formação das redes e sobre a interação entre seus actantes.

Sendo um olhar para associações e dissociações permanentemente tensionadas, uma análise fundamentada na TAR busca evidenciar elementos dinâmicos, destacando os pontos de passagem significativos dos processos em constituição a partir dos lastros ou traços deixados pelos mediadores ou nós das redes, o que dá ao estudo um caráter imprevisível e carregado de incertezas.

Para Latour (2011, p. 315), na análise de redes “a única coisa que podemos fazer é observar tudo o que está atado às afirmações”, como a forma como são feitas as atribuições de causas e efeitos, que pontos estão interligados, que dimensões e força têm as ligações, quais são os mais legítimos porta-vozes e como todos esses elementos são modificados durante as controvérsias ou fontes de incertezas que abrem as "caixas-pretas" de articulação das redes.

\subsection{A ARTICULAÇÃO DE REDES DE ARTISTAS E PRODUTORES CULTURAIS NO DISTRITO FEDERAL}

Para viabilização deste estudo, realizamos inicialmente um trabalho de aproximação com o movimento cultural do Distrito Federal, virtual e presencialmente nos debates e reuniões de articulação, com o objetivo de identificar as plataformas digitais que vêm sendo utilizadas com maior frequência por esses organismos para fins políticos.

Observamos que, internamente, os grupos de e-mails e os grupos e fanpages 
vinculados à plataforma Facebook, do grupo Facebook Inc., recebiam maior atenção do segmento cultural no Distrito Federal que outros espaços e sites de mídias sociais ${ }^{15}$. Já no que se refere ao diálogo inter-redes, as fanpages também vinculadas à plataforma Facebook se mostravam mais ativas que outros ambientes virtuais. Os sites oficiais vinculados ao poder público local, em geral, não oferecem ferramentas interativas para análise deliberativa e de participação social e por isso não foram considerados neste estudo, que analisará apenas as fanpages oficiais dos entes estatais na plataforma Facebook, além das já citadas fanpages administradas por atores da sociedade civil.

Considerando essa dinâmica e avaliando a possibilidade de conseguir elementos para análise das questões elencadas, mapeamos por meio da plataforma Facebook as principais fanpages (Quadros 2, 3 e 4) que, entre as suas postagens, abordavam o tema política cultural. Em respeito à privacidade dos usuários e com base nas ferramentas de que dispomos, não consideramos perfis pessoais e grupos vinculados à plataforma Facebook, sendo analisadas apenas páginas (ou fanpages) abertas. Além das ferramentas oferecidas pelo próprio site, utilizamos mecanismos de busca $^{16}$ disponibilizados para fins de monitoramento de mídias digitais, selecionando 16 expressões-chaves: 'cultura df'; 'cultura brasília'; 'fórum cultura df; 'fórum cultura brasília'; 'fórum df'; 'fórum brasília'; 'arte df'; 'arte brasília'; 'redes cultura df'; 'redes cultura brasília'; 'pontos cultura df'; 'pontos cultura brasília'; 'cultura df'; cultura brasília'; 'política cultural df' e 'política cultural brasília'.

15 Desde o inicio de 2016, observamos um movimento de estímulo à utilização de aplicativos de comunicação para telefonia móvel, como WhatsApp, também de propriedade da Facebook Inc, para articulação das redes de artistas e produtores culturais do Distrito Federal.

16 O mecanismo de busca utilizado nesta etapa do estudo, além dos próprios instrumentos da plataforma Facebook é oferecido pela Socialbakers, uma empresa que desenvolve ferramentas gratuitas e pagas de monitoramento para análise de redes sociais como Facebook, Twitter, YouTube, LinkedIn e Google+. 
Quadro 2 - Fanpages administradas por atores da sociedade civil

\begin{tabular}{|c|c|c|c|c|}
\hline & Nome da fanpage & Moderação & Número de fãs & Link \\
\hline 1 & Fórum de Cultura do DF & Sociedade civil & 677 & $\frac{\text { https://www.facebook.com/f }}{\text { orumdeculturadf/?fref }=\text { ts }}$ \\
\hline 2 & $\begin{array}{l}\text { Fórum de Produtores Culturais na } \\
\text { UnB }\end{array}$ & Sociedade civil & 582 & $\frac{\frac{\text { https://www.facebook.com/f }}{\text { orumdeprodutoresculturais/? }}}{\underline{\text { fref }=\mathrm{ts}}}$ \\
\hline 3 & Brasília Arte Urbana & Sociedade civil & 755 & $\frac{\frac{\text { https://www.facebook.com/B }}{\text { RASILIARTEURBANA/?fr }}}{\underline{\text { ef=ts }}}$ \\
\hline 4 & Arte Brasília & Sociedade civil & 195 & $\begin{array}{l}\frac{\text { https://www.facebook.com/A }}{\text { rte-Bras\%C3\%ADlia- }} \\
\underline{689438084521299 / ? \text { fref }=\text { ts }}\end{array}$ \\
\hline 5 & Cultura Viva DF Pontos de Cultura & Sociedade civil & 214 & $\frac{\text { https://www.facebook.com/p }}{\underline{\text { ontosdeculturadf/?fref }=\mathrm{ts}}}$ \\
\hline 6 & SOS Cultura Santa Maria & Sociedade civil & 80 & $\frac{\text { https://www.facebook.com/s }}{\text { osculturasantadf/?fref=ts }}$ \\
\hline 7 & Rede de Cultura Planaltina DF & Sociedade civil & 251 & $\frac{\frac{\text { https://www.facebook.com/r }}{\text { ededeculturaplanaltinadf/?fre }}}{\underline{\mathrm{f}=\mathrm{ts}}}$ \\
\hline 8 & $\begin{array}{l}\text { Comitê de Cultura e Luta de } \\
\text { Planaltina }\end{array}$ & Sociedade civil & 206 & $\begin{array}{l}\text { https://www.facebook.com/c } \\
\text { omitedeculturaeluta/?fref=ts }\end{array}$ \\
\hline 9 & Arte Rua DF & Sociedade civil & 849 & $\begin{array}{l}\frac{\text { https://www.facebook.com/A }}{\underline{\text { rte-Rua-DF- }}} \\
\underline{207536382692182 / ? \text { fref }=\text { ts }}\end{array}$ \\
\hline 10 & Arte Urbana DF & Sociedade civil & 787 & $\frac{\underline{\text { https://www.facebook.com/a }}}{\underline{\text { rteurbanadf/?fref=ts }}}$ \\
\hline 11 & $\begin{array}{c}\text { Brasília - Patrimônio Cultural da } \\
\text { Humanidade }\end{array}$ & $\begin{array}{l}\text { Sociedade civil - } \\
\text { Agência privada }\end{array}$ & 21.912 & $\frac{\frac{\text { https://www.facebook.com/B }}{\text { rasilia.Patrimonio.Cultural/?f }}}{\underline{\text { ref }=\mathrm{ts}}}$ \\
\hline 12 & Urbanistas por Brasília & Sociedade civil & 9.267 & $\frac{\text { https://www.facebook.com/u }}{\underline{\text { rbanistasporbrasilia/?fref=ts }}}$ \\
\hline 13 & $\begin{array}{l}\text { Eu apoio o Centro Cultural da Asa } \\
\text { Norte }\end{array}$ & Sociedade civil & 1.515 & $\begin{array}{l}\frac{\text { https://www.facebook.com/c }}{\text { entroculturaldaasanorte/?fref }} \\
=\underline{\text { ts }}\end{array}$ \\
\hline 14 & Brasília - DF & Sociedade civil & 6.692 & $\begin{array}{l}\frac{\text { https://www.facebook.com/B }}{\text { ras\%C3\%ADlia-DF- }} \\
\frac{311260875581951 / ? \mathrm{fref}=p b}{\text { \&hc_location=profile_brows }} \\
\underline{\text { er }}\end{array}$ \\
\hline 15 & Manifestação Brasília & Sociedade civil & 48.792 & $\begin{array}{l}\frac{\text { https://www.facebook.com/ }}{\text { manifestacaobsb/?fref }=\text { pb\&h }} \\
\underline{\text { c_location=profile browser }}\end{array}$ \\
\hline
\end{tabular}

Fonte: Elaborado pela autora. Informações coletadas na plataforma Facebook com acesso em 30 jan. 2016. 
Quadro 3 - Fanpages humorísticas administradas por atores da sociedade civil

\begin{tabular}{|c|c|c|c|c|}
\hline & Nome da fanpage & Moderação & Número de fãs & Link \\
\hline 1 & Desgoverno do Distrito Federal & $\begin{array}{l}\text { Sociedade civil - } \\
\text { Página de humor }\end{array}$ & 9.760 & $\frac{\text { https://www.facebook.co }}{\underline{\text { m/desgovernodf/?fref=ts }}}$ \\
\hline 2 & Prefeitura de Brasília & $\begin{array}{l}\text { Sociedade civil - } \\
\text { Página de humor }\end{array}$ & 25.296 & $\frac{\frac{\text { https://www.facebook.co }}{\mathrm{m} / \text { prefeituradebrasilia/?fr }}}{\underline{\text { ef }=\mathrm{ts}}}$ \\
\hline
\end{tabular}

Fonte: Elaborado pela autora. Informações coletadas na plataforma Facebook com acesso em 30 jan. 2016.

Quadro 4 - Fanpages oficiais administradas pelo poder público

\begin{tabular}{|c|c|c|c|c|}
\hline & Nome da fanpage & Moderação & Número de fãs & Link \\
\hline 1 & Governo de Brasília & $\begin{array}{l}\text { Poder público - } \\
\text { Executivo }\end{array}$ & 167.383 & $\frac{\underline{\text { https://www.facebook.co }}}{\underline{\mathrm{m} / \mathrm{govdf} / \text { fref }=\mathrm{ts}}}$ \\
\hline 2 & $\begin{array}{c}\text { Secretaria de Cultura do Distrito } \\
\text { Federal }\end{array}$ & $\begin{array}{l}\text { Poder público - } \\
\text { Executivo }\end{array}$ & 10.971 & $\frac{\text { https://www.facebook.co }}{\underline{\mathrm{m} / \mathrm{dfsecult} / \text { ffref }=\mathrm{ts}}}$ \\
\hline 3 & $\begin{array}{l}\text { Subsecretaria de Cidadania e } \\
\text { Diversidade Cultural }\end{array}$ & $\begin{array}{l}\text { Poder público - } \\
\text { Executivo }\end{array}$ & 1.253 & $\begin{array}{l}\frac{\text { https://www.facebook.co }}{\text { m/Subsecretaria-de- }} \\
\frac{\text { Cidadania-e-Diversidade- }}{\underline{\text { Cultural- }}} \\
\frac{843338869063191 / \text { fref }}{\text { ts }}=\end{array}$ \\
\hline 4 & $\begin{array}{c}\text { Câmara Legislativa do Distrito } \\
\text { Federal }\end{array}$ & $\begin{array}{l}\text { Poder público - } \\
\text { Legislativo }\end{array}$ & 11.752 & $\frac{\underline{\text { https://www.facebook.co }}}{\underline{\text { m/cldfnoticias/?fref }=\text { ts }}}$ \\
\hline 5 & $\begin{array}{c}\text { TJDFT - Tribunal de Justiça do } \\
\text { Distrito Federal e Territórios }\end{array}$ & $\begin{array}{l}\text { Poder público - } \\
\text { Judiciário }\end{array}$ & 14.355 & $\frac{\underline{\text { https://www.facebook.co }}}{\underline{\text { m/TJDFToficial/?fref=ts }}}$ \\
\hline 6 & $\begin{array}{l}\text { Ministério Público do Distrito } \\
\text { Federal e Territórios - MPDFT }\end{array}$ & $\begin{array}{l}\text { Poder público - não } \\
\text { vinculado a Poder } \\
\text { específico }\end{array}$ & 8.971 & $\frac{\underline{\text { https://www.facebook.co }}}{\underline{\mathrm{m} / \mathrm{mpdftoficial} / \text { ?fref }=\mathrm{ts}}}$ \\
\hline 7 & Rádio Cultura FM - 100,9 & $\begin{array}{l}\text { Poder público - } \\
\text { Emissora pública } \\
\text { local vinculada ao } \\
\text { Executivo }\end{array}$ & 5.860 & $\frac{\frac{\text { https://www.facebook.co }}{\mathrm{m} / \text { CulturaFMBrasilia/?fr }}}{\underline{\text { ef=ts }}}$ \\
\hline
\end{tabular}

Fonte: Elaborado pela autora. Informações coletadas na plataforma Facebook com acesso em 30 jan. 2016. 
Como o estudo refere-se à participação social nas políticas públicas de cultura do Distrito Federal, selecionamos especificamente os canais desenvolvidos para este fim, desconsiderando fanpages e grupos de espaços culturais ou ligados a partidos políticos, campanhas eleitorais, divulgação de trabalhos, publicidade de agenda cultural, entre outras finalidades comerciais ou que não estivessem diretamente vinculadas ao tema de pesquisa.

O levantamento resultou em 15 fanpages administradas por atores da sociedade civil, além de outras duas fanpages de caráter humorístico, mas que também abordam discussões sobre políticas públicas culturais. Selecionamos ainda outras sete páginas no Facebook vinculadas aos entes dos três poderes locais.

Coletamos dados referentes às "curtidas" (neste caso, referindo-nos à opção de seguir as publicações de uma página no Facebook) das 24 fanpages selecionadas por meio do aplicativo Netvizz, ferramenta desenvolvida em 2013 e que consegue reunir os dados oferecidos pela plataforma Facebook no que se refere à relação entre fanpages, entre outras formas de interação. Essas informações foram então processadas no programa Gephi, disponibilizado ao público em 2009, e que faz a conexão entre as informações oferecidas pelo Netvizz, gerando grafos de representação das interações entre as fanpages.

A aplicação desses instrumentos voltados ao mapeamento de redes digitais nos oferece informações sobre os lastros deixados pelas conexões, que analisamos dentro da perspectiva de avaliação da TAR em suas controvérsias. A proposta nesse momento foi identificar a relação entre os nós das redes (aqui descritos como fanpages) e suas conexões, na intenção de construir interpretações a respeito da articulação das redes a partir de informações como quem está conectado a quem, se há padrões de conexão e que tipos de fatores podem estar exercendo influência sobre as conexões ou não-conexões.

A ilustração dessas conexões aparece aqui como um grafo ${ }^{17}$, que é a representação de uma matriz (conjunto de inter-relações entre os diferentes elementos que são representados pelo grafo), onde os nós (as fanpages) são apresentados como vértices e suas conexões (a opção de "curtir" ou "seguir" outras fanpages) como arestas.

Selecionamos então três elementos a serem observados no mapeamento: o grau do nós, que representa o número de conexões de uma determinada fanpage, sendo possível

\footnotetext{
${ }^{17}$ A Teoria dos Grafos tem sido muito utilizada no estudo de redes e tem suas raízes no trabalho do matemático Leonhard Euler que, em 1736, conseguiu resolver o famoso enigma das pontes de Königsberg, provando a impossibilidade de atravessar todas as sete pontes dessa cidade - então território da Prússia - apenas uma vez, saindo e retornando ao mesmo ponto.
} 
registrar o grau de entrada (as curtidas recebidas) e o grau de saída (a curtidas feitas); a modularidade, identificando as comunidades formadas a partir das curtidas de outras páginas pelas fanpages e, a partir da modularidade, observamos a formação de buracos estruturais no esforço de entender se há redes isoladas e por quem são formadas (RECUERO; BASTOS; ZAGO, 2015), analisando posteriormente e com o auxílio de outros instrumentos, como a apreensão deliberativa online e as entrevistas com os atores sociais e entes do Estado, as controvérsias envolvidas na forma como se articulam as redes.

A partir das 24 fanpages selecionadas, foram gerados 759 nós na rede, cada um representando uma fanpage na plataforma Facebook (Os 759 nós do grafo gerado a partir do cruzamento das informações no programa Gephi, bem como os graus de entrada e saída de cada uma das fanpages, podem ser consultados nos apêndices desta dissertação). Pudemos identificar que as páginas vinculadas aos órgãos oficiais do poder público possuem em média um maior grau de entrada que as fanpages administradas por atores da sociedade civil, o que mostra maior tendência do Estado em ser procurado que buscar conexões com a sociedade civil, ou seja, um esforço estatal no sentido de centralizar as discussões por meio de canais oficiais em detrimento de um empenho para acompanhar outras páginas ou monitorar o que a sociedade civil vem discutindo fora dos ambientes formais controlados pelo poder público.

Outro ponto que chamou atenção nessa etapa do estudo foi a formação de comunidades a partir das "curtidas" entre fanpages. Dentro dos 759 nós, identificamos 16 comunidades a partir do conteúdo trabalhado por cada uma das fanpages, estando oito dessas comunidades isoladas, ou seja, identificamos que não havia comunicação com as outras redes formadas pelas fanpages selecionadas no estudo. Uma delas se refere justamente ao órgão central do poder legislativo local, que não se comunicava institucionalmente enquanto Câmara Legislativa com outras redes pelo critério de acompanhamento de fanpages, ação feita somente no âmbito pessoal a partir das fanpages dos atores políticos representados pela figura dos deputados, sobretudo em períodos eleitorais.

Dentro das outras oito fanpages que formam vínculos, também observamos indícios de que as redes tendem a se comunicar a partir de afinidades e se afastar a partir das diferenças, um movimento já alertado por Mutz (2006) e que abordamos no capítulo 1 desta dissertação. Um exemplo pode ser observado na Figura 3, na qual as redes de artistas 
de rua (rede lilás na parte inferior) se distanciam das redes de tribunais de justiça e magistrados (rede laranja na parte superior).

Figura 3 - Comunidades formadas pelas redes de cultura do Distrito Federal na plataforma Facebook

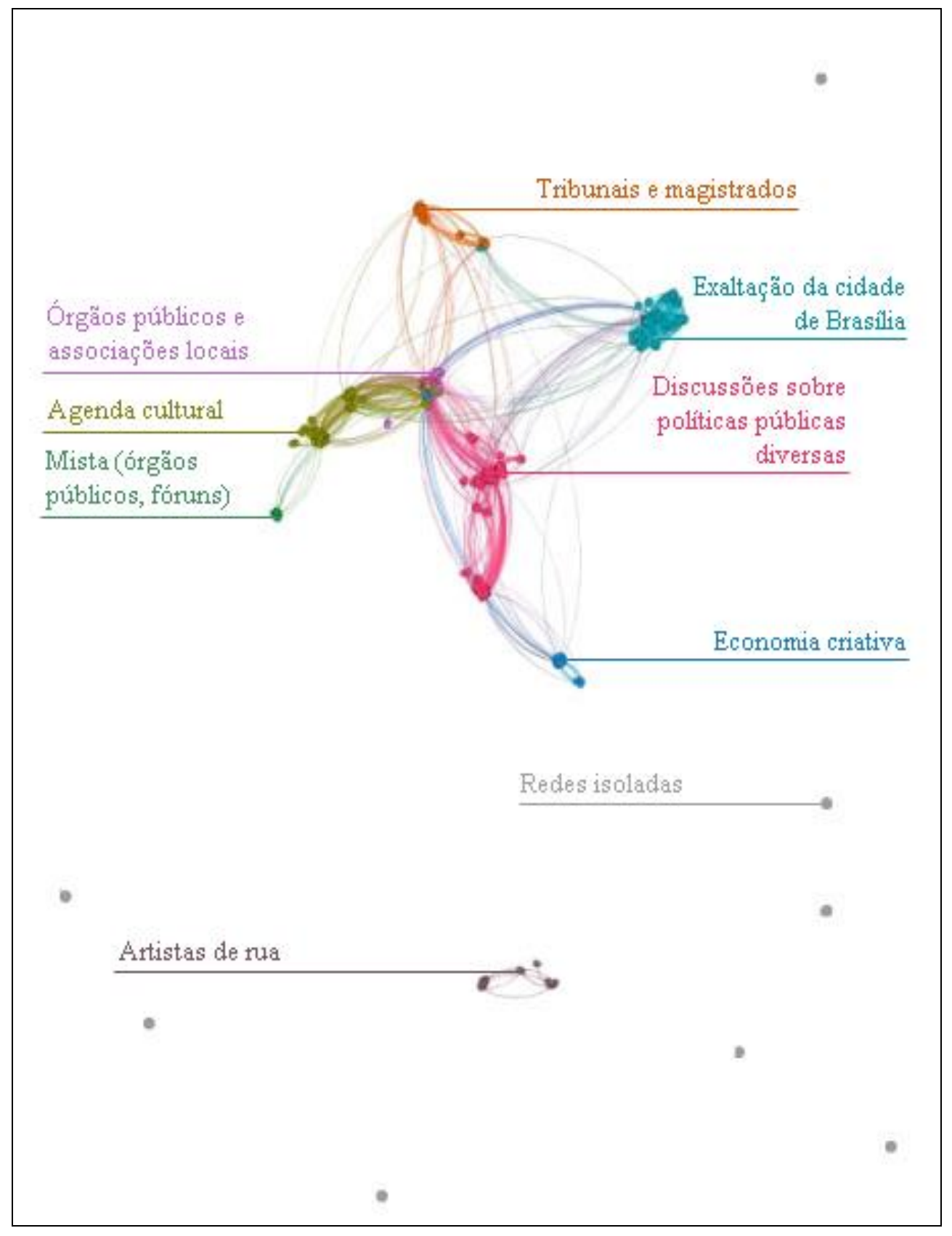

Fonte: Elaborado pela autora.

A análise preliminar dessas comunidades formadas a partir do mapeamento das fanpages apontou um esforço de diversos grupos de arte de rua (Figura 9) em dialogar 
sobre políticas culturais com outros grupos de artistas e menos com entes do Estado. No mesmo sentido, o Tribunal de Justiça do Distrito Federal (TJDFT) e magistrados locais tendiam a se comunicar mais com tribunais de outras unidades da federação (Figura 5) que com segmentos da sociedade civil sob sua jurisdição, indicando dois movimentos merecedores de atenção: o primeiro, já citado, referia-se ao esforço de centralização das discussões pelo poder público em plataformas controladas por agentes formais do Estado (todos os órgãos centrais de cada um dos três poderes possuía no período analisado uma página oficial na plataforma Facebook) quando, em sentido oposto, a dinâmica de atuação da esfera civil na internet tendia a descentralizar os núcleos de emissão de mensagens no ambiente digital, um movimento que já é observado pela iniciativa privada no Brasil, onde é possível estabelecer um diálogo horizontal entre consumidores e empresas até mesmo em perfis de usuários comuns em suas redes pessoais sem que se faça necessário ao cliente buscar a página oficial de determinada corporação para ter sua mensagem recebida, e ao considerar que as empresas estão interessadas em monitorar o que estão falando sobre ela fora dos canais oficiais.

Isso nos chama atenção para um descompasso entre as práticas estatais no ciberespaço e princípios da cibercultura. Como destacamos no capítulo 1 , o usuário de internet tende a associar as práticas cotidianas em todos os canais de comunicação. Nesse sentido, se a relação com empresas ocorre de modo a satisfazê-lo em suas necessidades de modo imediato e sem que ele precise se posicionar sobre determinada corporação indo até os canais oficiais ofertados por ela, a mesma relação é esperada dos entes estatais no ciberespaço. Se isso não ocorre, é de se esperar que a situação frustre sua vontade de interagir com o poder público e tenha impacto sobre a concepção que tem sobre essa ação.

$\mathrm{O}$ segundo movimento que citamos referia-se à dificuldade de interação entre as redes quando não há clara afinidade, o que poderia indicar como sendo um desafio para a efetivação da democracia digital a polarização nos espaços de discussão política, sendo este um aspecto que analisamos com mais profundidade por meio dos resultados obtidos na aplicação do modelo de apreensão deliberativa sobre as redes formadas pelas fanpages selecionadas, com o apoio de entrevistas com atores selecionados. 
Figura 4 - Exemplo de página identificada dentro da comunidade formada por fanpages de órgãos públicos e associações locais

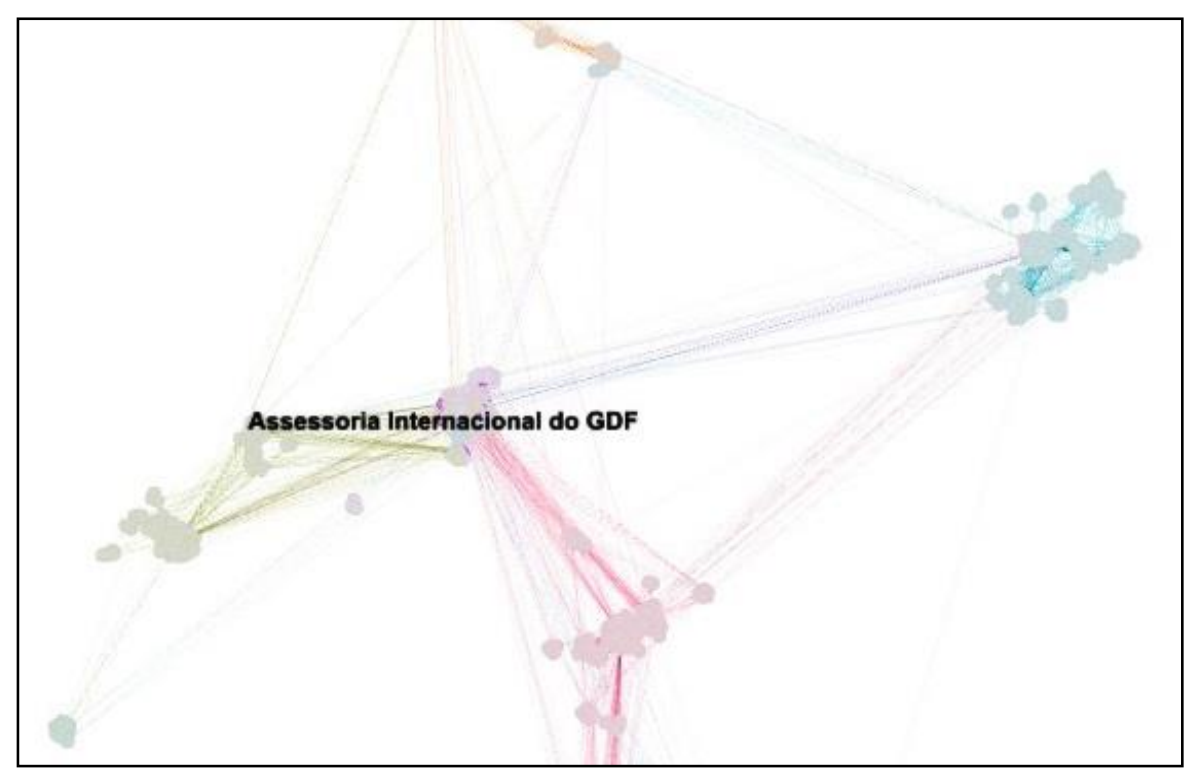

Fonte: Elaborado pela autora.

Figura 5 - Exemplo de páginas identificadas dentro da comunidade formada por fanpages de tribunais e magistrados

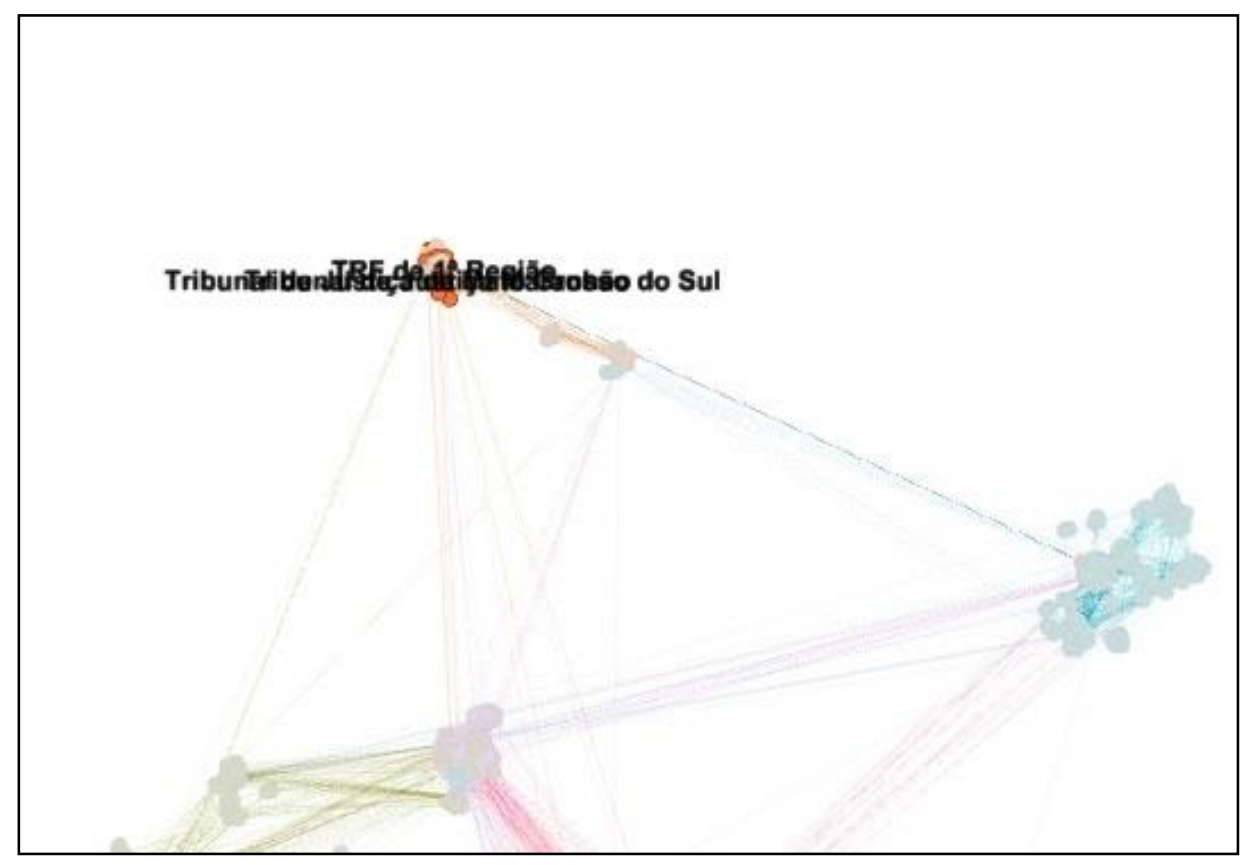

Fonte: Elaborado pela autora. 
Figura 6 - Exemplo de página identificada dentro da comunidade formada por fanpages de exaltação da cidade de Brasília

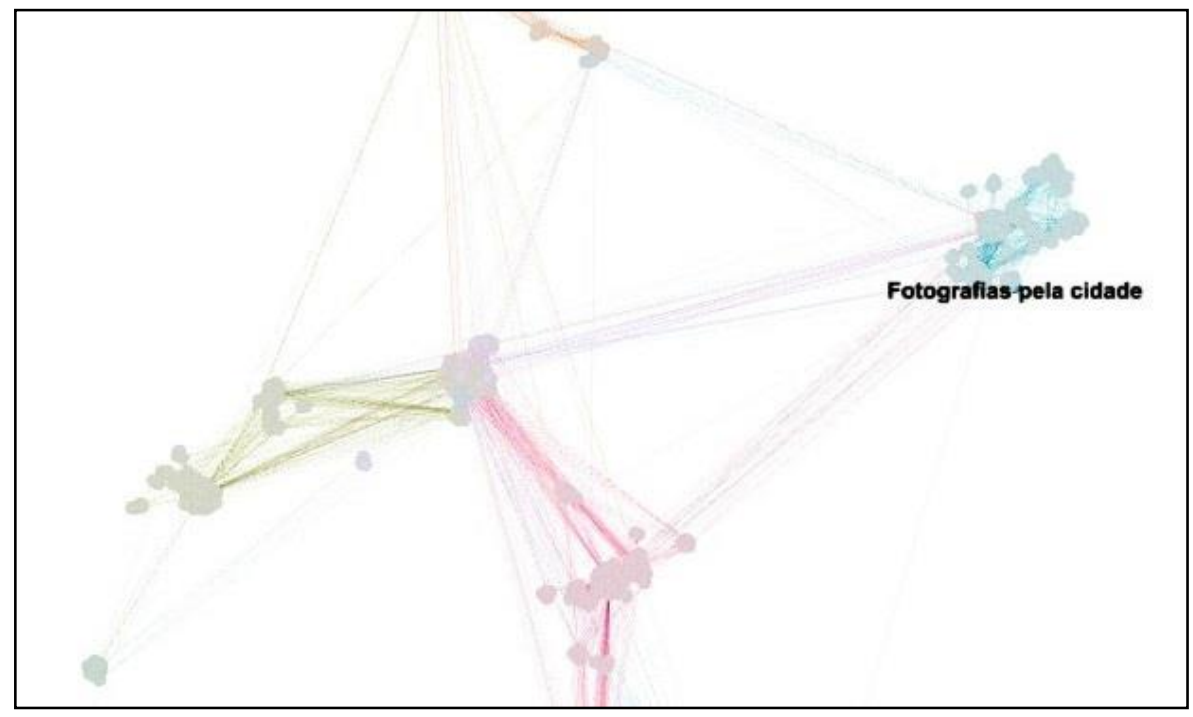

Fonte: Elaborado pela autora.

Figura 7 - Exemplo de página identificada dentro da comunidade formada por fanpages de discussões sobre políticas públicas diversas

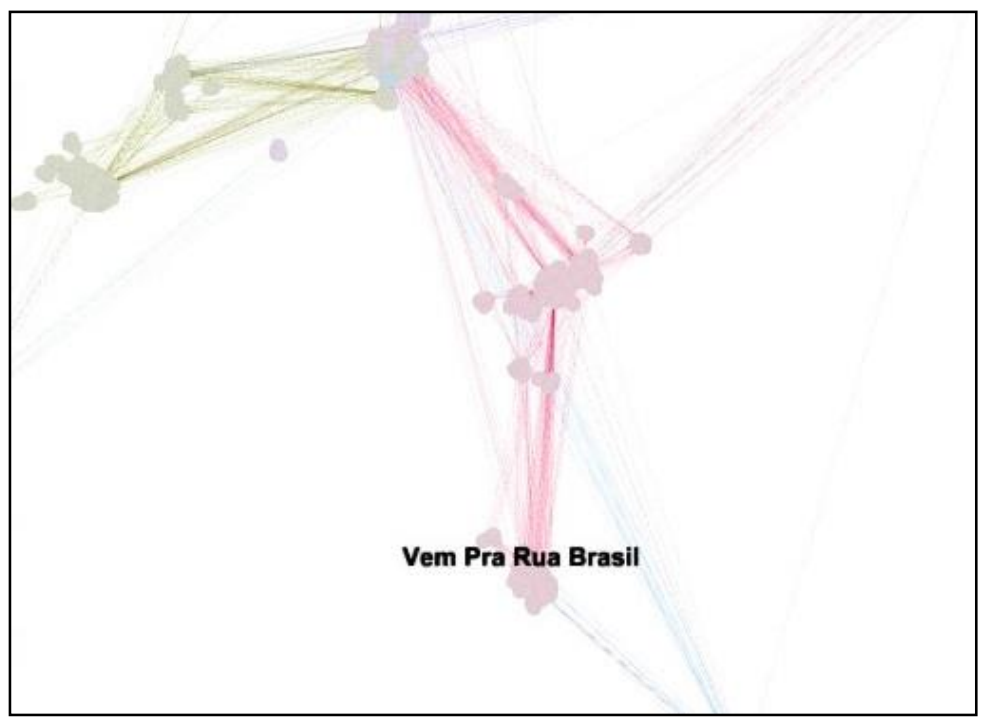

Fonte: Elaborado pela autora. 
Figura 8 - Exemplo de página identificada dentro da comunidade formada por fanpages de economia criativa

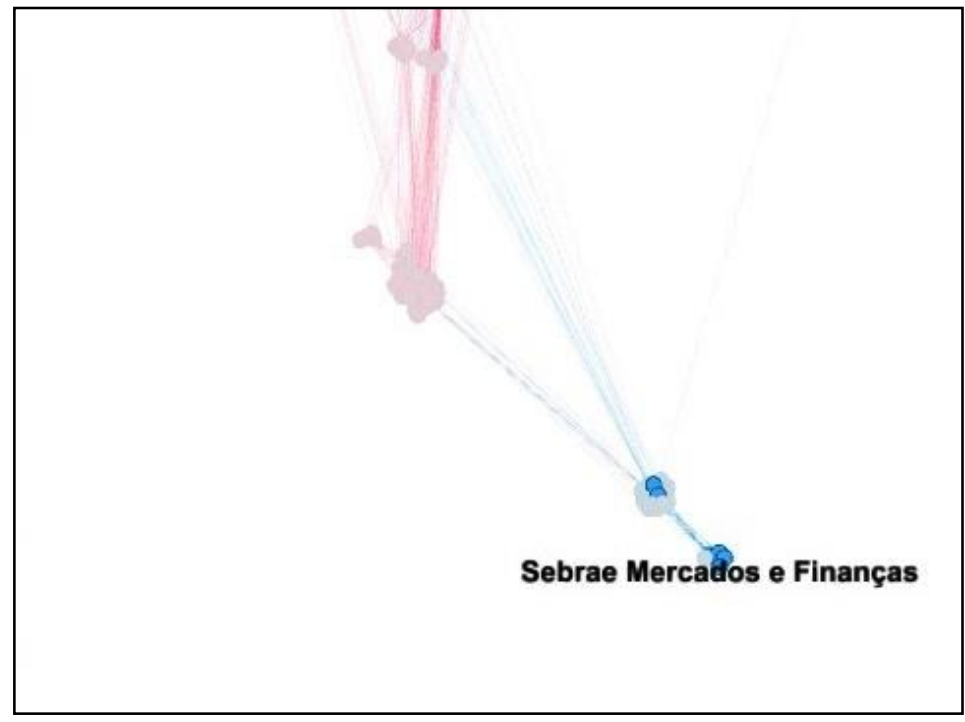

Fonte: Elaborado pela autora.

Figura 9 - Exemplo de página identificada dentro da comunidade formada por fanpages de artistas de rua

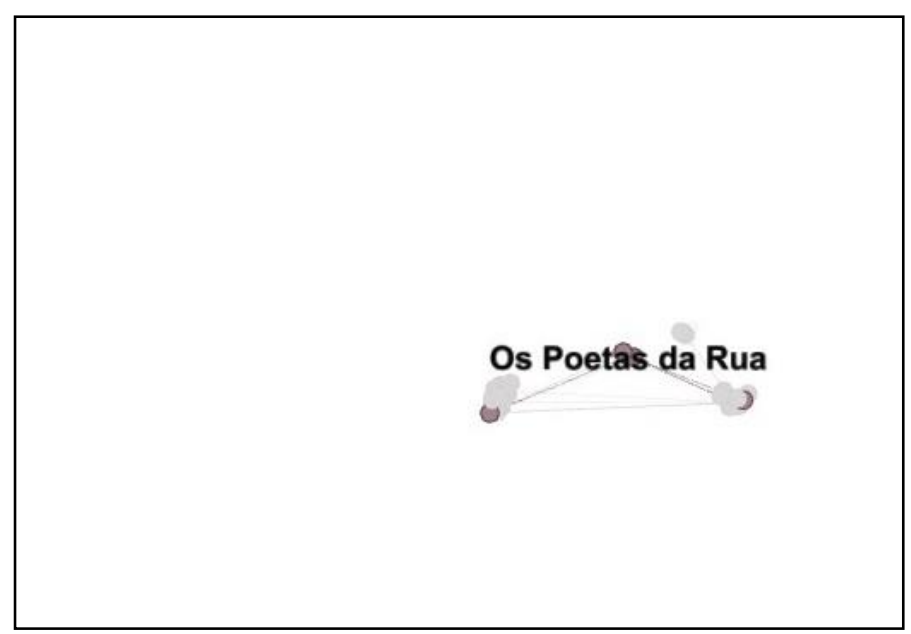

Fonte: Elaborado pela autora. 
Figura 10 - Exemplo de página identificada dentro da comunidade formada por fanpages mistas

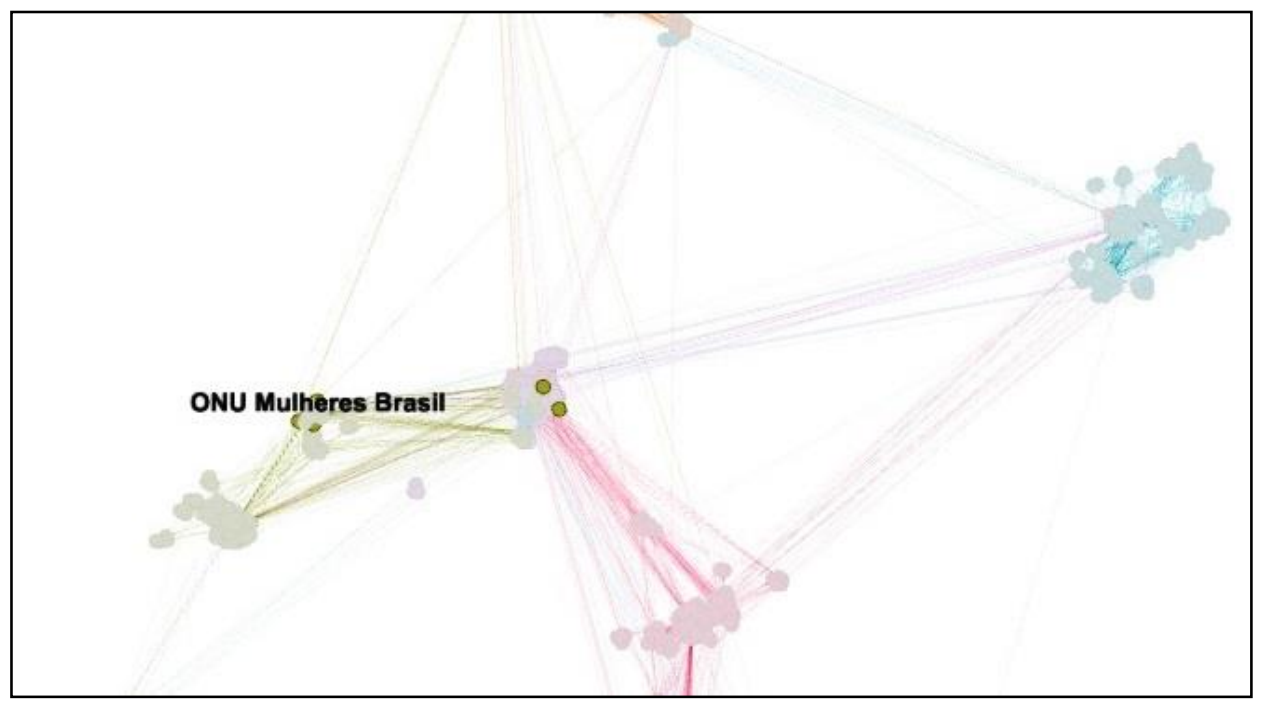

Fonte: Elaborado pela autora.

Figura 11 - Exemplo de página identificada dentro da comunidade formada por fanpages de agenda cultural

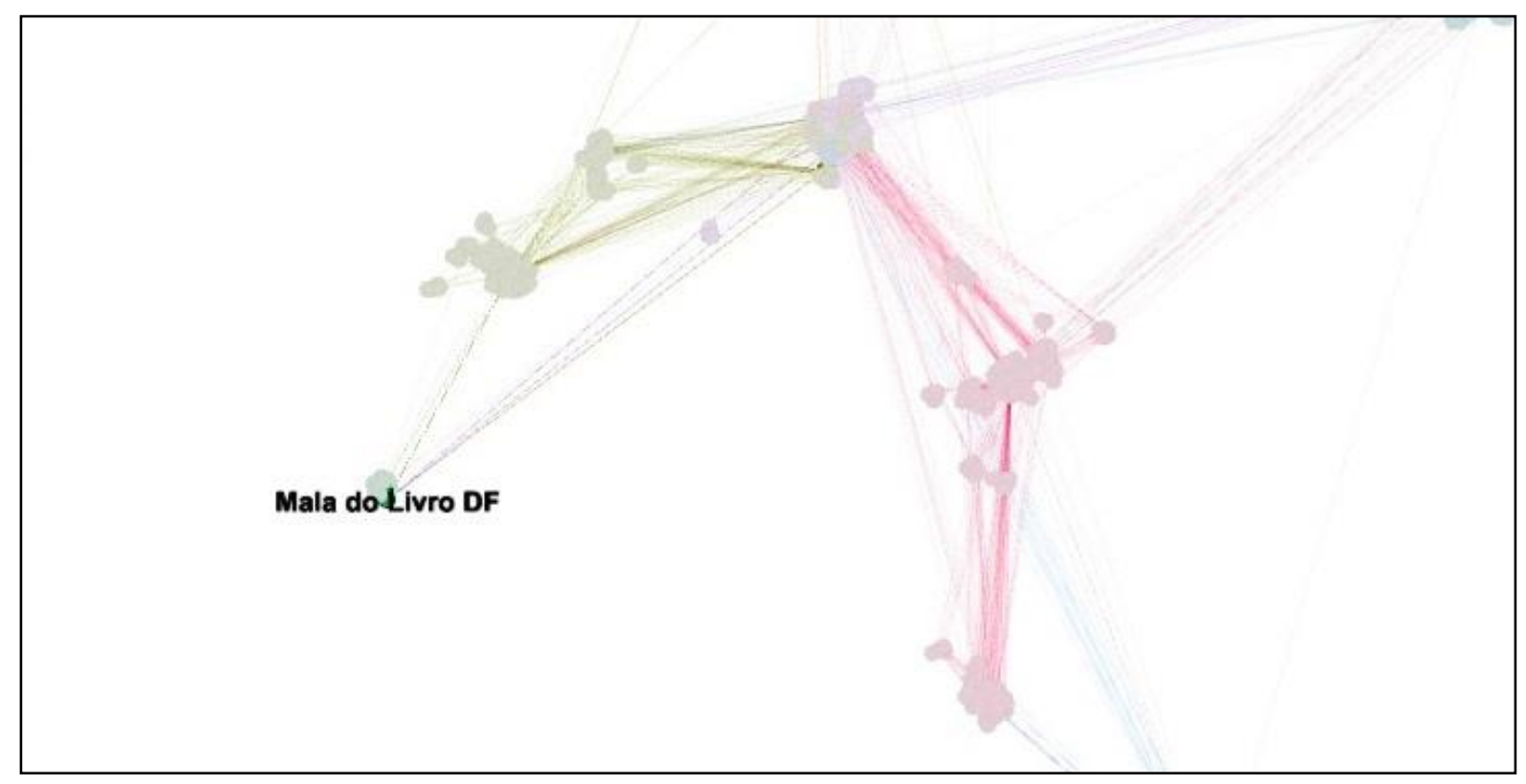

Fonte: Elaborado pela autora. 


\subsection{PARTICIPAÇÃO SOCIAL EM REDE E APREENSÃO DELIBERATIVA ONLINE}

A partir das informações que coletamos sobre as redes formadas pelos atores locais com o auxílio da internet, buscamos identificar elementos de análise dos desafios e perspectivas da democracia digital por meio de entrevistas e observação sistemática da dinâmica das redes, com o intuito de apreender o quão deliberativos os espaços criados têm sido e podem ser, e em que medida favorecem ou dificultam a participação social.

Para tanto, observamos em 24 fanpages a discussão de dois temas referentes às políticas de cultura no Distrito Federal no ano de 2015: Fundo de Apoio à Cultura e construção do Plano Distrital de Cultura ${ }^{18}$, analisando as dinâmicas de debate nas redes formadas pelas páginas na plataforma Facebook e em que medida essas discussões em redes digitais foram e/ou estão sendo consideradas na deliberação entre seus participantes e nas tomadas de decisão do poder público.

Foram realizadas 18 entrevistas, distribuídas de forma a contemplar diferentes grupos, sendo eles administradores de fanpages moderadas por atores da sociedade civil, participante/seguidor de fanpage administrada também por atores da sociedade civil, administrador de fanpage moderada por ente estatal (fanpage oficial) e autoridade ou gestor público.

As entrevistas não foram feitas com pessoas que integram grupos vulneráveis e todos os participantes foram informados sobre o contexto da pesquisa, assinando Termo de Consentimento Livre e Esclarecido - TCLE (Apêndice A) e autorizando a divulgação dos conteúdos trabalhados no contexto da pesquisa. Quanto ao monitoramento das redes formadas por fanpages, utilizamos somente o conteúdo publicizado em páginas abertas, preservando a identidade dos usuários.

Aqui, objetivamos compreender as formas de organização das redes de discussão de políticas públicas de cultura no Distrito Federal no ambiente online para investigar o comportamento dos actantes (atores sociais e entes estatais) quanto a demandas sociais e controle dos assuntos públicos - relações institucionais formais e não formais - bem como

18 O Plano Distrital de Cultura do DF vem sendo discutido desde 2015 em reuniões presenciais de atores sociais e poder público e também por uma plataforma ligada ao governo federal chamada "Participa.br". Nessa plataforma, o poder público lança algumas regras para a participação, podendo a pessoa cadastrada na plataforma sugerir questões a serem incluídas em projetos de lei e outras proposições. Vale destacar que a pessoa precisa procurar a plataforma para que possa participar e ela só fica sabendo da possibilidade de participação se provocada pelo ente estatal. 
a concepção que têm quanto à participação social pela internet (os roteiros das entrevistas semiestruturadas podem ser consultados nos apêndices desta dissertação).

Em seguida, aplicamos sobre as redes abertas formadas pelas páginas no Facebook, modelo de apreensão deliberativa online (MAIA, R. C. M; GOMES, W.; MARQUES, F. P. J. A., 2011; SAMPAIO, 2012; SAMPAIO; BARROS; MORAIS, 2012) que une conceitos e indicadores analíticos de diversos autores a partir dos elementos que apresentaremos nas páginas seguintes.

\subsubsection{Teoria Ator-Rede e apreensão deliberativa online}

Uma das contribuições mais interessantes da Teoria Ator-Rede que fomentou a nossa escolha por essa abordagem metodológica é a possibilidade de atribuir agência para entidades não-humanas, como instituições ou máquinas, no estudo de redes. Essa abertura nos pareceu particularmente interessante no contexto de emergência de dispositivos tecnológicos que interagem entre si ou com humanos, bem como dentro da própria lógica de articulação de redes no âmbito da cibercultura, sobre a qual tratamos no capítulo 1.

Ao trabalhar a tese fundamental de que o social não é uma substância, mas algo que se constrói no próprio desenvolvimento das ciências e das técnicas (LEMOS, 2013), a TAR nos provoca sobre o problema de como investigar algo que, por sua essência dinâmica, é carregado de controvérsias.

A sugestão da TAR, que adotamos neste estudo, é justamente trabalhar em cima das controvérsias e analisar os lastros deixados pelas interações, sendo o primeiro olhar voltado à identificação dos actantes das redes analisadas, o que nos desperta uma atenção especial neste estudo de caso quanto à relevância de observar, além do comportamento dos atores sociais e do poder público nas redes de participação social, a própria agência das redes sociais virtuais nas interações, bem como os lastros deixados pelas conexões que ocorrem em seu meio.

Se, por um lado, o ambiente digital aprimora o acesso a informações dada a riqueza de rastros subjetivos, comportamentais, linguísticos, financeiros, bem como interações, associações e conflitos de diversas escalas (BRUNO, 2012), por outro a quantidade de dados torna a análise mais complexa, sobretudo se consideramos que o próprio ciberespaço e as redes sociais formadas a partir dele são também actantes das redes, ou seja, também 
podem agir ou permitir a ação de outros.

Ao oferecer uma abordagem que possibilita a análise de redes absolutamente heterogêneas, a TAR traz em seu fundo teórico uma concepção de rede que não tem permanência nem localização no espaço e no tempo (LATOUR, 2012; LEMOS, 2013), constituindo-se das associações e dissociações. Nesse sentido, vale destacar que as observações que aparecem neste estudo representam apenas o contexto de articulação das redes em um determinado momento, o que é totalmente passível de ser alterado ao longo do tempo, um princípio básico com o qual trabalhamos em nosso problema de pesquisa que trata de potencialidades e limitações da participação social por redes digitais.

Ao colocarmos nosso problema de pesquisa assim, pontuamos que estamos considerando a possibilidade de alteração do cenário de participação social nas políticas públicas a partir das ferramentas e dos dispositivos oferecidos pelo ciberespaço e pelo advento das novas tecnologias de informação e comunicação, agora e cada vez mais, promovendo a articulação de redes em constante mutação.

Por isso, optamos justamente por observar o que está acontecendo nessas redes, na tentativa de desdobrar as controvérsias e rastrear as associações e dissociações que provocam as mudanças em sua articulação.

Para entender o que ocorre no instante da interação, não poderíamos senão observar como ela se dá e que tipo de influência a forma como ela se dá exerce sobre a possibilidade de que venha a se alterar. $\mathrm{O}$ modelo de apreensão deliberativa online, nesse sentido, nos parece o instrumento adequado aos nossos objetivos e aos dados dos quais dispomos, uma vez que, além de estabelecer critérios para análise dos lastros das interações, em um olhar sobre espaços de debate online, o modelo de Sampaio (2012) trabalha justamente na perspectiva de potencial da deliberação e da participação social, trazendo da categoria normativa proposta por Habermas e outros autores da democracia deliberativa aspectos para avaliação no campo empírico do quão distante os espaços de discussão estariam do tipo ideal.

\subsubsection{Apreensão deliberativa e o olhar sobre a estrutura da comunicação online}

Propondo a identificação de problemas e a colaboração em sua resolução, a democracia deliberativa se estabelece como um processo contínuo e aberto à revisão de 
posicionamento de seus participantes. O crescimento do uso da internet e a maior utilização de plataformas virtuais que trabalham a partir da interação entre os usuários têm dado sinais do que muitos deliberacionistas entendem como potencial para mitigar alguns dos principais problemas da participação nas democracias, como "a falta de tempo, o limite de espaço e a dificuldade de se considerar um número representativo de opiniões, sendo que a internet poderia até criar novas formas de mobilização" (SAMPAIO, 2012, p. 122).

Embora as pesquisas sobre deliberação online venham crescendo, sobretudo em países da Europa e Estados Unidos (JANSSEN E KIES, 2005; DAVIS, 2005; DAHLBERG, 2001; JENSEN，2003; PAPACHARISSI，2004; WILHELM，2000; WRIGHT \& STREET, 2007), estudos empíricos e modelos analíticos apenas começam a ser desenvolvidos no Brasil e alguns países da América Latina.

Alguns desses estudos vêm extraindo de reflexões de diversos autores, buscando referências para aplicação nas realidades locais. Um deles é o modelo proposto por Sampaio $(2010 ; 2012 ;$ 2012a) e adotado neste estudo que reúne sobretudo os estudos de deliberação online e processo discursivo de Dahlberg (2001) a proposições complementares de Janssen e Kies (2005) e Jensen (2003) sobre contexto sociocultural, posicionamento dos atores envolvidos e estrutura das ferramentas digitais de comunicação.

Antes da análise da interação entre os participantes, o modelo de Sampaio sugere a observação da estrutura onde ocorre o debate online no sentido de que a interação entre os atores envolvidos possa ocorrer com garantias de liberdade e igualdade, como propõem as correntes democráticas contemporâneas.

No âmbito da estrutura comunicativa, Janssen e Kies (2005) propõem que sejam analisados aspectos como acesso, liberdade de postar mensagens, impacto político, entre outros critérios ligados ao espaço onde ocorre a deliberação.

Segundo os autores, um dos aspectos a serem analisados é a identificação, sendo as mensagens classificadas como anônimas ou identificadas.

Outro aspecto seria a abertura e a liberdade de discursos, onde deve-se analisar se há alguma forma de restrição ao acesso, como cadastro ou limite de postagens.

O critério da agenda de discussão sugere a avaliação do ator político que hospeda a discussão, se pode ser feita pelos participantes, se é centralizada ou organizada por temas. Outra avaliação do ator político refere-se ao fato de haver ou não moderação, o que poderia influenciar a deliberação. 
Por fim, dentro da estrutura comunicativa propõe-se a análise do espaço deliberativo como forte ou fraco, sendo forte quando a participação puder ter resultados políticos concretos.

\subsubsection{Elementos de análise em cultura política e ideologia}

A estrutura que envolve cultura política e ideologia proposta por Janssen e Kies (2005) busca avaliar diversos aspectos que podem influenciar a deliberação, como as diferenças culturais entre regiões, o tipo de ator político a hospedar o debate e a ideologia das pessoas que são atraídas por esse ator. Outro aspecto a ser avaliado é o tópico do debate, o que pode influenciar no interesse de determinados grupos à participação. O objetivo do olhar sobre a cultura política e ideologia é entender os fatores externos que podem moldar a deliberação.

Esses aspectos ficarão mais claros na aplicação do modelo sobre as fanpages de discussão de políticas culturais no Distrito Federal, que apresentamos nas páginas seguintes.

\subsubsection{Pontos de atenção nos critérios de design e conteúdo}

Dentro dos formatos dos espaços de debate no meio digital, Sampaio (2012, p. 125) propõe a análise qualitativa de funcionalidade e conteúdo, ressaltando que "um sítio mal organizado, ou que dificulte achar as ferramentas de participação, pode inibir a ação dos cidadãos; uma ferramenta que não permita responder diretamente a outro usuário pode dificultar a deliberação, entre outras possibilidades". Em relação ao conteúdo, clareza, concisão, possibilidade de aprofundamento, entre outros aspectos, influenciariam no nível de informação dos usuários.

\subsubsection{Análise do processo discursivo na apreensão deliberativa online}

$\mathrm{Na}$ análise do processo discursivo, o primeiro critério proposto por Dahlberg (2002) e destacado no modelo de apreensão deliberativa organizado por Sampaio é chamado de tematização e críticas racionais de pretensões de validade e procura entender se as 
posições estão sendo apresentadas e se são debatidas criticamente. Se as pessoas leem e respondem as mensagens das outras, são avaliadas dentro da reciprocidade, e caso não apresentem respostas são classificadas como monológicas. Outro ponto a ser analisado é a justificação, que indica se as pessoas estão apresentando razões para apoiar seus argumentos. Sob esse aspecto, a justificação é externa quando a pessoa utiliza fatos, notícias ou dados para apoiar seus argumentos, ou interna quando é baseada em padrões e valores pessoais. Também é possível que não haja justificativa, o que se refere somente a uma posição.

O segundo critério de análise do processo discursivo é a reflexividade, que indica se as pessoas estão dispostas a avaliar a posição dos outros e até revisar a sua posição inicial, ocorrendo casos que vão da persuasão à radicalização.

O terceiro critério da análise discursiva da deliberatividade é o Ideal Role Taking, que envolve o respeito e a atenção às colocações de outros participantes do debate. Nesse sentido, o respeito implícito ocorre quando não há posições negativas nem positivas; o respeito explícito, quando há pelo menos uma posição positiva explícita sobre grupos, sendo a terceira possibilidade as mensagens sem respeito. Na ausência de respeito, seria possível ainda classificar as mensagens como rude, quando há ofensas, ironias, ataques pessoais etc. ou incivil, quando existem discursos de preconceito, racismo, ódio ou ataques contra princípios democráticos. Dentro desse terceiro critério, propõe-se também a análise da continuidade das mensagens, o que permite examinar se há regularidade nos fluxos de mensagens, por exemplo.

Outro critério que segue a proposição habermasiana da ação comunicativa é a sinceridade, que se refere, entre outros aspectos, a evitar ações estratégicas para o alcance de vantagens. Dada a dificuldade de definir parâmetros para análise desse critério, ele foi desconsiderado nesta pesquisa.

O quinto critério de Dahlberg é a inclusão e igualdade discursiva, a partir do qual deve-se analisar se o debate é aberto para todos e se os participantes têm as mesmas oportunidades de se manifestar, considerando o acesso à internet, diferenças regionais etc.

O último critério é a autonomia do Estado e do poder econômico, onde a deliberatividade é analisada a partir de sua vinculação com a razão e necessidade pública, bem como do grau de influência de fatores como o poder administrativo.

Todos esses fatores competem para a articulação das redes analisadas e a força de 
suas ligações, integrando as controvérsias das ações dos atores sociais, dos entes estatais e das próprias redes sociais virtuais, bem como das ferramentas oferecidas por elas. Os resultados dessa análise serão apresentados a seguir.

\subsection{LIMITES E PERSPECTIVAS DA DEMOCRACIA DIGITAL NAS POLÍTICAS DE CULTURA DO DISTRITO FEDERAL}

Ao propiciarem condições para a ocorrência de fenômenos como maior interatividade, liberdade de discurso e divulgação instantânea de conteúdos, as mídias digitais têm sido encaradas com maiores expectativas que os meios tradicionais de comunicação quanto às possibilidades de incremento das práticas democráticas, em especial no que se refere à participação política, seja enquanto exercício da reivindicação de direitos (DAGNINO, 2004a) ou da capacidade de influenciar no resultado das decisões de interesse coletivo (PATEMAN, 1992).

Entre os estudiosos mais céticos tanto da teoria democrática como da própria cibercultura, permanecem indagações sobre tendências de fragmentação dos debates, reabertura de espaço para grupos avessos à pluralidade e ao respeito às diferenças, além da convicção de diversos autores sobre a indisposição do sistema representativo em recolher e considerar contribuições da sociedade. Nesse sentido, como destaca Marques:

\footnotetext{
Uma vez que se parte do pressuposto de que a internet torna tecnicamente possível a existência de dispositivos de participação mais adequados para aproximar cidadãos e representantes, é preciso avaliar de que forma estes artifícios vêm sendo empiricamente adotados para este fim. (MARQUES in MAIA; GOMES; MARQUES, 2011, p. 96-97)
}

Boa parte dos pesquisadores em democracia digital tem optado por trabalhar empiricamente com ferramentas oferecidas por entes estatais na internet, como Silva (2009), que analisou os principais portais dos três poderes federativos no Brasil, propondo alguns requisitos democráticos e dimensões analíticas para a interface digital do Estado com a sociedade civil. Para o autor, a democracia deve ser pensada dentro de uma visão sistêmica, como um conjunto de peças e mecanismos que devem funcionar de modo sinérgico e integrado, sendo fundamental para qualquer análise da engrenagem democrática no ambiente digital trabalhar com pelo menos três exigências ou requisitos democráticos, a saber: (1) publicidade; (2) responsividade e; (3) porosidade, sendo que 
"o primeiro diz respeito ao princípio de tornar o Estado mais transparente ao cidadão; o segundo, de torná-lo mais dialógico e o terceiro de torná-lo mais aberto à opinião pública" (SILVA In MAIA; GOMES; MARQUES, 2011, p. 125).

O estudo apresentado aqui está amparado na análise desses três requisitos, também trabalhados, com adaptações, por organismos internacionais como a OCDE (2003) e a ONU (2014). Destacamos, no entanto, que nossa proposta está voltada para olhar não somente as ferramentas e os recursos oferecidos em iniciativas digitais coordenadas por entes estatais, mas também e sobretudo para a forma como se articulam os actantes da sociedade civil apoiados no ambiente digital, no sentido de participar das decisões de interesse coletivo.

Dentro dessa perspectiva, coube a esta investigação buscar ainda uma abordagem metodológica que pudesse dar conta de identificar e sistematizar diferentes redes de participação social, de forma a analisá-las a partir da interação entre seus actantes, avaliando o grau de aproveitamento das ferramentas e dos espaços disponíveis quanto à real utilização da internet e instrumentos compatíveis para fins de fortalecimento do exercício democrático.

$\mathrm{Na}$ Teoria Ator-Rede (LATOUR, 2012) e sua abordagem sobre lastros de interação e controvérsias, encontramos a perspectiva que consideramos adequada para analisar o processo de participação social em rede, ao unir as mais recentes técnicas de mapeamento de redes em mídias sociais, em um primeiro momento, desmembrando os requisitos de análise da democracia digital (SILVA, 2009; SILVA In MAIA; GOMES; MARQUES, 2011) em critérios de avaliação apresentados no modelo de apreensão deliberativa proposto por Sampaio (MAIA; GOMES; MARQUES, 2011; SAMPAIO, 2012; SAMPAIO; BARROS; MORAIS, 2012).

Tal modelo foi aplicado sobre as 24 fanpages selecionadas no início deste estudo de caso, sendo que sugerimos adaptações, como propõe o próprio Sampaio, para adequação às redes formadas por artistas e produtores culturais do Distrito Federal na plataforma Facebook.

Para viabilizar a análise, dada a diversidade e quantidade de publicações, fizemos um recorte sobre o ano de 2015 e sobre dois temas dentro da gama de debates sobre políticas culturais na região: o primeiro, identificamos como sendo um dos assuntos de maior interesse dos actantes dessas redes que aparece em parte significativa das 
publicações: o Fundo de Apoio à Cultura do Distrito Federal (FAC); e o segundo, com um olhar mais amplo sobre a articulação entre sociedade civil e Estado para construção e proposição de políticas culturais: o Plano Distrital de Cultura (PDC) em fase de elaboração no DF no período de realização deste estudo e que define diretrizes e metas para as políticas de cultura em um período de dez anos.

Inicialmente, cabe destacar que em parte significativa das fanpages selecionadas observamos a discussão de pautas diretamente ligadas a assuntos práticos e do dia a dia das comunidades sem que houvesse menção ao FAC ou ao PDC. Como exemplo, podemos citar mobilizações por construção ou recuperação de espaços culturais, proposta de mudanças em leis que limitam o ruído em espaços públicos ou que restringem a atuação de segmentos artísticos voltados à arte urbana, como grafiteiros e artistas de rua.

No que se refere aos temas selecionados, verificamos que, na maior parte das fanpages em que é citado, o tema FAC recebeu maior atenção que o tema PDC no período analisado, enquanto na página da Secretaria de Cultura do Distrito Federal, gerenciada pelo poder público, houve um esforço maior para mobilizar os atores sociais para discussão do PDC, como é possível observar na tabela 3.

Tabela 3 - Total de publicações das fanpages citando os temas selecionados

(continua)

\begin{tabular}{ccc}
\hline Fanpage & $\begin{array}{c}\text { Publicações da } \\
\text { página sobre o FAC }\end{array}$ & $\begin{array}{c}\text { Publicações da página } \\
\text { sobre o PDC }\end{array}$ \\
\hline Fórum de Cultura do DF & 24 & 6 \\
\hline Fórum de Produtores Culturais na UnB & 4 & 4 \\
\hline Brasília Arte Urbana & 0 & 0 \\
\hline Arte Brasília & 0 & 0 \\
\hline Cultura Viva DF Pontos de Cultura & 0 & 0 \\
\hline SOS Cultura Santa Maria - DF & 0 & 0 \\
\hline Rede de Cultura Planaltina DF & 0 & 0 \\
\hline Comitê de Cultura e Luta de Planaltina - DF & 0 & 0 \\
\hline Arte Rua DF & 0 & 0 \\
\hline Arte Urbana DF & 0 & 0 \\
\hline Brasília - Patrimônio Cultural da Humanidade & 0 & 0 \\
\hline Urbanistas por Brasília & 0 & 0 \\
\hline Eu apoio o Centro Cultural da Asa Norte & 1 & 0 \\
\hline Brasília - DF & 0 & 0 \\
\hline Manifestação Brasília & 0 & 0 \\
\hline Desgoverno do Distrito Federal & 0 & 4 \\
\hline Prefeitura de Brasília & 0 & 50 \\
\hline Governo de Brasília & 10 & 13 \\
\hline Secretaria de Cultura do Distrito Federal & 14 & 0 \\
\hline Subsecretaria de Cidadania e Diversidade Cultural & 21 & 0 \\
\hline
\end{tabular}


Tabela 3 - Total de publicações das fanpages citando os temas selecionados

(conclusão)

\begin{tabular}{ccc}
\hline Câmara Legislativa do Distrito Federal & 0 & 0 \\
\hline $\begin{array}{c}\text { TJDFT - Tribunal de Justiça do Distrito Federal e dos } \\
\text { Territórios }\end{array}$ & 0 & 0 \\
\hline Ministério Público do Distrito Federal e Territórios & 0 & 0 \\
\hline Rádio Cultura FM - 100,9 & 1 & 0 \\
\hline Total & 75 & 77 \\
\hline
\end{tabular}

Fonte: Elaborado pela autora.

No que se refere à interação, o número de comentários seguiu a mesma tendência de priorização do tema FAC (mostrando que, na internet, mesmo que o poder público defina uma pauta, ela só avança com o engajamento social), cujo número superou a quantidade de comentários sobre o PDC até mesmo na fanpage da Secretaria de Cultura do Distrito Federal que dava mais espaço para o segundo tema em suas publicações no espaço central da página, como mostra a tabela 4.

Tabela 4 - Total de comentários sobre os temas selecionados nas fanpages

\begin{tabular}{|c|c|c|}
\hline Fanpage & $\begin{array}{l}\text { Comentários } \\
\text { sobre o FAC }\end{array}$ & $\begin{array}{l}\text { Comentários } \\
\text { sobre o PDC }\end{array}$ \\
\hline Fórum de Cultura do DF & 6 & 2 \\
\hline Fórum de Produtores Culturais na UnB & 0 & 0 \\
\hline Brasília Arte Urbana & 0 & 0 \\
\hline Arte Brasília & 0 & 0 \\
\hline Cultura Viva DF Pontos de Cultura & 0 & 0 \\
\hline SOS Cultura Santa Maria - DF & 0 & 0 \\
\hline Rede de Cultura Planaltina DF & 0 & 0 \\
\hline Comitê de Cultura e Luta de Planaltina - DF & 0 & 0 \\
\hline Arte Rua DF & 0 & 0 \\
\hline Arte Urbana DF & 0 & 0 \\
\hline Brasília - Patrimônio Cultural da Humanidade & 0 & 0 \\
\hline Urbanistas por Brasília & 0 & 0 \\
\hline Eu apoio o Centro Cultural da Asa Norte & 0 & 0 \\
\hline Brasília - DF & 0 & 0 \\
\hline Manifestação Brasília & 0 & 0 \\
\hline Desgoverno do Distrito Federal & 0 & 0 \\
\hline Prefeitura de Brasília & 0 & 0 \\
\hline Governo de Brasília & 453 & 161 \\
\hline Secretaria de Cultura do Distrito Federal & 72 & 37 \\
\hline Subsecretaria de Cidadania e Diversidade Cultural & 17 & 1 \\
\hline Câmara Legislativa do Distrito Federal & 0 & 0 \\
\hline TJDFT - Tribunal de Justiça do Distrito Federal e dos Territórios & 0 & 0 \\
\hline Ministério Público do Distrito Federal e Territórios & 0 & 0 \\
\hline Rádio Cultura FM - 100,9 & 0 & 0 \\
\hline Total & 548 & 201 \\
\hline
\end{tabular}

Fonte: Elaborado pela autora. 
É interessante observar também a diferença entre os graus de saída e entrada de páginas administradas por actantes da sociedade civil e das fanpages vinculadas ao poder público (Tabela 5). Em geral, nota-se proporcionalmente um grau de entrada maior nas páginas vinculadas ao poder público e uma procura maior da sociedade civil por seguir entes estatais que do poder público por acompanhar as discussões fora dos espaços formais de comunicação. As páginas seguidas por órgãos públicos em geral são outros órgãos e veículos de imprensa e, nos casos das fanpages da Secretaria de Cultura do Distrito Federal e do Ministério Público do Distrito Federal e Territórios - MPDFT, observou-se um maior grau de entrada que de saída, o que entre as fanpages administradas pela sociedade civil (em maior número neste estudo) só ocorreu com a Brasília - Patrimônio Cultural da Humanidade, que é administrada por profissionais de um escritório midiático, ou seja, por especialistas em comunicação.

Analisando o conteúdo das publicações, é possível apreender ainda que as páginas administradas por entes da sociedade civil costumam compartilhar o que é disponibilizado em páginas oficiais do poder público, enquanto as fanpages de órgãos públicos só trabalham com conteúdos produzidos por suas assessorias, não havendo compartilhamento de conteúdos produzidos por atores sociais sem vínculo funcional com o Estado, mais um descompasso com os princípios da cibercultura e sua construção coletiva, multifacetada, ágil e dinâmica.

Tabela 5 - Graus de entrada e saída das fanpages selecionados

(continua)

\begin{tabular}{ccc}
\hline Fanpage & $\begin{array}{c}\text { Grau de saída } \\
\text { Quantas fanpages } \\
\text { acompanha) }\end{array}$ & $\begin{array}{c}\text { Grau de entrada } \\
\text { (É acompanhada por } \\
\text { quantas fanpages }\end{array}$ \\
\hline Fórum de Cultura do DF & 3 & 1 \\
\hline Brasília Arte Urbana & 1 & 1 \\
\hline Arte Brasília & 14 & 4 \\
\hline Fórum de Produtores Culturais na UnB & 0 & 0 \\
\hline Sultura Viva DF Pontos de Cultura & 1 & 0 \\
\hline Rede de Cultura Planaltina DF & 0 & 0 \\
\hline Comitê de Cultura e Luta de Planaltina - DF & 0 & 0 \\
\hline Arte Rua DF & 0 & 0 \\
\hline Arte Urbana DF & 15 & 3 \\
\hline Brasília - Patrimônio Cultural da Humanidade & 1 & 0 \\
\hline Urbanistas por Brasília & 3 & 39 \\
\hline Eu apoio o Centro Cultural da Asa Norte & 147 & 34 \\
\hline
\end{tabular}


Tabela 5 - Graus de entrada e saída das fanpages selecionados

(conclusão)

\begin{tabular}{ccc}
\hline Brasília - DF & 58 & 6 \\
\hline Manifestação Brasília & 7 & 5 \\
\hline Desgoverno do Distrito Federal & 221 & 11 \\
\hline Prefeitura de Brasília & 17 & 7 \\
\hline Governo de Brasília & 119 & 70 \\
\hline Secretaria de Cultura do Distrito Federal & 19 & 41 \\
\hline Subsecretaria de Cidadania e Diversidade Cultural & 156 & 12 \\
\hline Câmara Legislativa do Distrito Federal & 0 & 0 \\
\hline $\begin{array}{c}\text { Ministério Público do Distrito Federal e Territórios - } \\
\text { MPDFT }\end{array}$ & 38 & 7 \\
\hline Rádio Cultura FM - 100,9 & 19 & 22 \\
\hline
\end{tabular}

Fonte: Elaborado pela autora. Informações coletadas na plataforma Facebook com acesso em 30 jan. 2016.

\subsubsection{Análise da estrutura comunicativa das fanpages}

No que se refere ao aspecto identificação, a plataforma Facebook não exige, de maneira geral, que os usuários revelem sua identidade fornecendo dados que garantam a veracidade das informações prestadas. Feito o cadastro inicial com um e-mail válido e preenchimento de alguns campos, qualquer pessoa está apta a acompanhar páginas que sejam de seu interesse. Nas fanpages analisadas, a maior parte dos usuários possuía uma imagem e conta real, embora tenham sido registrados casos - tanto em páginas administradas por actantes da sociedade civil como por entes do poder público - de perfis falsos ou fakes, cujo usuário prefere não ser identificado ou interage de forma anônima, o que "pode tanto facilitar a discussão por minimizar as diferenças socioeconômicas entre os participantes quanto diminuir a responsabilidade em relação a ela", embora existam "indicações de que conversas online com indivíduos identificados tendem a fluir melhor" (SAMPAIO, 2012, p. 124).

Quanto à análise de abertura e liberdade, como propõem Janssen e Kies (2005), pudemos observar que, na maior parte das fanpages, o discurso é livre do ponto de vista dos administradores de conteúdo, sendo controlado apenas pelo próprio Facebook por meio de seus algoritmos e possíveis denúncias de outros usuários, o que pode resultar em ocultamento de determinadas publicações, exclusão de comentários ou até o bloqueio de perfis de usuários na plataforma. Também observamos que as páginas selecionadas e analisadas neste estudo praticamente em sua totalidade não possuíam política de uso com 
regras claras para a troca de mensagens, excetuando-se as páginas Governo de Brasília e Câmara Legislativa do Distrito Federal que descrevem no campo de informações sobre a fanpage o que é permitido e o que não é tolerado na interação.

A gente tem uma política de não bloquear as pessoas. A gente oculta quando tem palavrão ou quando a pessoa fica repetindo a mesma coisa. Tem algumas regras. Ou o Facebook faz automaticamente ou a gente faz. (Adriana Caitano, subchefe de Interação Social do Governo de Brasília e uma das administradoras da fanpage Governo de Brasília, em entrevista realizada no dia 09/11/2016.)

É interessante destacar que, por meio das entrevistas, pudemos observar uma preocupação maior desses órgãos em estabelecer a política de uso como forma de preservar a imagem institucional que para garantir condições propícias ao debate.

\begin{abstract}
A gente tem um "Sobre" aqui que funciona como um código de conduta baseado na página do Senado [Federal]. A gente coloca "Monitorado durante horário comercial, de segunda a sexta", e também tem as regrinhas que o pessoal [outros servidores da Assessoria de Comunicação da CLDF] colocou aqui. Algo também da Mesa Diretora: "os comentários publicados aqui não representam a posição institucional da Câmara". (Bruno Sodré, chefe da Seção de Divulgação da CLDF e um dos administradores da fanpage Câmara Legislativa do Distrito Federal, em entrevista realizada no dia 27/10/2016.)
\end{abstract}

Nesse sentido, observamos ainda que não houve registro de restrição de acesso a certas pessoas ou limitação do número de postagens visando impedir que as conversas fossem dominadas por poucos indivíduos, o que possui reflexos sobre a igualdade discursiva (DAVIS, 2005; WILHELM, 2000 apud SAMPAIO, 2012).

Quanto à agenda de discussão, observamos que, ao contrário do ocorre nos grupos hospedados na mesma plataforma (outra forma de interação proposta pelo Facebook na qual qualquer usuário aceito dentro da comunidade pode compartilhar publicações na timeline), nas fanpages os administradores centralizam a proposição de temas de discussão na timeline (espaço de maior destaque da página), cabendo aos demais participantes ou "seguidores" da fanpage apenas reagir demonstrando o sentimento que tiveram ao receber aquela informação ou comentando, ocasião é possível fugir do tema ${ }^{19}$.

Em todas as fanpages há moderação, o que significa que somente os administradores de conteúdo das páginas publicam ou compartilham informações

19 Algumas fanpages possuem ainda um campo isolado no canto direito da tela chamado "Publicações de visitantes" onde é possível a qualquer "seguidor" da página publicar temas diversos. No entanto, esse campo pode ser desabilitado e praticamente não é visualizado por outros usuários devido a sua posição e escolhas gráficas. 
diretamente na timeline e somente eles ou os programadores da plataforma Facebook têm o controle sobre comentários e outras formas de interação, podendo inclusive ocultá-los ou excluí-los nos casos em que julgarem conveniente.

A contenda de tal critério de análise reside na resistência ao controle e à censura na internet. Sampaio (2012) destaca que muitos participantes defendem que as discussões devem ser totalmente abertas e que os temas indesejáveis serão naturalmente combatidos pelos próprios usuários da rede. No entanto, boa parte dos pesquisadores (DAVIS, 2005; JENSEN, 2003; PAPACHARISSI, 2004; WRIGHT e STREET, 2007; JANSSEN e KIES, 2005 apud SAMPAIO, 2012, p. 124) argumenta que a moderação tende a contribuir para o debate, uma vez que organiza as discussões e inibe situações de conflito.

Dentro da análise sobre a estrutura comunicativa, cabe também observar que a maior parte das fanpages analisadas configura-se como espaços públicos fracos, dado que nenhuma decisão ou articulação política concreta costuma ser feita nas páginas, que apenas mobilizam para a deliberação ou ação direta presencial. Nesse sentido, o poder comunicativo raramente efetiva-se em poder de deliberação.

\begin{abstract}
O mais importante mesmo é o presencial, que eu sempre fiz questão. Nada se decide pelo virtual. Você não sabe quem são, de fato, os interlocutores, não sabe quem são as pessoas que estão ali. Então o virtual é sempre usado como uma referência de mobilização, uma referência de velocidade de mobilização porque todo mundo tem um telefone, sabe ali o endereço [eletrônico], o cara está ali na lista, você sabe que ele está lendo, então ele se informa. As situações mais graves de enfrentamento com o Estado a gente sempre fez presencialmente, mas o virtual sempre foi uma ferramenta de mobilização, de troca de ideias para a gente reunir, mandar os textos, fazer a construção de redação virtual. Mas só aprova a redação quem foi presencialmente. (Rênio Quintas, maestro e um dos administradores da fanpage Fórum de Cultura do DF, em entrevista realizada no dia 04/11/2016.)
\end{abstract}

No entanto há páginas tanto administradas por actantes da sociedade civil como por entes do poder público que chegam a apresentar traços de espaços públicos fortes, como a Urbanistas por Brasília, dado que são feitas discussões em profundidade com justificação e articulação na própria página para ações diretas e indiretas com potencial para resultados concretos; a Eu apoio o Centro Cultural da Asa Norte, na qual há registros de articulação na própria fanpage para ações efetivas; e a Governo de Brasília, dado que as demandas apresentadas tendem a receber encaminhamento ou pelo menos retorno do poder público.

O mais comum é que a participação seja por meio de canais da internet devido às dificuldades rotineiras para interações presenciais, que exigem uma 
disponibilidade de tempo muito maior. O movimento Urbanistas por Brasília já atuou de forma mais assertiva em vários momentos importantes da cidade, nos quais destaco um projeto de expansão do Setor Hoteleiro Norte que seria feito irregularmente na quadra 901 norte, ameaça de aprovação precipitada do Plano de Preservação do Conjunto Urbanístico de Brasília (PPCUB), risco de desativação e demolição do Cine Drive-in de Brasília (o último do Brasil) e ameaça de construção do Memorial João Goulart em frente ao Memorial JK. Em todas essas situações foi necessário fazermos pressão por meio de petições online, contatos com a imprensa, mobilização da população e intervenção em páginas de órgãos do governo. (Cristiano Nascimento, arquiteto e urbanista e administrador da fanpage Urbanistas por Brasília, em entrevistada realizada no dia 13/11/2016.)

Nesse critério de classificação dos espaços são evocados os três requisitos democráticos destacados por Silva (2009), seja a publicidade e a responsividade, mas principalmente a porosidade, o que nos pareceu um dos maiores desafios da democracia digital nas políticas de cultura do Distrito Federal, sendo que tal requisito é o que mais incorpora as demandas de participação, pois é o que efetivamente abre as instâncias de decisão e resolução de conflitos aos cidadãos, exigência clássica na história da democracia.

\begin{abstract}
No início, a Ouvidoria questionou "se a pessoa quer reclamar, ela vai na Ouvidoria." Só que a pessoa pode não querer registrar uma demanda na Ouvidoria. Às vezes ela quer uma coisa muito concreta, por exemplo "Como eu faço para inscrever o meu filho na creche?" Essa informação ela quer na hora, não quer mandar para a Ouvidoria. Às vezes a pessoa fala "Tem um buraco enorme na minha rua”. E geralmente mandamos direto para a Novacap [Companhia Urbanizadora da Nova Capital do Brasil, vinculada ao Governo de Brasília]. Às vezes, se tem alguma denúncia mais séria, pedimos que a pessoa registre na Ouvidoria, mas não é tudo. Tem coisa que é do dia e as pessoas se acostumaram com a nossa página. Hoje elas sabem que se elas têm dúvida, se têm alguma coisa para falar, elas vêm até a nossa página. (Adriana Caitano, subchefe de Interação Social do Governo de Brasília e uma das administradoras da fanpage Governo de Brasília, em entrevista realizada no dia 09/11/2016.)
\end{abstract}

\title{
3.3.2 Observações sobre cultura política e ideologia
}

No modelo de apreensão deliberativa proposto por Sampaio são citados ainda aspectos relativos a cultura política e ideologia que podem influenciar a deliberação, como sugerem Janssen e Kies (2005). Um deles é a existência de diferenças culturais entre regiões. No caso das páginas analisadas neste estudo, verificamos que, em sua maioria, os participantes dos debates sobre políticas culturais são moradores do Distrito Federal sobretudo artistas, produtores culturais e outros profissionais com interesse por assuntos relativos a patrimônio e preservação cultural - distribuídos entre diferentes regiões administrativas e com diferentes características socioeconômicas e de acesso ao poder 
público.

Essa última característica nos chamou atenção logo na primeira etapa do estudo (avaliação sobre a interação entre as fanpages), quando identificamos por meio do mapeamento de redes em mídias digitais (Figura 3) que alguns grupos de fanpages administradas por actantes da sociedade civil se distanciavam de outros grupos formados por páginas gerenciadas por entes do poder público.

Nesse sentido, observamos com maior atenção as redes formadas por artistas urbanos, principalmente artistas de rua, com o propósito de entender essa dinâmica. Nesse ponto, as entrevistas realizadas com o segmento artístico e com gestores públicos foi fundamental e pudemos observar a influência do aspecto da diferença cultural a articulação das redes e sobre a participação social pela internet. Quando questionamos seguidores e administradores das fanpages sobre as oportunidades em que tentaram interagir com o Estado por meio da internet, a resposta imediata foi de resistência quanto aos representantes do Estado e descrédito quanto à possibilidade de obter resultados em termos de políticas públicas.

O Estado pouco intervém, não há esse interesse [de diálogo do poder público com os artistas de rua], não vejo interesse do governo em promover políticas sociais para tal grupo. (Pedro Solsidan, grafiteiro e administrador da fanpage Arte Rua DF, em entrevista realizada no dia 28/11/2016.)

Nos chamou atenção ainda que, mesmo acompanhando páginas oficiais do poder público (um movimento que também apareceu na etapa de mapeamento das redes em mídias digitais e formação de comunidades), há um maior esforço de actantes da sociedade civil em debater, agir politicamente e obter resultados para conflitos a partir de discussões com outros atores sociais que por meio do diálogo com representantes do Estado na internet:

\footnotetext{
Não participo de discussões em páginas oficiais, até mesmo porque sei que quem responde são os assessores. Muitas vezes os senadores e deputados ou os "oficiais" nem sabem o que estão falando em seu nome. Acho falso e creio que produz pouco efeito. É muito mais fachada do que qualquer outra coisa. Claro que existem exceções, mas na grande maioria é assim que funciona. Para ser bem sincera, às vezes acho perda de tempo participar dessas páginas. (Rita Andrade, diretora de produção cultural e audiovisual e seguidora das fanpages Rádio Cultura FM - 100,9 e Secretaria de Cultura do Distrito Federal, em entrevista realizada no dia 19/11/2016.)
}

É interessante observar ainda o olhar de representantes do Estado sobre esse movimento: 
Os artistas de rua nunca tiveram nenhuma atenção do poder público, então é natural que eles se articulem entre eles e não acreditem que virá qualquer coisa do poder público que favoreça a vida deles. A gente está super atento a isso. A gente não consegue fazer tudo ao mesmo tempo, mas já está no Jurídico da Secretaria de Cultura a proposta de uma lei para os artistas de rua. As linhas do FAC estão se aproximando cada vez mais e eu acredito que a partir do ano que vem a gente vai conseguir sim conversar com os artistas de rua, com o artista do circo, que são setores mais marginalizados em termos de política pública, e é natural que eles se articulem sem o poder público porque o poder público não olha para eles. (Guilherme Reis, secretário de Cultura do Distrito Federal, em entrevista realizada no dia 14/11/2016.)

Quanto ao tipo de ator político a hospedar o debate, cabe pontuar que todas as páginas analisadas são hospedadas em plataforma da corporação privada Facebook Inc., que tem a liberdade de dar maior ou menor impulso às publicações e até omitir tópicos para alguns usuários sem o consentimento explícito dos administradores de conteúdo, sejam eles actantes da sociedade civil ou entes do poder público.

Isso foi observado por alguns administradores de fanpages durante as entrevistas no âmbito deste estudo como uma limitação do uso de mídias e redes digitais para o debate de assuntos de interesse público.

O ruim do Facebook é que você pode ter um público muito grande, como no caso de órgãos públicos como a Câmara [Legislativa], mas ele restringe o alcance. E a gente viu que estava com dificuldade de crescer muito sem a questão dos anúncios. Porque a plataforma te coloca em uma situação que você tem que começar a pagar e aí você vai desenvolver a sua página. (Bruno Sodré, chefe da Seção de Divulgação da CLDF e um dos administradores da fanpage Câmara Legislativa do Distrito Federal, em entrevista realizada no dia 27/10/2016.)

Quanto ao aspecto ideologia dos participantes, cabe destacar que o perfil dos seguidores das fanpages analisadas neste estudo é muito diverso, não sendo possível definir com clareza a influência do posicionamento político sobre o debate geral.

Por fim, no que se refere ao tópico de debate, sendo os assuntos em pauta relativos a políticas culturais no Distrito Federal, foi possível observar que os participantes das fanpages apresentam características muito diversas quanto a gênero, local de moradia entre as regiões administrativas, nível socioeconômico, escolaridade e faixa etária, entre outros aspectos, o que nos parece interesse no ponto de vista de abertura da ação pública para agendas, agências e agentes diversos.

\subsubsection{Avaliação de design e conteúdo das páginas selecionadas}


No que se refere à funcionalidade, as páginas hospedadas na plataforma Facebook possuem, de maneira geral, a mesma estrutura pensada para facilitar a navegação e a leitura rápida, bem como possibilitar a interação e a articulação com outros aspectos da vida do usuário, que pode, ao mesmo tempo em que debate assuntos de interesse coletivo, acompanhar notícias, visualizar fotos de família e conversar com outros usuários sobre assuntos diversos.

Com o auxílio de profissionais e a partir de ferramentas pagas oferecidas pela Facebook Inc., é possível aprimorar as experiências de utilização das fanpages. No caso das páginas analisadas neste estudo, a maior parte trabalha dentro dos mesmos padrões de funcionalidade com os elementos básicos destinados a usuários que não fazem uso de recursos extras pagos.

Quanto ao conteúdo, em geral as páginas trabalham com publicações de textos curtos de linguagem simples e coloquial sempre acompanhados por imagens, vídeos, links e outros recursos multimídia que despertam maior atenção dos usuários e possuem maior alcance de público a partir da organização dos algoritmos definidos pelos programadores da Facebook Inc.

Cabe fazer um destaque, no entanto, para as páginas da Câmara Legislativa do Distrito Federal, TJDFT - Tribunal de Justiça do Distrito Federal e dos Territórios e Ministério Público do Distrito Federal e Territórios - MPDFT que, diferente das demais, trabalham com linguagem mais técnica e, por vezes, até rebuscada, no caso das duas últimas. No primeiro caso, foram relatadas questões como cultura organizacional e carência de recursos materiais e de pessoal para tal comportamento. Nos dois últimos casos não foi possível encontrar elementos para compreensão da escolha de linguagem, uma vez que, mesmo com reiteradas tentativas, os administradores das fanpages não se dispuseram a participar deste estudo por meio da concessão de entrevista.

\subsubsection{Análise do processo discursivo nas fanpages}

A análise do processo discursivo proposta por Dahlberg (2002) e descrita no modelo de apreensão deliberativa de Sampaio (2012) foi uma das etapas que mais nos despertou a atenção nesta investigação sobre democracia digital. 
Inicialmente, cabe destacar que muitas páginas criadas para discussão de políticas públicas e selecionadas neste estudo foram alimentadas apenas por um ou dois anos, como é o caso da SOS Cultura Santa Maria - DF, Rede de cultura Planaltina DF e Prefeitura de Brasília, sendo esta última uma página de caráter humorístico.

Logo no primeiro tópico de análise do processo discursivo, tematização e crítica racional (DAHLBERG, 2002), observamos comportamentos curiosos no processo de discussão de políticas culturais pela internet. Nas fanpages de fóruns administradas por actantes da sociedade civil, por exemplo, observamos que os tópicos iniciados pelos administradores das páginas não costumam ser debatidos criticamente no canal, há baixa reciprocidade e a comunicação é basicamente monológica, com apenas algumas reações de demonstração de sentimento quanto ao conteúdo da publicação. Embora as mensagens alcancem certa quantidade de pessoas interessadas na discussão dos temas ali propostos, as postagens não costumam ser comentadas e, quando são, não estão apoiadas em argumentos ou fatos, ficando os comentários apenas no nível posição.

A exceção que observamos a esse padrão das páginas administradas por actantes da sociedade civil foi a fanpage Urbanistas por Brasília, onde a interação é intensa e nos comentários, além de posição há justificação interna e externa, ou seja, os usuários utilizam tanto valores, histórico e testemunhos pessoais para apoiar seus argumentos como fontes externas, dados, notícias e conhecimento técnico, dado que boa parte dos seguidores da página é arquiteto ou urbanista.

Entre as páginas administradas por entes do poder público, a fanpage Governo de Brasília também fugiu do padrão de baixa interatividade e reciprocidade registrado na maior parte das fanpages, tendo sido observada alta interação e continuidade nos debates, com justificação interna na maior parte dos comentários.

No que se refere ao critério reflexividade (DAHLBERG, 2002), observamos que tanto nas páginas administradas por actantes da sociedade civil como nas fanpages gerenciadas por entes do poder público os comentários de publicações com os temas selecionados seguiram para a persuasão (JENSEN, 2003) a partir dos tópicos iniciados pelos administradores e, em alguns casos, a partir de comentários de outros participantes da fanpage. Uma possível explicação para tal comportamento pode estar em algo que foi repetido por diversos actantes na etapa de entrevistas, ocasião em que disseram optar por seguir fanpages com as quais têm afinidade ideológica. Dessa forma, foram registrados 
poucos casos de radicalização, mas também poucos casos de progresso na troca de mensagens, sem indicação de que o debate provocou algum tipo de reflexão dos participantes.

Dentro do critério ideal role Taking (DAHLBERG, 2002), que envolve a escuta e a atenção às colocações dos outros participantes, pudemos observar que, em geral, não há continuidade nos tópicos iniciados pelos administradores e nos comentários, que são poucos se comparados à quantidade de seguidores das fanpages. Na maior parte dos comentários, há respeito implícito e alguns casos de respeito explícito em fanpages administradas por actantes da sociedade civil, mas também foram registrados casos de mensagem sem respeito no nível rude, ou seja, com ofensas e ironias, porém sem registros consideráveis de discursos de ódio ou ataques a princípios democráticos.

No que se refere a inclusão e igualdade discursiva (DAHLBERG, 2002), cabe destacar que o Distrito Federal possui uma das maiores taxas de acesso a internet do país. A Pesquisa Nacional por Amostra de Domicílios (PNAD) de 2013, divulgada pelo Instituto Brasileiro de Geografia e Estatística em 2015 (IBGE, 2015) apontou que em 86\% dos domicílios no DF há acesso a internet banda larga fixa e em 48,9\% há acesso a banda larga móvel. Os números estão acima da média nacional, onde $77,1 \%$ dos domicílios têm conexão por banda larga fixa e 43,5\% têm acesso à banda larga móvel.

Ainda em atenção ao aspecto igualdade discursiva, observamos que em muitas fanpages, sobretudo nas páginas administradas por actantes da sociedade civil, há usuários ou participantes que dominam as discussões, sendo mais atuantes na publicação de comentários e obtendo maior retorno de outros seguidores que os demais. Não fica claro na observação do comportamento digital a que se deve tal diferença, mas a partir da observação de reuniões, do contato com movimentos culturais da região e por meio das entrevistas realizadas com actantes seguidores e administradores de fanpages foi possível observar a valorização dos actantes do segmento cultural a aspectos como reconhecimento público, histórico pessoal, capacidade de articulação política e atuação em encontros presenciais com outros actantes das redes, mostrando que há dentro delas diferenças de força entre as conexões, com elos mais fortes e elos mais fracos.

Por fim, analisando o critério autonomia do Estado e do poder econômico (DAHLBERG, 2002), observamos que embora as páginas estejam hospedadas na plataforma de uma corporação privada e o conteúdo nas fanpages selecionadas neste 
estudo, em alguns casos, seja administrado por actantes da sociedade civil e, em outros, por entes estatais, há registros de alta e baixa deliberatividade em ambas. Em algumas páginas, como relataram entrevistados, o respaldo para a discussão está justamente na ausência do poder institucional, e em outras o debate é fomentado pela possibilidade de resposta do Estado, como na fanpage do Governo de Brasília.

\subsubsection{Concepção dos actantes sobre deliberação e participação social pela internet}

Estudos desenvolvidos por teóricos contemporâneos da democracia indicam que "as pessoas participam de iniciativas quando as consideram uma oportunidade adequada para atingir fins desejáveis" (MAIA; GOMES; MARQUES, 2011, p. 30-31) e, nesse sentido, iniciativas digitais democraticamente relevantes seriam aquelas com propósitos como o fortalecimento da capacidade concorrencial da cidadania, o reforço de uma sociedade de direitos e a promoção da diversidade de agentes, agências e agendas na esfera pública e nas instâncias de decisão.

\footnotetext{
Assim, faz parte do sistema de produção da democracia digital fazer com que iniciativas (meios) sejam vistas como oportunidades vantajosas para os que dela participem. Como isso é possível? Iniciativas precisam incluir cálculos de eficiência ou efetividade. Uma iniciativa como um orçamento digital, por exemplo, só se converte numa real oportunidade se, de fato, assegurar que os resultados da participação produzam efeitos sobre o orçamento público e/ou sobre políticas orçamentárias. Caso contrário, ela será, ao menos em parte, artimanha do sistema político para legitimar as suas decisões jogando para o público. (MAIA; GOMES; MARQUES, 2011, p. 31)
}

No decorrer desta pesquisa, observamos que, embora exista entre os actantes das redes analisadas a concepção de um potencial positivo da internet para o incremento da democracia, uma série de desafios ainda se impõe à efetivação do ambiente online como uma possibilidade real de reafirmação da soberania popular dentro dos moldes de gestão pública em vigor no país e no Distrito Federal.

Não é possível pensar em gestão de comunicação organizacional ou mesmo gestão governamental sem levar em consideração o diálogo com a sociedade civil e a transparência dos trâmites públicos. As ferramentas digitais, desde o Portal de Transparência, Lei de Acesso à Informação e ouvidoria até as redes sociais, são indispensáveis para que se fortaleça o processo democrático que deve reger a nossa sociedade. O governo tem que estar a serviço do cidadão. A tecnologia modifica essa interação, os modos de ser do cidadão também já modificados pela sua relação com a tecnologia que configura essa nova instância interativa. (Guilherme Lobão, assessor de comunicação e administrador da fanpage da Secretaria de Cultura do Distrito Federal, em entrevista realizada no 
dia 10/11/2016.)

Entre os administradores de páginas vinculadas a órgãos públicos e gestores públicos entrevistados neste estudo, prevaleceu a ideia de que o uso da internet e de redes sociais articuladas no ambiente digital é algo muito recente em todo o mundo, o que ainda provoca certo ceticismo de autoridades públicas e representantes do Estado.

\begin{abstract}
As redes sociais hoje cumprem uma tarefa muito bacana na democratização da informação, mas também trazem o que se chama de trash, o lixo da internet vem junto com isso tudo. Então as discussões às vezes são prejudicadas por distorções, por opiniões e não por uma ação coletiva [...]. Você vê que ali tem uma sujeira, um ruído na discussão, que poderia ser muito bacana, talvez uma contribuição de pensamento muito interessante. Então você tem que filtrar, coar, separar o joio do trigo para, dentro daquela discussão, falar "aqui tem uma proposta bacana, tem uma pessoa interessada que pode ajudar numa discussão". É muita desinformação. Esse é o risco de a gente se estruturar enquanto categorias via redes sociais. Acho que o contato presencial é fundamental, a discussão amadurecida é fundamental pensando em política de Estado. (Guilherme Reis, secretário de Cultura do Distrito Federal, em entrevista realizada no dia 14/11/2016.)
\end{abstract}

Foi demonstrada também uma preocupação quanto à qualidade do debate desenvolvido no ambiente digital:

\begin{abstract}
Não sei se é só o meu [perfil na plataforma Facebook], mas a impressão que tenho é que as pessoas estão discutindo muito mais política, direita e esquerda se batendo. Então eu acho que a rede social e a internet aumentaram muito essa discussão. A minha impressão é que ou o ambiente político é outro ou a internet talvez tenha colaborado para isso. Só que eu fico pensando até que ponto esse debate massificado não o tornou mais raso, até porque muita coisa você pode colocar em um meme ${ }^{20}$ e tal. Mas também você vê cada vez mais as pessoas se engajando em discussões. Eu não vejo a nossa página sendo um elemento catalisador disso aí, mas eu vejo que a internet é um ambiente propício para isso. Só que aí por ser uma coisa mais rasa, facilita algumas coisas como discurso de ódio, intolerância. E até por você não estar frente a frente com as pessoas, libera os sentimentos. Aí você vê a discussão na internet, mas será que isso está chegando na rua? Tem uma insatisfação muito grande, mas eu não sei até que ponto a pessoa já se dá por satisfeita de botar aquela insatisfação para fora na rede social e, de alguma forma, algumas pessoas vão ler e aí não precisa colocar a cara a tapa no presencial. (Bruno Sodré, chefe da Seção de Divulgação da CLDF e um dos administradores da fanpage Câmara Legislativa do Distrito Federal, em entrevista realizada no dia 27/10/2016.)
\end{abstract}

Alguns gestores também ressaltaram que, embora ainda não dê espaço a todos, a internet ampliou as possibilidades de fala para além dos grupos historicamente privilegiados:

20 Meme é um termo utilizado na internet que se refere ao fenômeno de viralização de uma informação, ou seja, qualquer vídeo, imagem, frase ou outro conteúdo que se espalha entre vários usuários rapidamente, alcançando alta popularidade. 


\begin{abstract}
A internet é um espaço político em que, preservadas as devidas proporções, todos e todas que a ela têm acesso possuem um espaço de fala. E isso assusta a elite, aqueles que antes tinham esse espaço de forma quase exclusiva. Sabemos que a internet ainda não atinge a todos e todas, mas estamos caminhando para uma democratização desses lócus e os movimentos dela originários têm sido cada vez mais fortes. Não é o único espaço, mas definitivamente é um espaço interessante para a participação política, com um crescimento vertiginoso nos últimos anos. (Joceline Gomes, gerente de Comunicação para a Diversidade da Secretaria de Cultura do Distrito Federal e administradora da fanpage Subsecretaria de Cidadania e Diversidade Cultural, em entrevista realizada no dia 09/11/2016.)
\end{abstract}

Observamos ainda entre os órgãos públicos certa resistência burocrática e dificuldade para lidar com o tempo de resposta e demais características da internet, materializadas na falta de investimento em recursos humanos e materiais para aprimoramento das iniciativas digitais. De maneira geral, verificamos que as iniciativas de participação social propostas pelo poder público que hoje são desenvolvidas pela internet foram iniciativas de ação presencial com divulgação pela internet, mas que raramente consideram as peculiaridades do meio digital e o comportamento dos atores sociais na internet para sua concepção e para o desenvolvimento de ferramentas adequadas:

\footnotetext{
As redes sociais alcançam muita gente e de várias formas. Tem muita gente que não lê jornal, mas tem redes sociais. Ainda tem governo que não teve essa percepção. Não significa que o que eu postei aqui toda a população vai saber, mas é um dos canais. [...] A maior dificuldade sobre a qual falamos hoje é integração. A área de Tecnologia da Informação, por exemplo. Os profissionais às vezes nem sabem que podem se juntar para fazer uma mesma coisa e não é somente uma questão política, é uma questão de otimizar o sistema. (Adriana Caitano, subchefe de Interação Social do Governo de Brasília e uma das administradoras da fanpage Governo de Brasília, em entrevista realizada no dia 09/11/2016.)
}

Outro ponto que nos chamou muita atenção em diversas etapas deste estudo foi o descrédito de actantes da sociedade civil quanto à possibilidade de alcançar resultados políticos concretos no diálogo com os representantes do Estado por meio de redes sociais articuladas no ambiente digital:

Eu fico mais em uma de... velho, ele [o gestor ou a autoridade pública] nem vai ler isso. Deve ter um assessor que cuida disso e também acho que não tem nada a ver. Eu marco assim "Secretaria de Cultura", boto lá uma hashtag, e mando email. (Naiara Lira, cantora, produtora cultural e seguidora da fanpage Fórum de Produtores Culturais na UnB, em entrevista realizada no dia 03/11/2016.)

Também observamos que as redes articuladas no ambiente digital são concebidas pelos actantes muito mais como apoio para o que é discutido e decidido presencialmente 
do que como um espaço mais propício ao debate e à deliberação, não havendo a substituição de um pelo outro, mas aos poucos, uma adaptação para utilizar os recursos que são mais interessantes no meio digital de forma a facilitar as ações no campo presencial:

\begin{abstract}
Não tenho muito conhecimento desse espaço. Mesmo assim tenho certeza de que o ambiente de contatos presenciais é mais importante. A internet é um recurso para a organização política, assim como os correios e a máquina de escrever foram recursos. Mas imagino que a internet não é o ambiente de organização política. (Carlos Augusto Cacá, poeta, militante do movimento cultural e seguidor da fanpage Fórum de Cultura do DF, em entrevista realizada no dia 28/11/2016.)
\end{abstract}

No entanto, há também entre actantes das redes analisadas uma noção de que a utilização dos recursos e ferramentas disponíveis no ambiente digital pode ser aprimorada:

Hoje em dia a internet é fundamental para qualquer tipo de atividade. Desde o profissional que quer divulgar seu trabalho, a indústria que quer expor seu produto, o governo que quer dar transparência às suas ações. Quem não está na internet não é levado tão a sério, passando uma ideia de desleixo ou incompetência. A participação política por meio da internet é mais ágil, prática e, se for bem planejada e dimensionada com as ferramentas e metodologia corretas, pode envolver a população de uma maneira muito mais eficiente do que somente de forma presencial. (Cristiano Nascimento, arquiteto e urbanista e administrador da fanpage Urbanistas por Brasília, em entrevistada realizada no dia 13/11/2016.)

Algo que apareceu reiteradas vezes nas entrevistas com gestores públicos, administradores e seguidores de fanpages foi uma preocupação quanto à superficialidade do debate desenvolvido na internet e a qualidade da deliberação nesse espaço:

Eu uso rede social, eu olho, mas no quesito conteúdos publicados eu acho pouco interessante. Eu acho que é uma ferramenta excelente, mas muito mal utilizada porque as pessoas que teriam condições de abastecer essas redes com um pensamento mais crítico acabam não participando. Então fica um monte de opiniões. Mais opinião que um pensamento crítico trabalhado. (Luiz Amorim, agitador cultural, idealizador do projeto Parada Cultural e seguidor da fanpage Câmara Legislativa do Distrito Federal, em entrevista realizada no dia 10/11/2016.)

A preocupação também aparece na forma como as redes são formadas e desarticuladas de maneira muito rápida no contexto digital:

Hoje as pessoas têm muita dificuldade de internalizar as coisas, fica tudo muito na ação imediata. A internet motiva as pessoas, mas não tem consistência estratégica e, politicamente, falando em termos de confronto, de teses e posições, é importante que você tenha substrato, que deixe um lastro para que as coisas tenham começo, meio e fim. (Rênio Quintas, maestro e um dos administradores da fanpage Fórum de Cultura do DF, em entrevista realizada no dia 04/11/2016.) 
Contudo, algumas falas e olhares sobre as redes formadas por fanpages de discussão de políticas públicas de cultura no Distrito Federal indicam que tanto uma perspectiva de avanço no uso de recursos digitais para fortalecimento democrático como uma limitação da democracia digital pode estar na forma como as novas tecnologias de informação e comunicação e espaços abertos por esse novo contexto têm sido utilizadas pelos diversos actantes, sejam eles representantes do Estado, atores sociais ou entes privados em disputa no modelo de democracia liberal contemporâneo:

\begin{abstract}
[A participação política pela internet] não só é interessante, como é imprescindível. O mundo é digital, as relações são digitais, o amor pode ser expressado de forma digital também. Um não substitui o outro. Os isolamentos, os excessos e outras relações abusivas digitalmente são o reflexo do usuário e não da ferramenta. (Marina Mara, poeta e seguidora das fanpages Subsecretaria de Cidadania e Diversidade Cultural, Urbanistas por Brasília, Rádio Cultural FM -100,9, entre outras, em entrevista realizada no dia 21/11/2016.)
\end{abstract}

É interessante observar que a análise sobre as redes articuladas com apoio na internet e avaliadas neste estudo aponta que o aprimoramento da democracia digital não depende somente de fatores de ordem tecnológica ou da disponibilização de ferramentas e espaços de participação e deliberação online pelo Estado, mas também de elementos culturais, sociais, políticos e sobretudo, de educação dos diversos usuários no ciberespaço. 


\section{CONSIDERAÇÕES FINAIS}

Acompanhado por mudanças nos contextos político, social, econômico e tecnológico, o amadurecimento democrático brasileiro nas últimas décadas tem demandado formas de participação social que superem os arranjos formais de atuação da sociedade civil "por dentro do Estado", na medida em que os atores sociais têm se reconhecido como mais que meros demandantes de bens e serviços e exigido, sob diferentes aspectos, novas formas de nomeação da realidade, condições de disputa nas estruturas de poder e impacto real no desenvolvimento das políticas públicas.

Se a esfera civil é o âmbito vital da comunidade política democrática e a instância que justifica e legitima a própria democracia, as iniciativas digitais têm ganhado força em um contexto marcado pela perspectiva de inclusão diante do avanço tecnológico em todo o mundo, de forma que surgem novas possibilidades quanto à capacidade de fortalecimento da capacidade concorrencial da cidadania, à consolidação de uma sociedade de direitos, à promoção da pluralidade e à inserção das minorias nas esferas de decisão política. (MAIA; GOMES; MARQUES, 2011).

As políticas públicas de cultura no país têm sido campo fértil para essa remodelagem dos formatos participativos em um novo olhar sobre o desenvolvimento e, no Distrito Federal, a articulação de artistas e produtores culturais em redes orientadas para promover a formação de sujeitos capazes de provocar impacto nas práticas políticas nos oferece um valioso material de estudo.

A luta pelo direito cultural na região tem sido fortemente influenciada pelas novas tecnologias de informação e comunicação. Comunidades virtuais têm se multiplicado entre a sociedade civil e é ainda incipiente o seu diálogo com o poder público no ambiente digital, embora a articulação facilitada pela internet apresente resultados positivos a serem encaminhados no campo presencial, um fenômeno que ilustra a tendência de um novo formato organizacional da sociedade civil em seu papel de controle e acompanhamento das políticas, atribuindo um novo caráter à ação pública.

Se, por um lado, verificamos que as mídias digitais têm possibilitado uma atuação política diferente daquela operacionalizada sob a lógica tradicional, propiciando condições para a ocorrência de fenômenos como maior interatividade, liberdade de discurso, multiplicidade de vozes e publicação instantânea de conteúdos a baixo custo, por outro é ainda um desafio o aproveitamento efetivo do uso da internet para fins de participação nas 
decisões e discussões públicas, uma vez que este estudo observa limitada cultura e educação política para o debate, além de um esforço do Estado pela centralização das discussões em canais oficiais, o que parece ir na contramão dos fluxos do ciberespaço, um campo notadamente marcado pela horizontalidade e diversidade de pontos de emissão de mensagens.

Ressalta-se aqui que já é possível observar um potencial subutilizado de uso e monitoramento de mídias digitais para fins de interesse público, o que aparece neste estudo com os relatos de baixo ou nulo investimento em recursos humanos e materiais para este fim dentre os órgãos públicos vinculados aos três poderes locais. Se, por um lado, é salutar no ambiente digital o avanço das interações entre sociedade civil e empresas do setor privado ou personalidades políticas em período eleitoral, é ainda limitado o diálogo de atores da sociedade civil e poder público, dado que a interação se mostra mais fortalecida entre os próprios atores sociais para fins de articulação que destes com o Estado no intuito de solução de impasses e aprimoramento das práticas políticas.

Scherer-Warren (2008, p. 513) destaca que "as novas tecnologias, especialmente a internet e as rádios comunitárias, são um elemento facilitador na difusão das narrativas e ideários em construção pelos sujeitos, nós das redes", sobretudo em decorrência de sua agilidade e amplitude. Sua observação é pertinente ao avaliarmos neste estudo de caso que, além da mobilização com ênfase nas relações com o Estado para controle das políticas públicas de cultura, as ferramentas de comunicação digital têm sido utilizadas também com a finalidade de construção de soluções pelos próprios atores sociais muitas vezes até sem a participação direta do Estado, seja por meio do compartilhamento de experiências ou da discussão de temas não especificamente ligados às políticas culturais, mas também propiciadores de formação política, como combate à corrupção, preservação do meioambiente, fortalecimento da educação, promoção da assistência social e garantia de direitos.

Novas indagações surgem das observações que expusemos nestas páginas. Seriam interesses diferentes aqueles apresentados pelos atores da sociedade civil e os que partem dos entes estatais? O esforço das autoridades públicas, no que se refere à internet e ao emprego de ferramentas compatíveis com ela, estaria mais voltado à publicidade de suas ações que a uma abertura à esfera civil no jogo democrático? Estamos dando a devida atenção aos traços digitais que deixamos nas interações em sites e comunidades virtuais? 
Que uso as grandes corporações e o Estado podem fazer e estão realmente a fazer deles?

Os instrumentos de pesquisa selecionados para esta investigação se complementam no esforço de seguir alguns desses traços deixados pelas interações, como propõe a abordagem metodológica da Teoria Ator-Rede. Se o mapeamento das fanpages nos ofereceu os lastros iniciais para a observação do comportamento dos atores em estudo, o modelo de apreensão deliberativa, com o apoio de entrevistas, apresenttou os critérios a serem analisados no que se refere a perspectivas e desafios da democracia digital.

Um exemplo claro desse movimento foi observado na relação entre artistas de rua e entes estatais. A falta de comunicação verificada no mapeamento das redes nas fases iniciais do estudo nos levou às perguntas mais tarde empregadas no olhar sobre aspectos referentes a diferenças culturais e ideológicas e seu impacto sobre a deliberação, mais uma vez buscando na Teoria Ator-Rede a perspectiva de estudo que se vale das associações e dissociações.

Também observamos que a mobilização por canais virtuais não tem impedido ou reduzido o esforço pela realização de encontros presenciais entre os atores-rede, "pois neles é onde ocorre o debate mais profundo, a experiência da prática política e os vínculos mais duradouros no interior da rede.” (SCHERER-WARREN, 2008, p. 514).

Enquanto fenômeno interdisciplinar e fluido, a compreensão das redes nos exigiu uma análise dinâmica da trajetória dos atores e dos traços construídos pela interação e, nesse sentido, uma controvérsia que impôs maior dinamismo metodológico a este estudo refere-se ao fato de que os participantes constroem e modificam sua avaliação sobre a formação dos grupos, sobre seu caminho individual e sobre a interação com os demais atores, sejam eles humanos ou não-humanos, como no caso em questão, no qual analisamos, entre outros aspectos, a influência das novas tecnologias de informação e comunicação sobre as interações da rede.

Ao mesmo tempo em que as redes apontam algumas fragilidades ao se apresentarem, muitas vezes, como alternativa aos espaços formalmente instituídos, ampliando as possibilidades de fragmentação, dada a inclusão de novos atores, observamos alguns sinais de que elas também operam em um sentido de emancipação, superando a lógica de reivindicação individual para a construção de sujeitos sociais dotados de valores diversos.

Nessa observação aparece outro importante desafio quanto à capacidade de 
articulação das diferentes redes no sentido de legitimarem pautas passíveis de deliberação no âmbito público, dado que as divergências naturais de sujeitos políticos e desigualdades, em seus diferentes aspectos, parecem afastar os diferentes atores e colocá-los em confronto no lugar de promover a articulação entre eles.

Por fim, cabe ressaltar que este estudo não tem a pretensão de ser conclusivo quanto a tantas questões que permeiam a democracia digital em suas limitações e perspectivas. Os resultados que apresentamos aqui são avaliações sobre elementos que observamos durante o período de pesquisa no caso da articulação de redes de artistas e produtores culturais do Distrito Federal para fins de participação nas políticas públicas, destacando sobretudo as experiências do percurso metodológico que podem servir para estudos futuros.

Nesse ponto, sublinhamos um desafio teórico importante para novas investigações sobre democracia digital. O esforço democrático por ideais de igualdade e liberdade precisa lidar também com o reconhecimento das desigualdades, da diversidade de valores dos sujeitos e das discrepâncias de poder entre os actantes que, como observamos neste estudo, permanecem e, muitas vezes, são até potencializadas na articulação de redes e no contexto da cibercultura. Se as reflexões da democracia deliberativa nos oferecem aspectos normativos de análise do quão distantes estamos do modelo dito ideal de exercício cívico, temos agora, enquanto pesquisadores, o desafio de apresentar novas contribuições teóricas e críticas a esse debate. 


\section{REFERÊNCIAS}

AVRITZER, L.; COSTA, S. Teoria crítica, democracia e esfera pública: concepções e usos na América Latina. In: DADOS: Revista de Ciências Sociais, Rio de Janeiro, v. 47, no 4, p.703-728 2004.

Sociedade civil, instituições participativas e representação: da autorização à legitimidade da ação. In: DADOS - Revista de Ciências Sociais, v. 50, n. 3. Rio de Janeiro: UERJ, 2007, p. 443-464.

BASTOS, G. S.; RECUERO, R. Encontros e desencontros entre TAR e ARS: o laço fraco entre teoria e método. Contemporânea (UFBA Online), v. 12, p. 1-15, 2014.

BAUMAN, Z. Modernidade líquida. Rio de Janeiro: Zahar, 2001.

Legisladores e intérpretes. Rio de Janeiro: Zahar, 2010.

A cultura no mundo líquido moderno. Rio de Janeiro: Zahar, 2013.

BOBBIO. N. Dicionário de política. Brasília: Editora Universidade de Brasília, 1998.

BRASIL. Constituição (1988). Constituição da República Federativa do Brasil. Brasília, DF: Presidência da República. Disponível em <http://www.planalto.gov.br/ccivil_03/constituicao/constituicaocompilado.htm>. Acesso em: 21 jan. 2017.

Constituição (1988). Emenda Constitucional n ${ }^{\circ} 71$, de 29 de novembro de 2012. Acrescenta o art. 216-A à Constituição Federal para instituir o Sistema Nacional de Cultura. In: BRASIL. Constituição (1988). Constituição da República Federativa do Brasil. Brasília, DF: Presidência da República. Disponível em <http://www.planalto.gov.br/ccivil_03/constituicao/constituicaocompilado.htm>. Acesso em: 21 jan. 2017.

Lei $n^{\circ} 12.965 / 2014$ - Estabelece princípios, garantias, direitos e deveres para o uso da Internet no Brasil.

Decreto ${ }^{\circ} 8.771 / 2016$ - Regulamenta a Lei n 12.965 , de 23 de abril de 2014, para tratar das hipóteses admitidas de discriminação de pacotes de dados na internet e de degradação de tráfego, indicar procedimentos para guarda e proteção de dados por provedores de conexão e de aplicações, apontar medidas de transparência na requisição de dados cadastrais pela administração pública e estabelecer parâmetros para fiscalização e apuração de infrações.

.Lei $\mathrm{n}^{\circ} 12.737 / 2012$ - Dispõe sobre a tipificação criminal de delitos informáticos; altera o Decreto-Lei n ${ }^{\circ}$ 2.848, de 7 de dezembro de 1940 - Código Penal; e dá outras providências. 
Lei $n^{\circ}$ 12.343/2010 - Institui o Plano Nacional de Cultura - PNC, cria o Sistema Nacional de Informações e Indicadores Culturais - SNIIC e dá outras providências.

As Metas do Plano Nacional de Cultura/2011/MinC. Disponível em: <http://www.cultura.gov.br/documents/10883/11294/METAS_PNC_final.pdf//>. Acesso em: 01 fev. 2017.

. Decreto $\mathrm{n}^{\circ}$ 5.520/2005 - Institui o Sistema Federal de Cultura - SFC e dispõe sobre a composição e o funcionamento do Conselho Nacional de Política Cultural - CNPC do Ministério da Cultura, e dá outras providências.

Decreto $n^{\circ}$ 6.973/2009 - Altera o Decreto $n^{\circ}$ 5.520, de 24 de agosto de 2005, que institui o Sistema Federal de Cultura - SFC e dispõe sobre a composição e o funcionamento do Conselho Nacional de Política Cultural - CNPC do Ministério da Cultura.

Portaria n $^{\circ}$ 28/2010/MinC - Publica Regimento Interno do Conselho Nacional de Política Cultural.

BRUNO, F. Rastros digitais sob a perspectiva da Teoria Ator-Rede. Revista FAMECOS: mídia, cultura e tecnologia, v. 19, n. 3, p. 681-704, 2012.

CALABRE, Lia. Políticas culturais no Brasil: dos anos 1930 ao século XXI. Rio de Janeiro: Editora FGV, 2009.

CARMO, Cleide Mara Vilela do. Instrumentos e políticas públicas de cultura: o caso dos editais do Fundo de Apoio à Cultura do Distrito Federal no período de 2011 a 2014. Dissertação (Mestrado em Desenvolvimento, Sociedade e Cooperação Internacional) Programa de Pós-Graduação em Desenvolvimento, Sociedade e Cooperação Internacional, Universidade de Brasília, Brasília, 2016.

CASTELLS, M. A sociedade em rede - a era da informação: economia, sociedade e cultura. Trad. Roneide Venâncio Majer e Jussara Simões. $8^{a}$ edição. São Paulo: Paz e Terra, 1999.

Entrevista concedida a Paul Mason e publicada na Revista Fórum Online em 28 de novembro de 2012. Disponível em: <http://revistaforum.com.br/blog/2012/11/castells-veexpansao-do-nao-capitalismo/>. Acesso em 06 mar. 2017.

Redes de indignação e esperança - movimentos sociais na era da internet. Trad. Carlos Alberto Medeiros. Rio de Janeiro: Zahar, 2013.

CGI. Pesquisa sobre o uso das tecnologias da informação e comunicação no setor público brasileiro: TIC Governo Eletrônico 2013/ Survey on the use of information and communication technologies in the Brazilian public sector:ICT Electronic Government 2013. São Paulo: Comitê Gestor da Internet no Brasil, 2014. Disponível em <http://cetic.br/media/docs/publicacoes/2/TIC_eGOV_2013_LIVRO_ELETRONICO.pdf> . Acesso em: 12 mar. 2017. 
Pesquisa sobre o uso de tecnologias de informação e comunicação no setor público brasileiro: TIC Governo Eletrônico 2015/ Survey on the use of information and communication technologies in the Brazilian public sector: ICT Electronic Goverment 2015. São Paulo: Comitê Gestor da Internet no Brasil, 2016. Disponivel em: <http://cetic.br/media/docs/publicacoes/2/TIC_eGOV_2015_LIVRO_ELETRONICO.pdf> . Acesso em: 12 mar. 2017.

COHEN, J.; FUNG, A. Radical democracy. Swiss Journal of Political Science, Saint Gallen, v. 10, n. 4, p. 23-34, 2004.

COSTA, A. C. Redes sociais: estratégias de monitoramento. Rio de Janeiro: Novaterra, 2015.

CRESWELL, J. W. Projetos de pesquisa: modelos qualitativos, quantitativos e mistos. Porto Alegre: Artmed, 2007.

DAGNINO, E. Confluência perversa, deslocamentos de sentido, crise discursiva. In: GRIMSON, A. (org.). La cultura en las crisis latinoamericanas. Buenos Aires: CLACSO, 2004, p. 195-216.

Sociedade civil, participação e cidadania: de que estamos falando. In: Políticas de ciudadanía y sociedad civil en tiempos de globalización.Caracas: FACES, Universidad Central de Venezuela, 2004a, p. 95-110.

DAHLBERG, L. Extending the Public Sphere through Cyberspace: The Case of Minnesota E-Democracy. First Monday, London, v. 6, n. 3, p. 147-163, 2001.

Net-public sphere research: beyond the 'first phase'. In: Euricom Colloquium: Electronic Networks and Democracy, The Neverlands, n. 14, p. 1-14, 2002.

DAVIS, R. Politics online: blogs, chatrooms and discussion groups in american democracy. New York: Routledge, 2005.

DISTRITO FEDERAL, Decreto n ${ }^{\circ}$ 20.264/1999 - Dispõe sobre a extinção da Fundação Cultural do Distrito Federal e a reestruturação da Secretaria de Cultura do Distrito Federal, na forma da Lei $\mathrm{n}^{\mathrm{o}} 2.294$, de 21 de janeiro de 1999. Cultura - PAC.

Lei Complementar no 267/1999 - Dispõe sobre a criação de Programa de Apoio à Lei no 49/1989 - Altera a estrutura da administração do Distrito Federal, extingue órgãos e dá outras providências.

Lei no 111/1990 - Estabelece a competência, composição e classificação do Conselho de Cultura do Distrito Federal, e dá outras providências.

. Emenda à Lei Orgânica n ${ }^{\circ} 52 / 2008$ - Acrescenta os $\S \S 4^{\circ}$ e $5^{\circ}$ ao art. 246 da Lei Orgânica do Distrito Federal. 
. Decreto no 31.414/2010 - Aprova o Regulamento do Fundo de Apoio à Cultura e o Regimento Interno do Conselho de Administração do Fundo de Apoio à Cultura e dá outras providências.

Decreto no 31.660/2010 - Altera o Decreto no 31.414, de 11 de março de 2010, e dá outras providências.

Decreto $n^{\circ} 34.122 / 2013$ - Altera o Regulamento do Fundo de Apoio à Cultura, aprovado pelo Decreto n ${ }^{\circ} 31.414$, de 11 de março de 2010.

ENRÍQUEZ, M. A. Trajetórias do desenvolvimento: da ilusão do crescimento ao imperativo da sustentabilidade. Rio de Janeiro: Garamond, 2010.

FLICK, U. Introdução à metodologia de pesquisa. Porto Alegre: Editora Penso, 2002.

Uma introdução à pesquisa qualitativa. Porto Alegre: Bookman, 2004.

FUNG, A. Receitas para esferas públicas: oito desenhos institucionais e suas consequências. In: COELHO, V.; NOBRE, M. Participação e deliberação: teoria democrática e experiências institucionais no Brasil contemporâneo. São Paulo: Editora 34, 2004, p. 173-209.

GARROSSINI, D. F. As tecnologias da Informação e Comunicação como vetores catalisadores de participação cidadão na construção de políticas públicas: o caso dos conselhos de saúde brasileiros. Tese (Doutorado) - Faculdade de Comunicação. Universidade de Brasília, Brasília, 2010.

GIADERLLI, G. Você é o que você compartilha. E-agora: como aproveitar as oportunidades de vida e trabalho na sociedade em rede. São Paulo: Editora Gente, 2012.

GOMES, W. A democracia digital e o problema da participação civil na decisão política. Revista Fronteiras - Estudos Midiáticos. v. 3, set. 2005, p.214-222.

- Internet e participação política em sociedades democráticas. In: Revista FAMECOS, Porto Alegre, v. 1, n. 27, 2005a.

HABERMAS, J. Soberania popular como procedimento. Novos Estudos, n. 26, março, p. 100-113, 1990.

Direito e democracia: entre facticidade e validade. Trad. de Flávio B. Siebeneichler. Rio de Janeiro: Tempo Brasileiro, 2003.

Mudança estrutural da esfera pública: investigações quanto a uma categoria da sociedade burguesa. Rio de janeiro: Tempo Brasileiro, 1984.

Espaço público e esfera pública política. Raízes biográficas de dois motivos de pensamento, In _. Entre naturalismo e religião: estudos filosóficos. Trad. Flávio B. Siebeneichler. Rio de Janeiro: Tempo Brasileiro, 2007, p. 15-30. 
Verdade e justificação, Trad. Milton Camargo Mota. São Paulo: Loyola, 2004.

HOLANDA, S. B. de. Raízes do Brasil. 26ª ed. São Paulo: Companhia das Letras, 1995.

IBGE. Pesquisa Nacional por Amostra de Domicílios: Síntese de Indicadores 2013. Coordenação de Trabalho e Rendimento. 2. ed. Rio de Janeiro: IBGE, 2015.

IBGE. Perfil dos estados e dos municípios brasileiros: cultura. Rio de Janeiro: IBGE, 2015a.

JANSSEN, D.; KIES, R. Online forums and deliberative democracy. Acta Política, Basingstoke, n. 40, p. 317-335, 2005.

JENKINS, H. Cultura da convergência. São Paulo: Aleph, 2009.

JENSEN, J. L. Public spheres on the internet: anarchic or government-sponsored - a comparison. Scandinavian Political Studies, Hoboken, v. 26, n. 4, p. 349-374, 2003.

LASCOUMES, P.; LE GALÈS, P. Sociologia da ação pública. Trad. George Sarmento. Maceió: EDUFAL, 2012.

LATOUR, B. Ciência em ação: como seguir cientistas e engenheiros sociedade afora. Trad. Ivone C. Benedetti. 2. ed. São Paulo: Editora UNESP, 2011.

Reagregando o social: uma introdução à teoria do ator-rede. Trad. Gilson César Cardoso de Sousa. Salvador: EDUFBA; Bauru: EDUSC, 2012.

Jamais fomos modernos: ensaio de antropologia simétrica. Trad. Carlos Irineu da Costa. Rio de Janeiro: Ed. 34, 1994.

LAVILLE, C.; DIONNE, J. A construção do saber: manual de metodologia da pesquisa em ciências humanas. Porto Alegre: Artmed; Belo Horizonte: Editora UFMG, 2008.

LEMOS, A. Espaço, mídia locativa e Teoria Ator-Rede. Galáxia (São Paulo. Online), v. 13, p. 52-68, 2013.

LÉVY, P. A emergência do cyberspace e as mutações culturais. Palestra realizada no Festival Usina de Arte e Cultura, promovido pela Prefeitura Municipal de Porto Alegre, em outubro de 1994. Tradução: Suely Rolnik. Revisão da tradução transcrita: João Batista Francisco e Carmem Oliveira. Disponível em: <ww.cin.ufpe.br/ dmn/35.rtf>. Acesso em 03 mar. 2017.

. Cibercultura. Trad. Carlos Irineu da Costa. São Paulo: Editora 34, 1999.

2010. Inteligência coletiva: para uma antropologia do ciberespaço. São Paulo: Editora 34,

LUBENOW, J. A. Esfera pública e democracia deliberativa em Habermas - modelo teórico 
e discursos críticos. In.: Kriterion: Revista de Filosofia, v.51, n.121. Belo Horizonte: Junho de 2010. Disponível em: <http://www.scielo.br/scielo.php?script=sci_arttext\&pid=S0100512X2010000100012\#back31>. Acesso em: 01 fev. 2017.

MACHADO, J. A. Ativismo em rede e conexões identitárias: novas perspectivas para os movimentos sociais. In: Sociologias, v. 9, n. 18. Porto Alegre: UFRGS, julho a dezembro de 2007, p. 248-285.

MACHUY, C. C. de S. Wikipédia midiática: cotidianidades, compilação de saberes e lutas de poder nos bastidores da Enciclopédia livre. Dissertação (Mestrado em Mídia e Cotidiano) - Programa de Pós-Graduação em Mídia e Cotidiano, Universidade Federal $\begin{array}{llll}\text { Fluminense, } & \text { Rio de } & & \end{array}$

MAIA, R. C. M; GOMES, W.; MARQUES, F. P. J. A. (Orgs.). Internet e participação política no Brasil. Porto Alegre: Sulinas, 2011.

MAKIUCHI, M. F. R. (Org.). Políticas culturais, desenvolvimento e construção democrática. Brasília: UnB, 2016.

MALINI, F. O Comunismo das Redes - Sistema Midiático P2P, Colaboração em Rede e Novas Políticas de Comunicação na Internet. Tese de Doutorado apresentada ao Programa de Pós-Graduação em Comunicação e Cultura, da Escola de Comunicação da Universidade Federal do Rio de Janeiro (UFRJ), 2007.

MARQUES, F. P. J. A. Participação política e internet: meios e oportunidades digitais de participação civil na democracia contemporânea, com um estudo do caso do estado brasileiro. Salvador: Tese de doutorado apresentada ao Programa de Pós-Graduação em Comunicação e Cultura Contemporâneas da Universidade Federal da Bahia (UFBA), 2008.

" "Muro baixo, o povo pula": iniciativas institucionais de participação digital e seus desafios fundamentais. In: Revista Opinião Pública, Campinas, vol. 16, nº 1, Junho, 2010, p. $117-142$.

MARTÍNEZ, I. M.; DE ANGELIS, A. La perspectiva cultural em el discurso del desarollo. Revista Iberoamericana de Estudios de Desarollo/ Iberoamerican Journal of Development Studies, v. 2, n. 2, 2013, p. 86-105.

MATA MACHADO, B. N. Os direitos culturais na Constituição brasileira: uma análise conceitual e política. In: CALABRE, Lia (Org.). Políticas culturais: teoria e práxis. São Paulo: Itaú Cultural; Rio de Janeiro: Fundação Casa de Rui Barbosa, 2011.

MINC. Acompanhamento de Metas do Plano Nacional de Cultura. Disponível em $<$ http://pnc.culturadigital.br/metas/plataforma-de-governanca-colaborativa-implementadacomo-instrumento-de-participacao-social-com-100-mil-usuarios-cadastrados-observada-adistribuicao-da-populacao-nas-macrorregioes-do-pais/>. Acesso em: 30 mai. 2016.

MOUFFE, C. El retorno de lo político: comunidad, ciudadanía, pluralismo, democracia radical. Barcelona: Paidós, 1999. 
Por um modelo agonístico de democracia. In: Revista de Sociologia e Política. Curitiba, v. 25, p. 11-23, nov. 2005.

MUTZ, D. C. Hearing the other side: deliberative versus participatory democracy. New York: Cambridge University Press, 2006.

NOGUEIRA, J. P. F. Comunicação pública, internet e democracia: análise de conteúdo do Facebook do Portal Brasil. Trabalho de conclusão de curso (Pós-Graduação em Gestão da Comunicação Organizacional) - Curso de Pós-Graduação Lato Sensu em Gestão da Comunicação Organizacional, Centro Universitário UNICEUB, Brasília, 2014.

OCDE. Promise and Problems of E-Democracy: Challenges of Online Citizen Engagement. Paris: OECD Publications Service, 2003.

OLIVEIRA, N. de. Rawls. Rio de Janeiro: Jorge Zahar Ed., 2003.

OLIVIERI, C. G. Cultura neoliberal: leis de incentivo como política pública de cultura. São Paulo: Escrituras Editora, 2004.

ONU: United Nations E-Government Survey 2012: E-Government for the people. Nova York: United Nations, 2012. Disponível em: https://publicadministration.un.org/egovkb/Portals/egovkb/Documents/un/2012-

Survey/unpan048065.pdf. Acesso em: 07 mar. 2017.

ONU: United Nations E-Government Survey 2014: E-Government for the Future We Want. Nova York: United Nations, 2014. Disponível em: <https://publicadministration.un.org/egovkb/Portals/egovkb/Documents/un/2014Survey/E-Gov_Complete_Survey-2014.pdf/>. Acesso em: 01 fev. 2017.

ORTIZ, R. Cultura brasileira e identidade nacional. São Paulo: Editora Brasiliense, 1985.

PAPACHARISSI, Z. Democracy Online: Civility, Politeness, and the Democratic Potential of Online Political Discussion Groups.New Media \& Society, Thousand Oaks, v. 6, n. 2, p. 259-283, Apr. 2004.

PATEMAN, C. Participação e Teoria Democrática. Rio de Janeiro: Paz e Terra, 1992. March 2012.

Participatory democracy revisited. In: Perspectives on Politics, v. 10, n. 1. p. 7-19,

PAIVA, N. S. G. Planejamento estratégico para as mídias sociais: o uso das novas mídias como ferramenta das relações públicas. Trabalho de conclusão de curso (Graduação em Comunicação Social/ Relações Públicas) - Universidade Federal do Maranhão, São Luís, 2010.

RADOMSKY, G. F. W. Desenvolvimento, Pós-Estruturalismo e Pós-Desenvolvimento: a crítica da modernidade e a emergência de "modernidades" alternativas. Revista Brasileira de Ciências Sociais (RBCS), v. 26, n. 75, p. 149-193, fev. 2011. 
RAWLS, J. Uma teoria da justiça. São Paulo: Martins Fontes, 2011. . Justiça como eqüidade - Uma reformulação. São Paulo: Martins Fontes, 2003.

RECUERO, Raquel. As redes sociais na internet. Porto Alegre: Sulina, 2009.

RECUERO, R.; BASTOS, M.; ZAGO, G. Análise de redes para mídia social. Porto Alegre: Sulina,

2015.

REIS, M. S.; PEIXOTO, L. A. G.; MAKIUCHI, M. F. R. Perspectivas de participação social em rede nas políticas públicas de cultura: a experiência do Fórum de Cultura do Distrito Federal. In: Congresso Internacional Interdisciplinar em Sociais e Humanidades CONINTER, Ano 4, 2015, Foz do Iguaçu, Anais.

RUBIM, A. A. C. Políticas culturais e novos desafios. In: Matrizes. São Paulo, ano 2, n. 2 , primeiro semestre 2009 p. 93-116 Disponível em: <http://www.revistas.usp.br/matrizes/article/view/38226>. Acesso em: 01 fev. 2017.

SAMPAIO, R. C. Participação e deliberação na internet: um estudo de caso do Orçamento Participativo Digital de Belo Horizonte. Dissertação (Mestrado em Comunicação Social). Universidade Federal de Minas Gerais, Belo Horizonte, 2010.

Quão deliberativas são discussões na rede? - Um modelo de apreensão da deliberação online. In: Revista de Sociologia e Política, Curitiba, v. 20, n. 42, p. 121-139, jun.

2012.

SAMPAIO, R. C.; BARROS, S. A. R.; MORAIS, R. Como avaliar a deliberação online? Um mapeamento de critérios relevantes. In: Opinião Pública (UNICAMP, Impresso), v. 18, p. 470-489,

2012a.

SCHERER-WARREN, I. Das mobilizações às redes de movimentos sociais. In: Sociedade e Estado, v. 21, n. 1. Brasília: UnB, janeiro a abril de 2006, p. 109-130.

Redes de movimentos sociais na América Latina - caminhos para uma política emancipatória? In: Caderno CRH, v. 21, n. 54. Salvador: UFBA, setembro a dezembro de 2008 ,

p.

505-517.

SEN, A. Desenvolvimento como liberdade. São Paulo: Companhia das Letras, 2000.

SILVA, S. P. da. Estado, democracia e internet: requisitos democráticos e dimensões analíticas para a interface digital do Estado. Tese (Doutorado em Comunicação e Cultura Contemporâneas) - Programa de Pós-Graduação em Comunicação e Cultura Contemporâneas, Universidade Federal da Bahia, Salvador, 2009.

SOUZA, R. L. S. de. Sobre promessas da era da Internet: Uma análise de mudanças no relacionamento Estado - Sociedade decorrentes da utilização intensiva de tecnologias de comunicação e informação por agentes públicos no Brasil. Dissertação (Doutorado) Faculdade de Comunicação. Universidade de Brasília, Brasília, 2008. 
TATAGIBA, L. Desafios da relação entre movimentos sociais e instituições políticas: o caso do movimento de moradia da cidade de São Paulo - Primeiras reflexões. In: Colombia Internacional, n. 71. Bogotá: Universidad de los Andes, janeiro a junho de 2010, p.

63-83.

TOURAINE, A. O retorno do actor: ensaio sobre Sociologia. Lisboa: Instituto Piaget, $1996 \mathrm{~b}$.

. Iguais e diferentes - Poderemos viver juntos? Lisboa: Instituto Piaget, 1998.

_. Que es la democracia? Ciudad de México: FCE, 2001.

Na fronteira dos movimentos sociais. In.: Sociedade e Estado, Brasília, v. 21, n. 1, p. 17-28, jan./ abr. 2006.

UIT. Measuring the Information Society Report 2015. Geneva: International Telecommunication Union Place des Nations, 2015. Disponível em <http://www.itu.int/en/ITU-D/Statistics/Documents/publications/misr2015/MISR2015w5.pdf>. Acesso em: 27 fev. 2016.

VITALE, D. Between deliberative and participatory democracy: a contribution on Habermas. Philosophy Social Criticism. Londres, v. 32, n. 6, p. 739-766, 2006.

WILHELM, A. Democracy in the Digital Age: Challenges to Political Life in Cyberspace. New York: Routledge, 2000.

WRIGHT, S.; STREET, J. Democracy, Deliberation and Design: The Case of Online Discussion Forums.New Media \& Society, Thousand Oaks, n. 9, p. 849-869, 2007. 


\section{APÊNDICES}

\section{APÊNDICE A - Termo de Consentimento Livre e Esclarecido (TCLE)}

Você está sendo convidado(a) a participar da pesquisa intitulada: Democracia digital e ação pública - experiências de participação social em rede nas políticas de cultura do Distrito Federal, que está sendo realizada pela mestranda Mayara Souza dos Reis, sob orientação da Prof. ${ }^{a}$ Dr. ${ }^{a}$ Maria de Fátima Rodrigues Makiuchi, do Programa de Pós-Graduação em Desenvolvimento, Sociedade e Cooperação Internacional da Universidade de Brasília - UnB.

O objetivo central deste estudo é compreender pontos limitadores e perspectivas para efetivação do potencial de incremento da participação social pela internet e dispositivos de conexão em rede nas decisões de interesse público, de forma que estão sendo analisadas fanpages voltadas à discussão de políticas públicas do Distrito Federal na plataforma Facebook com o auxílio de ferramentas de análise de mídias digitais e informações fornecidas por participantes e gestores das páginas.

A sua participação ocorrerá pela concessão de entrevista que será gravada e cujas informações serão tornadas públicas no contexto deste estudo. Informamos que você pode se recusar a responder qualquer questão que lhe traga constrangimento, podendo desistir em qualquer momento, sem nenhum prejuízo para você. Sua participação é voluntária, isto é, não há pagamento por sua colaboração.

O Programa de Pós-Graduação em Desenvolvimento, Sociedade e Cooperação Internacional - PPGDSCI é vinculado ao Centro de Estudos Avançados Multidisciplinares - CEAM da Universidade de Brasília e sua Secretaria está localizada no ICC Central, Bloco B, Mezanino, Salas 357/308, Campus Universitário Darcy Ribeiro, Asa Norte, Brasília-DF - CEP 70910-900, podendo ser contatado pelos telefones (61) 3107-6745/ 3107-6744 ou pelo e-mail ppgdsc@unb.br.

Brasília-DF,_ de ___ de __.

Assinatura/ nome do entrevistado:

Assinatura/ nome da pesquisadora: 


\section{APÊNDICE B - Roteiro de entrevista semiestruturada aplicada a ator da sociedade civil (Administrador de fanpage)}

1. Apresentação do entrevistado: nome, idade, escolaridade, formação profissional e local de moradia.

2. Como é a sua relação com a área cultural (trabalhador da área, apoiador, consumidor da indústria criativa)?

3. Quando e como surgiu a ideia da fanpage?

4. Participa de alguma rede presencial de discussão de políticas culturais? Se sim, há influência de uma esfera de discussão sobre a outra?

5. Algum ente estatal já entrou em contato pela fanpage, respondeu algum comentário ou participou de alguma discussão? Se sim, com que frequência isso ocorre? Tem notícia de algum retorno efetivo em ação do poder público?

6. Você já entrou em contato com o poder público presencialmente parra discutir ou acompanhar políticas culturais? Por quê?

7. É mais comum que discuta ou participe de questões relativas a políticas culturais presencialmente ou pela internet? Por quê?

8. Você costuma acompanhar páginas oficiais de algum órgão público na internet para acompanhar ou discutir políticas culturais? Se sim, como avalia essa relação? (os canais são acessíveis? Quais os pontos mais fortes e mais fracos?)

9. Como você escolhe as páginas que vai seguir na internet? Prefere seguir as que tem mais afinidade de pensamento ou segue também para monitorar discussões e debater com outras pessoas?

10. Você acredita que a internet é um espaço interessante para a participação política? Por quê? 


\section{APÊNDICE C - Roteiro de entrevista semiestruturada aplicada a ator da sociedade civil (Membro/seguidor de fanpage)}

1. Apresentação do entrevistado: nome, idade, escolaridade, formação profissional e local de moradia.

2. Como é a sua relação com a área cultural (trabalhador da área, apoiador, consumidor da indústria criativa)?

3. Participa de alguma rede presencial de discussão de políticas culturais? Se sim, há influência de uma esfera de discussão sobre a outra?

4. Participa de outras fanpages de discussão de políticas culturais? Pode citar algumas?

5. Você já esteve em contato com algum ente estatal pelas fanpages ou outro espaço digital, teve algum retorno por essas mídias ou participou de alguma discussão na internet que teve a participação de algum ente estatal? Se sim, com que frequência isso ocorre? Pode comentar sobre essa(s) experiência(s)?

6. Você já entrou em contato com o poder público presencialmente parra discutir ou acompanhar políticas culturais?

7. É mais comum que discuta ou participe de questões relativas a políticas culturais presencialmente ou pela internet? Por quê?

8. Você costuma acompanhar páginas oficiais de algum órgão público na internet para acompanhar ou discutir políticas culturais? Se sim, como avalia essa relação? (Os canais são acessíveis? Quais os pontos mais fortes e mais fracos?)

9. Como você escolhe as páginas que vai seguir na internet? Prefere seguir as que tem mais afinidade de pensamento ou segue também para monitorar discussões e debater com outras pessoas?

10. Você acredita que a internet é um espaço interessante para a participação política? Por quê? 


\section{APÊNDICE D - Roteiro de entrevista semiestruturada aplicada a ente estatal (Administrador de fanpage)}

1. Apresentação do entrevistado e de seu trabalho no poder público: nome, cargo, setor e órgão e há quanto tempo administra a fanpage;

2. Em que contexto foi criada a fanpage?

3. Qual a periodicidade de atualização e como são produzidas as publicações?

4. Há interação com as pessoas que acompanham a página? Como ocorre?

5. As informações tornadas públicas e/ou os debates que acontecem na fanpage são repassados a outros setores do órgão onde trabalha? Como é essa articulação?

6. Como são escolhidas as páginas que a fanpage pretende seguir? É mais comum que siga as que tem mais afinidade ou segue também para monitorar discussões e debater com outras pessoas/grupos/órgãos?

7. Você avalia que há interesse do órgão onde trabalha em investir no diálogo com atores da sociedade civil pela internet? Por quê?

8. Além da fanpage, que outros canais o órgão costuma utilizar para dialogar com atores da sociedade civil? Como tem sido a adesão?

9. Que pontos elencaria como fortes e fracos da fanpage hoje?

10. Você acredita que a internet é um espaço interessante para a participação política? Por quê? 


\section{APÊNDICE E - Roteiro de entrevista semiestruturada aplicada a ente estatal (Autoridade/gestor público)}

1. Apresentação do entrevistado e de seu trabalho no poder público: nome, cargo, setor e órgão;

2. Você avalia que há interesse do órgão onde trabalha em investir no diálogo com atores da sociedade civil pela internet? Por quê?

3. Que pontos elencaria como fortes e fracos da comunicação do órgão onde trabalha com atores da sociedade civil hoje (presencialmente e pela internet)?

4. Além dos canais oficiais da instituição, como gestor você costuma interagir com os cidadãos em canais não oficiais na internet, como um perfil pessoal? O que utiliza mais e por quê?

5. As propostas, críticas e discussões levantadas nos canais de comunicação online do órgão onde trabalha são consideradas no momento da decisão? De que forma?

6. Há projetos futuros e/ou em andamento para fomento à participação social pela internet?

7. Você acredita que a internet é um espaço interessante para a participação política? Por quê?

Com gestor da Secretaria de Cultura, devem ser abordados também os temas Fundo de Apoio à Cultura (FAC) e Plano Distrital de Cultura, tratando de sua articulação e dinâmicas de discussão pela internet e presencialmente. 


\section{APÊNDICE F -Fanpages (759 nós) que integram o grafo da figura 3}

Tabela 6 - Fanpages (759 nós) que integram o grafo da figura 3

(continua)

\begin{tabular}{|c|c|c|c|c|c|c|c|c|c|}
\hline Id & Label & $\ldots \ldots$ & .... & & & & ... Grau de entrada & Grau de saída & Grau \\
\hline $2119543 \ldots$ & Desgoverno do Distrito Federal & $\ldots$ & $\mid . . .$. &.. & $\ldots \mid 1$ & $11 \mid 5$ & $5 \mid 11$ & 221 & 232 \\
\hline $2097169 \ldots$ & Governo de Brasilia & $\ldots$ & $\ldots$ no & 10 . & .... & ... 3 & 370 & 119 & 189 \\
\hline $8433388 \ldots$ & Subsecretaria de Cidadania e Diversidade Cultural & $\ldots$ & $\ldots$. & ... & .... &. .2 & 412 & 156 & 168 \\
\hline $8924026 \ldots$ & Secretaria Adjunta da Mulher Igualdade Racial e Direitos Hu... & $\ldots$ & $\ldots$. & ... & ...... & $\ldots 3$ & 324 & 95 & 119 \\
\hline $4180995 \ldots$ & Na Hora & $\ldots$ & $\ldots$ no & רo. & $\ldots 2$ & 213 & 36 & 90 & 96 \\
\hline $2867257 \ldots$ & Ministério da Cultura & $\ldots$ & $\ldots$ no & רo. & ..... & ... & 443 & 30 & 73 \\
\hline $1688231 \ldots$ & Secretaria Adjunta de Turismo - Brasilia - DF & $\ldots$ & $\ldots$. & ... & ..... & ... 3 & 329 & 37 & 66 \\
\hline $3112608 \ldots$ & Brasilia - DF & $\ldots$ & $\ldots$. & ... & ... 4 & 447 & 76 & 58 & 64 \\
\hline $2712198 \ldots$ & Secretaria de Cultura do Distrito Federal & $\ldots$ & $\ldots$ no & רo. & ..... & $\ldots 3$ & 341 & 19 & 60 \\
\hline $1397748 \ldots$ & Casa Civil do Distrito Federal & $\ldots$ & $\ldots$ no & רo. & $\ldots 6$ & 63 & 314 & 45 & 59 \\
\hline $4671050 \ldots$ & Secretaria de Fazenda do Distrito Federal & $\ldots$ & $\ldots \mathrm{nc}$ & ho. & $\ldots 5$ & 583 & 311 & 39 & 50 \\
\hline $2357182 \ldots$ & Visite Braslia & $\ldots$ & $\ldots .$. & ... & .... & ... 3 & 321 & 28 & 49 \\
\hline $2044102 \ldots$ & Secretaria de Justiça e Cidadania do DF & $\ldots$ & $\ldots$ nc & רo. & $\ldots 2$ & 283 & 321 & 28 & 49 \\
\hline $4219035 \ldots$ & Secretaria da Segurança Pública e da Paz Social do DF & $\ldots$ & $\ldots$ no & רo. & ... & ... 3 & 312 & 36 & 48 \\
\hline $2608890 \ldots$ & DF Hoje & $\ldots$ & $\ldots$ no & רo. & .... & ... 3 & 323 & 24 & 47 \\
\hline $1856404 \ldots$ & TJDFT - Tribunal de Justiça do Distrito Federal e dos Territórios & $\ldots$ & $\ldots$ no & רo. & $\ldots$. & ...2 2 & 27 & 38 & 45 \\
\hline $1598788 \ldots$ & Correio Braziliense & $\ldots$ & $\ldots .$. & ... & $\ldots$. &. .5 & 542 & 2 & 44 \\
\hline $1774741 \ldots$ & Brasilia - Patrimônio Cultural da Humanidade & $\ldots$ & $\ldots$. & ... & $\ldots$. & $\ldots$ & 1039 & 3 & 42 \\
\hline $4594386 \ldots$ & AndaBrasilia & $\ldots$ & $\ldots .$. &.. & $\ldots$. & $\ldots 5$ & 59 & 33 & 42 \\
\hline $1226906 \ldots$ & Superior Tribunal de Justiça (STJ) & $\ldots$ & $\ldots$ no & no. & $\cdots$. & $\ldots 2$ & 219 & 22 & 41 \\
\hline $1903244 \ldots$ & UNESCO na rede & $\cdots$ & $\ldots$ no & no. & ... & $\ldots 2$ & 422 & 14 & 36 \\
\hline $2256641 \ldots$ & CCBB Brasilia & $\ldots$ & $\ldots$ no & no. & $\cdots$. &. .6 & 430 & 5 & 35 \\
\hline $2021384 \ldots$ & Administração Regional de Sobradinho & $\ldots$ & $\ldots .$. &.. & .... &. .3 & 318 & 17 & 35 \\
\hline $4413259 \ldots$ & Secretaria de Saúde do DF & $\ldots$ & $\ldots$ no & רo. & $\ldots$. &. .3 & 325 & 9 & 34 \\
\hline $1266271 \ldots$ & Secretaria de Estado de Políticas para Crianças Adolescente... & $\ldots$ & $\ldots$ nc & רo. & $\ldots$. & $\ldots 3$ & 315 & 18 & 33 \\
\hline $7908259 \ldots$ & Secretaria do Meio Ambiente - SEMA DF & $\ldots$ & $\ldots$ no & רo. & $\ldots$. & ... 3 & 36 & 26 & 32 \\
\hline $1103682 \ldots$ & Polícia Militar do Distrito Federal & $\cdots$ & $\ldots$ nc & רo. & $\ldots$. & .. 3 & 311 & 21 & 32 \\
\hline $4778857 \ldots$ & Anonymous Database & $\ldots$ & $\ldots$. & ... & $\ldots 3$ & 3 & 51 & 31 & 32 \\
\hline $1474883 \ldots$ & O Novo Guia de Brasilia & $\ldots$ & $\ldots$. & ... & $\ldots$. & .. 1 & 1024 & 8 & 32 \\
\hline $2037071 \ldots$ & Tv & $\ldots$ & $\ldots .$. & ... & $\ldots 2$ & 2 & 51 & 30 & 31 \\
\hline $1379997 \ldots$ & Diário de Ceilândia & $\ldots$ & $\ldots .$. & ... . & $\ldots$. & .. 5 & 54 & 27 & 31 \\
\hline $6157301 \ldots$ & Corujinha Foodtruck & $\ldots$ & $\ldots$ no & ho. & $\ldots 8$ & 8 & 1015 & 16 & 31 \\
\hline $1655000 \ldots$ & Direitos Humanos Brasil & $\ldots$ & $\ldots$ nc & רo. & $\cdots$. & .. 3 & 318 & 12 & 30 \\
\hline $5433466 \ldots$ & Burger Truck & $\ldots$ & $\ldots$. & ... & $\ldots$. & $\ldots 1$ & 1017 & 13 & 30 \\
\hline $4324547 \ldots$ & Dona Esponja & $\ldots$ & $\ldots$. & .. $\cdot$ & $\ldots 2$ & 20 & 102 & 28 & 30 \\
\hline $2894117 \ldots$ & SPMulheres & $\mid \ldots$ & $\ldots$ no & nol. & .... & & \begin{tabular}{l|l}
3 & 15
\end{tabular} & 14 & 29 \\
\hline
\end{tabular}


Tabela 6 - Fanpages (759 nós) que integram o grafo da figura 3

(continuação)

\begin{tabular}{|c|c|c|c|c|c|c|c|c|c|c|}
\hline Id & Label & $\ldots .$. & ... & ... & ... & $\cdots$ & $\cdots$ & - Grau de entrada & Grau de saída & Grau \\
\hline $5203165 \ldots$ & Ensaios de viagem & $|\ldots|$ & $|\cdots|$ & $|\cdots|$ & $\cdots$ & ... & $|10|$ & 4 & 25 & 29 \\
\hline $1058723 \ldots$ & Conselho Nacional de Justiça (CNJ) & $\ldots$ & $\ldots r$ & no. & $\ldots$ & $\ldots$ & 2 & 24 & 4 & 28 \\
\hline $2813305 \ldots$ & Picnik no Calçadão & $\ldots$ & $\ldots r$ & no. & $\ldots$ & $\ldots$ & 10 & 26 & 2 & 28 \\
\hline $2172427 \ldots$ & Cidadania e Diversidade & $\ldots$ & $\ldots r$ & no. & $\ldots$ & $\ldots$ & 4 & 11 & 17 & 28 \\
\hline $1991265 \ldots$ & Palácio do Planalto & $\ldots$ & $\ldots r$ & no. & $\ldots$ & $\ldots$ & 3 & 17 & 10 & 27 \\
\hline $1913355 \ldots$ & Ministério do Turismo & $\ldots$ & $\ldots$ & $\ldots$ & $\ldots$ & $\ldots$ & 3 & 17 & 10 & 27 \\
\hline $3479883 \ldots$ & Secretaria de Educação do Distrito Federal & $\ldots$ & $\ldots r$ & no. & $\ldots$ & $\ldots$ & 3 & 16 & 10 & 26 \\
\hline $3445868 \ldots$ & Riacho Citty & $\ldots$ & $\ldots$ & $\ldots$ & $\ldots$ & 40 & 5 & 1 & 25 & 26 \\
\hline $2260538 \ldots$ & Brasilia de graça & $\ldots$ & $\ldots$ & $\ldots$ & $\ldots$ & 42 & 5 & 8 & 18 & 26 \\
\hline $2719175 \ldots$ & Rádio Cultura FM - 1009 & $\ldots$ & $\ldots$ & $\ldots$ & $\ldots$ & $\ldots$ & 15 & 7 & 19 & 26 \\
\hline $4741063 \ldots$ & BSB Criativa & $\ldots$ & $\ldots$ & $\ldots$ & $\ldots$ & 15 & 4 & 5 & 20 & 25 \\
\hline $1657276 \ldots$ & Portal Federativo & $\ldots$ & $\ldots r$ & no. & $\ldots$ & $\ldots$ & 3 & 15 & 9 & 24 \\
\hline $4626656 \ldots$ & Secretaria Adjunta do Trabalho & $\ldots$ & $\ldots$ & $\ldots$ & $\ldots$ & $\ldots$ & 3 & 24 & 0 & 24 \\
\hline $1756511 \ldots$ & Rodrigo Rollemberg & $\ldots$ & $\ldots r$ & no. & $\ldots$ & $\ldots$ & 5 & 11 & 13 & 24 \\
\hline $2633290 \ldots$ & Dia Mundial Sem Carros | DF & $\ldots$ & $\ldots$ & $\ldots$ & $\ldots$ & 28 & 5 & 9 & 15 & 24 \\
\hline $1561542 \ldots$ & Muda Brasilia & $\ldots$ & $\ldots$ & $\ldots$ & $\ldots$ & $\ldots$ & 5 & 4 & 20 & 24 \\
\hline $3034910 \ldots$ & Prefeitura de Brasilia & $\ldots$ & $\ldots$ & $\ldots$ & $\ldots$ & 33 & 10 & 7 & 17 & 24 \\
\hline $2481268 \ldots$ & BSB Memo & $\ldots$ & $\cdots$ & $\ldots$ & $\ldots$ & $\ldots$ & 10 & 14 & 10 & 24 \\
\hline $2944676 \ldots$ & Histórias de Brasilia & $\ldots$ & $\ldots$ & $\ldots$ & $\ldots$ & $\ldots$ & 10 & 14 & 10 & 24 \\
\hline $3247169 \ldots$ & Secretaria de Governo & ... & $|\cdots|$ & $\ldots$ & $\ldots$ & $\ldots$ & 4 & 11 & 13 & 24 \\
\hline $5123665 \ldots$ & Administração Regional do Plano Piloto & $\ldots$ & $\cdots$ & ... & $\ldots$ & 81 & 3 & 10 & 11 & 21 \\
\hline $2961358 \ldots$ & Ministério do Desenvolvimento Social e Combate à Fome & $\ldots$ & $\ldots$ & $\ldots$ & $\ldots$ & $\ldots$ & 3 & 14 & 7 & 21 \\
\hline $6305313 \ldots$ & Luiz Pitiman & $\ldots$ & $\ldots$ & $\ldots$ & $\ldots$ & 36 & 5 & 4 & 17 & 21 \\
\hline $2601391 \ldots$ & Ribs on the truck & $\ldots$ & $\ldots r$ & no. & $\ldots$ & 35 & 10 & 11 & 10 & 21 \\
\hline $1494673 \ldots$ & EmQuadra & $\ldots$ & $\ldots$ & $\ldots$ & $\ldots$ & 2 & 10 & 5 & 16 & 21 \\
\hline $1230648 \ldots$ & Tribunal Superior do Trabalho & $\ldots$ & $\ldots r$ & no. & $\ldots$ & $\ldots$ & 2 & 14 & 6 & 20 \\
\hline $2537704 \ldots$ & Festival de Brasilia do Cinema Brasileiro & $\ldots$ & $\ldots r$ & no. & $\ldots$ & 29 & 3 & 15 & 5 & 20 \\
\hline $5501494 \ldots$ & Corina Cervejas Artesanais & $\ldots$ & $\ldots$ & $\ldots$ & $\ldots$ & $\ldots$ & 10 & 14 & 6 & 20 \\
\hline $2156607 \ldots$ & Cobogó Mercado de Objetos & $\ldots$ & $\ldots$ & $\ldots$ & $\cdots$ & $\cdots$ & 10 & 13 & 7 & 20 \\
\hline $1338512 \ldots$ & TV NBR & $\ldots$ & $\ldots$ & $\ldots$ & $\ldots$ & $\ldots$ & 4 & 12 & 8 & 20 \\
\hline $4644136 \ldots$ & Tribunal de Justiça Maranhão & $\ldots$ & $\cdots$ & $\ldots$ & $\ldots$ & $\ldots$ & 2 & 4 & 15 & 19 \\
\hline $1884090 \ldots$ & Jornal de Brasilia & $\ldots$ & $\ldots r$ & no. & $\ldots$ & $\ldots$ & 5 & 19 & 0 & 19 \\
\hline $3999953 \ldots$ & Secretaria do Território e Habitação do DF & $\ldots$ & $\ldots$ & $\ldots$ & $\ldots$ & 31 & 3 & 14 & 5 & 19 \\
\hline $4071412 \ldots$ & Minha Brasilia & $\ldots$ & $\ldots$ & $\ldots$. & $\ldots$ & $\ldots$ & 10 & 17 & 2 & 19 \\
\hline $1042112 \ldots$ & Sucopira & $\ldots$ & $\cdots$ & $\ldots$ & $\ldots$ & 41 & 10 & 9 & 10 & 19 \\
\hline $1854542 \ldots$ & Ministério Do Desenvolvimento Aarário & $\ldots$ & $\ldots$ & $\ldots$ & $\ldots$ & $\ldots$ & 4 & 8 & 11 & 19 \\
\hline
\end{tabular}


Tabela 6 - Fanpages (759 nós) que integram o grafo da figura 3

(continuação)

\begin{tabular}{|c|c|c|c|c|c|c|c|c|c|c|}
\hline Id & Label & ..... & .... & $\cdots$ & $\cdots$ & ... & & - Grau de entrada & Grau de saída & Grau \\
\hline $2317562 \ldots$ & Tribunal Regional Eleitoral do Distrito Federal & ... & $\mid .$. & ... & $\cdots$ & $\left.47\right|^{2}$ & & 15 & 3 & 18 \\
\hline $2075363 \ldots$ & Arte Rua DF & $\ldots$ & $\ldots$ & $\ldots$ & $\ldots$ & 178 & & 3 & 15 & 18 \\
\hline $3404775 \ldots$ & Assessoria Internacional do GDF & $\ldots$ & $\ldots$ & no & $\ldots$ & 193 & & 4 & 14 & 18 \\
\hline $1394877 \ldots$ & SEDS - Secretaria Adjunta de Desenvolvimento Social & $\ldots$ & $\ldots$ & no. & $\ldots$ & 823 & 3 & 16 & 2 & 18 \\
\hline $2489818 \ldots$ & INCRA OFICIAL - Instituto Nacional de Colonização e Refor... & $\ldots$ & $\ldots$ & no. & $\ldots$ & $\ldots 3$ & 3 & 3 & 15 & 18 \\
\hline $2203948 \ldots$ & Associação dos Magistrados Brasileiros (AMB) & $\ldots$ & $\ldots$ & no. & $\ldots$ & $\ldots 2$ & 2 & 1 & 16 & 17 \\
\hline $2543293 \ldots$ & Movimento Contra Corrupção & $\ldots$ & $\ldots$ & no & $\ldots$ & $\ldots 5$ & 5 & 14 & 3 & 17 \\
\hline $2330548 \ldots$ & Cine Brasilia & $\ldots$ & $\ldots$ & $\ldots$ & $\ldots$ & $\ldots 3$ & 3 & 9 & 8 & 17 \\
\hline $4298028 \ldots$ & Defensoria Pública do DF & $\ldots$ & $\ldots$ & no & $\ldots$ & $\ldots 3$ & 3 & 11 & 6 & 17 \\
\hline $2727202 \ldots$ & Instituto Brasileiro de Museus - Ibram & $\ldots$ & $\ldots$ & no & $\ldots$ & $\ldots 3$ & 3 & 6 & 11 & 17 \\
\hline $4065459 \ldots$ & Quadrado Brasilia & $\ldots$ & $\ldots$ & $\ldots$ & $\ldots$ & 52 & 10 & 17 & 0 & 17 \\
\hline $3320153 \ldots$ & Latinidades Afrolatinas & $\ldots$ & $\ldots$ & $\ldots$ & $\ldots$ & 80 & 4 & 10 & 7 & 17 \\
\hline $3413015 \ldots$ & Núcleo de Enfrentamento à Violência contra a Pessoa Idosa & $\ldots$ & $\ldots$ & $\ldots$ & $\ldots$ & 17 & & 2 & 15 & 17 \\
\hline $1331042 \ldots$ & Ministério do Trabalho e Previdência Social & $\ldots$ & $\ldots$ & no. & $\ldots$ & $\ldots$ & 4 & 10 & 7 & 17 \\
\hline $1888133 \ldots$ & Conselho Nacional do Ministério Público & $\ldots$ & $\ldots$ & $\ldots$ & $\ldots$ & $\ldots 2$ & 2 & 11 & 5 & 16 \\
\hline $1131073 \ldots$ & Administração Regional de Águas Claras & $\ldots$ & $\ldots$ & no. & $\ldots$ & $\ldots 3$ & 3 & 16 & 0 & 16 \\
\hline $3329346 \ldots$ & AnonymousBrasil & $\ldots$ & $\ldots$ & $\ldots$ & $\ldots$ & $\ldots 5$ & 5 & 15 & 1 & 16 \\
\hline $1649512 \ldots$ & BRASILIA S/A & $\ldots$ & $\ldots$ & $\ldots$ & $\ldots$ & 0 & & 5 & 11 & 16 \\
\hline $3461891 \ldots$ & Bistrucknarua & $\ldots$ & $\ldots$ & .... & $\ldots$ & 6 & 10 & 15 & 1 & 16 \\
\hline $3315202 \ldots$ & Espaço Cultural Mercado Sul & ... & ... & $|\cdots|$ & ... & $|\ldots|$ & 4 & 6 & 10 & 16 \\
\hline $2041060 \ldots$ & PNUD Brasil & $\ldots$ & $\ldots$ & no. & $\ldots$ & $\ldots 3$ & 3 & 10 & 4 & 14 \\
\hline $2025898 \ldots$ & Secretaria de Ciência Tecnologia e Inovação - Secti DF & $\ldots$ & $\ldots$ & $\ldots$ & $\ldots$ & 73 & 3 & 10 & 4 & 14 \\
\hline $1209341 \ldots$ & Corpo de Bombeiros Militar do DF & $\ldots$ & $\ldots$ & no. & $\ldots$ & $\ldots 3$ & 3 & 14 & 0 & 14 \\
\hline $3408870 \ldots$ & Acorda Brasilia & $\ldots$ & $\ldots$ & $\ldots$ & $\ldots$ & 35 & 5 & 2 & 12 & 14 \\
\hline $1665379 \ldots$ & Em Brasilia & $\ldots$ & $\ldots$ & $\ldots$ & $\ldots$ & $\ldots 5$ & 5 & 9 & 5 & 14 \\
\hline $1589736 \ldots$ & Naked Barbecue DF & $\ldots$ & $\ldots$ & $\ldots$ & $\ldots$ & $\ldots 1$ & 10 & 7 & 7 & 14 \\
\hline $3684162 \ldots$ & Bistrô Itinerante & $\ldots$ & $\ldots$ & $\ldots$ & $\ldots$ & 4 & & 3 & 11 & 14 \\
\hline $1445725 \ldots$ & Camelo Bike Tour & $\ldots$ & $\ldots$ & $\ldots$ & $\ldots$ & $\ldots 1$ & 10 & 5 & 9 & 14 \\
\hline $2622157 \ldots$ & Cine Drive-in Brasilia & $\ldots$ & $\ldots$ & no. & $\ldots$ & $\ldots 1$ & 10 & 10 & 4 & 14 \\
\hline $1422967 \ldots$ & Batuqueiras & $\ldots$ & $\ldots$ & $\ldots$ & $\ldots$ & $\ldots{ }^{2}$ & & 3 & 11 & 14 \\
\hline $2626997 \ldots$ & Ministério da Justiça & $\ldots$ & $\ldots$ & no. & $\ldots$ & $\ldots 4$ & 4 & 11 & 3 & 14 \\
\hline $1530453 \ldots$ & ICDF - Instituto de Cardiologia do Distrito Federal & $\ldots$ & $\ldots$ & no. & $\ldots$ & $\ldots 3$ & 3 & 1 & 12 & 13 \\
\hline $4240647 \ldots$ & Administração Regional do Gama & $\ldots$ & $\ldots$ & $\ldots$ & $\ldots$ & 613 & & 10 & 3 & 13 \\
\hline $5752257 \ldots$ & Posso ajudar Brasilia? & $\ldots$ & $\ldots$ & $\ldots$ & $\ldots$ & 05 & 5 & 2 & 11 & 13 \\
\hline $6190114 \ldots$ & Muda Brasil & $\ldots$ & $\ldots$ & ... & $\ldots$ & 105 & & 1 & 12 & 13 \\
\hline $1885747 \ldots$ & Manifestacão De 7 Setembro 2013 & $\ldots$ & $\ldots$ & no. & $\ldots$ & 175 & & 2 & 11 & 13 \\
\hline
\end{tabular}


Tabela 6 - Fanpages (759 nós) que integram o grafo da figura 3

(continuação)

\begin{tabular}{|c|c|c|c|c|c|c|c|c|c|}
\hline Id & Label & $\ldots \ldots$ & $\ldots$ & & $\ldots$. & $\cdots$. & ... Grau de entrada & Grau de saída & Grau \\
\hline $3617295 \ldots$ & Sou Brasilia & $|\cdots|$ & $\ldots n$ & no. & ..... & ... 5 & $5 \mid 2$ & 11 & 13 \\
\hline $1375767 \ldots$ & Vinny s Pizza Foodtruck & $\ldots$ & $\ldots$. & $\ldots$. & ...... & ... 1 & 106 & 7 & 13 \\
\hline $2470746 \ldots$ & IAB DF & $\ldots$ & $\ldots$. & $\ldots$. & $\ldots 1$ & 181 & 106 & 7 & 13 \\
\hline $4862047 \ldots$ & Coordenação dos Núcleos de Direitos Humanos - MPDFT & $\ldots$ & $\ldots$. & $\ldots$. & ... 3 & 354 & 42 & 11 & 13 \\
\hline $3842414 \ldots$ & Coletivo Expressão & $\ldots$ & $\ldots$. & $\ldots$. & $\ldots 1$ & 154 & 47 & 6 & 13 \\
\hline $1190137 \ldots$ & Tribunal de Justiça do Estado do Acre & $\ldots$ & $\ldots n$ & no. & ..... & .. 2 & 23 & 9 & 12 \\
\hline $1806945 \ldots$ & Record Brasilia & $\ldots$ & $\ldots$. & $\ldots$. & ..... & .. 5 & 510 & 2 & 12 \\
\hline $1861886 \ldots$ & Manifestação Brasilia & $\ldots$ & $\ldots$. & $\ldots$. & ..... & ... 5 & 55 & 7 & 12 \\
\hline $1195294 \ldots$ & Associação dos moradores de Ceilândia & $\ldots$ & $\ldots n$ & no. & $\ldots 0$ & 3 & 39 & 3 & 12 \\
\hline $1048018 \ldots$ & Instituto Federal Brasilia - IFB & $\ldots$ & $\ldots$. & $\ldots$. & ...... & ... 3 & 38 & 4 & 12 \\
\hline $7299394 \ldots$ & Best Quotes Ever & $\ldots$ & $\ldots$. & $\ldots$. & ...... & ... 5 & 12 & 0 & 12 \\
\hline $2128464 \ldots$ & Face Bike Pedal e Ciclismo & $\ldots$ & $\ldots$. & $\ldots$. & ...... & ... 5 & 54 & 8 & 12 \\
\hline $1539859 \ldots$ & AnonymousBR & $\ldots$ & $\ldots$. & $\ldots$. & ..... & .. 5 & 58 & 4 & 12 \\
\hline $2565188 \ldots$ & Basta Corrupção & $\ldots$ & $\ldots$. & $\ldots$. & $\ldots 6$ & 525 & 57 & 5 & 12 \\
\hline $1641882 \ldots$ & NINJA & $\ldots$ & $\ldots$. & $\ldots$. & $\ldots .$. & ... 5 & 56 & 6 & 12 \\
\hline $7778459 \ldots$ & Malibu Food Truck & $\ldots$ & $\ldots$. & $\ldots$. & ... 9 & 991 & 104 & 8 & 12 \\
\hline $3166914 \ldots$ & Komboleria & $\ldots$ & $\ldots n$ & no. & ..... & ... 1 & 109 & 3 & 12 \\
\hline $3529566 \ldots$ & Chefs nos Eixos & $\ldots$ & $\ldots n$ & no. & $\ldots 4$ & 401 & 106 & 6 & 12 \\
\hline $2000838 \ldots$ & Catraca Livre Brasilia & $\ldots$ & $\ldots$ & $\ldots$. & $\ldots .$. & 1 & 108 & 4 & 12 \\
\hline $3618358 \ldots$ & Waze Brasilia & |.. & $\ldots \mid$. & .... & $\ldots 0$ & & $10 \mid 1$ & 11 & 12 \\
\hline $5384811 \ldots$ & Procon-DF & $\ldots$ & $\ldots n$ & no. & $\ldots 3$ & 313 & 310 & 1 & 11 \\
\hline $5402979 \ldots$ & Brasil Contra Corrupção & $\ldots$ & $\ldots$. & .... & ...... & ... 5 & 10 & 1 & 11 \\
\hline $2599708 \ldots$ & MPL-DF & $\ldots$ & $\ldots$. & .... & ..... & ... 5 & 56 & 5 & 11 \\
\hline $6323010 \ldots$ & Amazing Cars & $\ldots$ & $\ldots$. & $\ldots$. & ... 8 & 35 & 511 & 0 & 11 \\
\hline $2341188 \ldots$ & Gags and laughs & $\ldots$ & $\ldots$. & $\ldots$. & $\ldots 1$ & 165 & 511 & 0 & 11 \\
\hline $2239757 \ldots$ & Funny Quotes & $\ldots$ & $\ldots$. & $\ldots$. & \begin{tabular}{l|l}
$\ldots$ &..
\end{tabular} & .. 5 & \begin{tabular}{|l|l}
5 & 11
\end{tabular} & 0 & 11 \\
\hline $2551538 \ldots$ & Veja Brasilia & $\ldots$ & $\ldots n$ & no. & $\ldots .$. & 5 & \begin{tabular}{|l|l}
5 & 11
\end{tabular} & 0 & 11 \\
\hline $6292208 \ldots$ & Brasilia Alternativa & $\ldots$ & $\ldots n$ & no. & ... 5 & $\begin{array}{ll}571 & 1\end{array}$ & 1011 & 0 & 11 \\
\hline $2495209 \ldots$ & Consumo Social & $\ldots$ & $\ldots$. & $\ldots$. & $\ldots 1$ & 17 & 75 & 6 & 11 \\
\hline $1274811 \ldots$ & Catarse & $\ldots$ & $\ldots$. & $\ldots$. & \begin{tabular}{l|l} 
& $\ldots$.
\end{tabular} & $\ldots 1$ & 105 & 6 & 11 \\
\hline $1002730 \ldots$ & Ministério Público do Estado da Bahia & $\ldots$ & $\ldots n$ & no. & ...... & ... 2 & 25 & 6 & 11 \\
\hline $1503115 \ldots$ & Senado Federal & $\ldots$ & $\ldots n$ & no. & ..... & ... 4 & 411 & 0 & 11 \\
\hline $1629238 \ldots$ & Tribunal de Justiça do Estado do Amazonas & $\ldots$ & $\ldots n$ & no. & ..... & $\ldots 2$ & 25 & 5 & 10 \\
\hline $4797383 \ldots$ & SBT Braslia & $\ldots$ & $\ldots$. & $\ldots$. & ..... & ... 5 & 59 & 1 & 10 \\
\hline $2774448 \ldots$ & Administração Regional do Lago Norte & $\ldots$ & $\ldots$. & $\ldots$. & ..... & ... 3 & 310 & 0 & 10 \\
\hline $3351586 \ldots$ & Fecomércio DF & $\ldots$ & $\ldots \mathrm{n}$ & no. & ..... & .3 & 35 & 5 & 10 \\
\hline
\end{tabular}


Tabela 6 - Fanpages (759 nós) que integram o grafo da figura 3

(continuação)

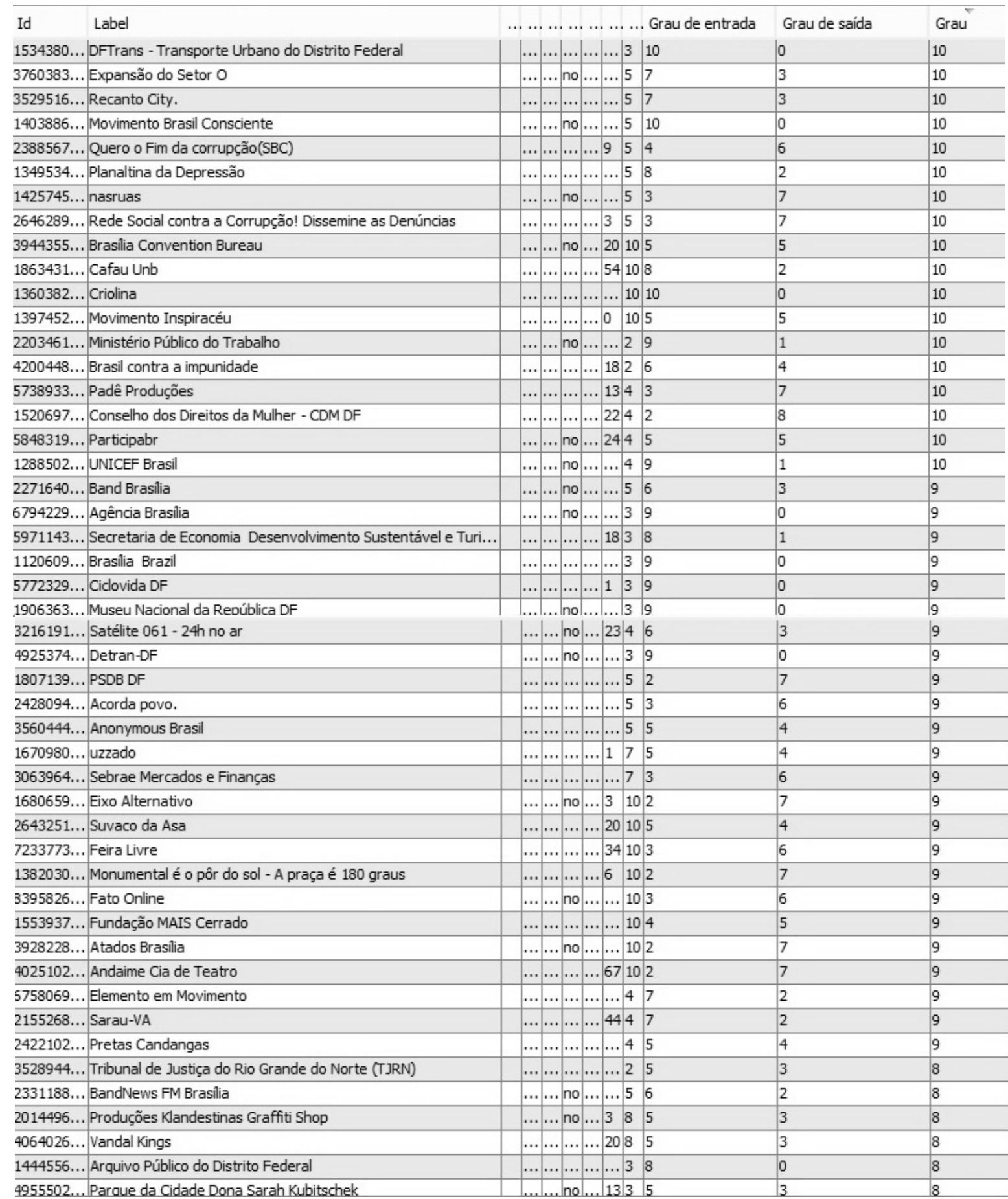


Tabela 6 - Fanpages (759 nós) que integram o grafo da figura 3

(continuação)

\begin{tabular}{|c|c|c|c|c|c|c|c|c|c|c|}
\hline Id & Label & $\ldots \ldots$ & .... & $\cdots$ & $\cdots$ & $\cdots$ & & Grau de entrada & Grau de saida & Grau \\
\hline $1180263 \ldots$ & Jardim Botânico de Brasilia - JBB & $\ldots$ & $\ldots$ & $\ldots$ & $\ldots$. & $\ldots 3$ & & 7 & 1 & 8 \\
\hline $3296760 \ldots$ & Agência Nacional de Águas - ANA & $\ldots$ & $\ldots r$ & no & ... & $\ldots 3$ & & 5 & 3 & 8 \\
\hline $3096920 \ldots$ & Fundação Hemocentro de Brasilia & $\ldots$ & $\ldots$ & $\cdots$ & $\ldots$. & $\ldots 3$ & & 6 & 2 & 8 \\
\hline $1844402 \ldots$ & Brasilia & $\ldots$ & $\ldots$ & $\ldots$ & $\ldots 2^{2}$ & 413 & & 8 & 0 & 8 \\
\hline $1699833 \ldots$ & TV Revolta & $\ldots$ & $\ldots$ & $\cdots$ & $\ldots$. & $\ldots 5$ & & 4 & 4 & 8 \\
\hline $1334982 \ldots$ & DeBoa Brasilia & $\cdots$ & $\ldots r$ & no & $\ldots$. & $\ldots 5$ & 5 & 7 & 1 & 8 \\
\hline $1668603 \ldots$ & Cristovam Buarque & $\ldots$ & $\ldots r$ & no & ... & $\ldots 5$ & & 4 & 4 & 8 \\
\hline $1698431 \ldots$ & Juventude Contra Corrupção & $\ldots$ & $\ldots$ & $\ldots$ & $\ldots$. & $\ldots 5$ & 5 & 7 & 1 & 8 \\
\hline $3875871 \ldots$ & UnB Places & $\ldots$ & $\cdots$ & $\cdots$ & ... & $\ldots$. & & 2 & 6 & 8 \\
\hline $7032489 \ldots$ & Hamburgueria do Cheff - Food Truck & $\ldots$ & $\cdots$ & $\cdots$ & $\ldots 9$ & 92 & & 7 & 1 & 8 \\
\hline $1444334 \ldots$ & Kombinni Coffeetruck & $\ldots$ & $\cdots$ & $\cdots$ & $\ldots 1$ & 14. & 10 & 8 & 0 & 8 \\
\hline $3777984 \ldots$ & IphanGovBr & $\ldots$ & $\ldots r$ & no & ... & $\ldots 1$ & & 8 & 0 & 8 \\
\hline $4403807 \ldots$ & Escola Superior do Ministério Público da União & $\ldots$ & $\ldots r$ & no & $\ldots 3$ & 302 & & 2 & 6 & 8 \\
\hline $4521288 \ldots$ & Ouvidoria do Ministério Público do Distrito Federal e Territórios & $\ldots$ & $\ldots$ & $\ldots$ & $\ldots 6$ & 692 & & 3 & 5 & 8 \\
\hline $1033309 \ldots$ & Conselho Nacional de Procuradores Gerais - CNPG & $\ldots$ & $\ldots r$ & no & $\ldots 6$ & 62 & & 3 & 5 & 8 \\
\hline $1650463 \ldots$ & Coletivo Pé de Ipê & $\ldots$ & ... & $\cdots$ & $\ldots$ & $\ldots$ & & 1 & 7 & 8 \\
\hline $5422656 \ldots$ & ONU Mulheres Brasil & $\ldots$ & $\ldots i r$ & no & $\ldots$ & $\ldots k$ & & 6 & 2 & 8 \\
\hline $1426602 \ldots$ & Movimento Contra Corrupção - Distrito Federal & $\ldots$ & ... & ... & $\ldots 5$ & 505 & & 6 & 1 & 7 \\
\hline $2925149 \ldots$ & Combata a Dengue & $\cdots$ & $\ldots r$ & no. & ... & ... 3 & & 6 & 1 & 7 \\
\hline $2437399 \ldots$ & Agnelo da Depressão & $\ldots$ & ... & ... & $\ldots 0$ & 5 & & 2 & 5 & 7 \\
\hline $2864847 \ldots$ & Conselho de Arquitetura e Urbanismo do Brasil - Cau/BR & $\ldots$ & $\ldots r$ & no. & ... & ... 1 & & 5 & 2 & 7 \\
\hline $1647871 \ldots$ & DF Alerta (oficial) & $\ldots$ & $\ldots$ & ... & .... & ... 5 & & 6 & 1 & 7 \\
\hline $2084357 \ldots$ & Povo Brasileiro & $\ldots$ & $\ldots$ & ... & ... & ... 5 & & 7 & 0 & 7 \\
\hline $1805628 \ldots$ & G1 - O Portal de Notícias da Globo & $\ldots$ & $\ldots r$ & no. & ... & ... 5 & & 7 & 0 & 7 \\
\hline $5680255 \ldots$ & Jornal Local - Tv Brasilia & $\ldots$ & $\ldots$. & ... & ... & ... 5 & & 7 & 0 & 7 \\
\hline $4390882 \ldots$ & Radar Santa Maria-DF & $\ldots$ & $\ldots$. & ... & ... & ... 5 & & 7 & 0 & 7 \\
\hline $1401407 \ldots$ & FORA PT & $\ldots$ & $\ldots r$ & no. & ... & ... 5 & & 6 & 1 & 7 \\
\hline $1971928 \ldots$ & Anonymous & $\ldots$ & $\ldots r$ & no. & ... & ... 5 & & 7 & 0 & 7 \\
\hline $1740120 \ldots$ & Comite Popular da Copa - DF & $\ldots$ & ... & ... & $\ldots 4$ & 45 & & 4 & 3 & 7 \\
\hline $3067571 \ldots$ & Mala do Livro DF & $\ldots$ & $\ldots$. & $\ldots$. & $\ldots 1$ & 121 & & 3 & 4 & 7 \\
\hline $4972463 \ldots$ & Hipster da Capital & $\cdots$ & $\ldots$. & ... & ... & ... 1 & & 5 & 2 & 7 \\
\hline $2252033 \ldots$ & Olhe os muros & $\ldots$ & $\ldots r$ & no. & … & ... 8 & & 4 & 3 & 7 \\
\hline $5467418 \ldots$ & Olhares Sobre Brasilia & $\ldots$ & $\ldots r$ & no. & $\ldots 2$ & 211 & & 1 & 6 & 7 \\
\hline $7529822 \ldots$ & Proieto Reacão & $\ldots$ & $\ldots$ & & $\ldots$ & 191 & & 7 & 0 & 7 \\
\hline
\end{tabular}


Tabela 6 - Fanpages (759 nós) que integram o grafo da figura 3

(continuação)

\begin{tabular}{|c|c|c|c|c|c|c|c|c|c|c|}
\hline Id & Label & $\ldots .$. & .... & $\ldots$ & $\ldots$ & $\cdots$ & & - Grau de entrada & Grau de saída & Grau \\
\hline $7348771 \ldots$ & Agricultura Urbana Brasilia & $\ldots$ & $|\ldots|$ & $\ldots$ & $\ldots$ & $|18|$ & & 3 & 4 & 7 \\
\hline $1418881 \ldots$ & Céu com Cinema & $\ldots$ & $\ldots$ & $\cdots$ & $\ldots$ & 10 & 10 & 7 & 0 & 7 \\
\hline $1629025 \ldots$ & Casa da Cultura da América Latina da UnB & $\ldots$ & $\ldots$ & $\ldots$ & $\ldots$ & $\ldots 2^{2}$ & & 4 & 3 & 7 \\
\hline $5146051 \ldots$ & Correria Em Ceilândia & $\ldots$ & $\ldots$ & $\ldots$ & $\ldots$ & 14 & & 1 & 6 & 7 \\
\hline $2227937 \ldots$ & Aborígine Rap & $\ldots$ & $\ldots$ & $\cdots$ & $\ldots$ & 72 & & 2 & 5 & 7 \\
\hline $2690956 \ldots$ & Tribunal de Justiça do Ceará (Oficial) & $\ldots$ & $\ldots$ & no. & $\ldots$ & $\ldots 2$ & & 5 & 1 & 6 \\
\hline $2239339 \ldots$ & Tribunal de Justiça de São Paulo & $\ldots$ & $\ldots$ & no. & $\ldots$ & $\ldots 2$ & & 6 & 0 & 6 \\
\hline $2157442 \ldots$ & Tribunal de Justiça do Estado do Amapá & $\ldots$ & $\ldots$ & no. & $\ldots$ & $\ldots 2$ & & 4 & 2 & 6 \\
\hline $2117525 \ldots$ & Tribunal de Justiça do Estado de Alagoas & $\ldots$ & $\ldots$ & no. & $\ldots$ & $\ldots 2$ & 2 & 6 & 0 & 6 \\
\hline $1875787 \ldots$ & UnB - Universidade de Brasilia & $\ldots$ & $\ldots$ & no. & $\ldots$ & $\ldots 3$ & & 6 & 0 & 6 \\
\hline $2355077 \ldots$ & Cena Contemporânea & $\ldots$ & $\ldots$ & $\ldots$ & $\ldots$ & 403 & & 4 & 2 & 6 \\
\hline $3132338 \ldots$ & Comunicadf & $\ldots$ & ... & $\cdots$ & $\cdots$ & 13 & 3 & 5 & 1 & 6 \\
\hline $1610391 \ldots$ & REGUFFE - Oficial. & $\ldots$ & $\ldots$ & no. & $\ldots$ & $\ldots 5$ & & 6 & 0 & 6 \\
\hline $4211419 \ldots$ & DF em Debate & $\ldots$ & $\ldots$ & no. & $\ldots$ & 25 & 5 & 3 & 3 & 6 \\
\hline $6171212 \ldots$ & Mídia Informal & $\ldots$ & $\ldots$ & $\cdots$ & $\ldots$ & $\ldots 5$ & 5 & 6 & 0 & 6 \\
\hline $1620979 \ldots$ & CQC na Band & $\ldots$ & $\ldots$ & no. & $\ldots$ & $\ldots 5$ & & 6 & 0 & 6 \\
\hline $1516970 \ldots$ & Dia do Basta & $\ldots$ & $\ldots$ & $\ldots$ & $\ldots$ & $\ldots 5$ & & 6 & 0 & 6 \\
\hline $2546330 \ldots$ & Muda Brasil & $\ldots$ & $\ldots$ & $\ldots$ & $\ldots$ & 715 & & 5 & 1 & 6 \\
\hline $2612278 \ldots$ & Band Cidade DF & $\ldots$ & $\ldots$ & no. & $\ldots$ & 115 & 5 & 3 & 3 & 6 \\
\hline $1943524 \ldots$ & Movimento Brasil Contra Corrupção & $\ldots$ & $\ldots$ & $\ldots$ & $\ldots$ & $\ldots 5$ & 5 & 6 & 0 & 6 \\
\hline $4630964 \ldots$ & Pastéis da Tia Neuza & $\ldots$ & $\ldots$ & $\ldots$ & $\ldots$ & 90 & 10 & 6 & 0 & 6 \\
\hline $5605376 \ldots$ & Geléia Food Truck & $\ldots$ & $\ldots$ & $\ldots$ & $\ldots$ & $\ldots$ & & 6 & 0 & 6 \\
\hline $5044238 \ldots$ & Brasiliagenda Brasilia Brasiliagenda & $\ldots$ & $\ldots$ & $\ldots$ & $\ldots$ & 11 & 10 & 6 & 0 & 6 \\
\hline $1006084 \ldots$ & Cidade Democrática & $\ldots$ & $\ldots$ & $\ldots$ & $\ldots$ & $\ldots$ & 10 & 5 & 1 & 6 \\
\hline $4525639 \ldots$ & Verdurão Camisetas & $\ldots$ & $\ldots$ & $\ldots$ & $\ldots$ & $\ldots$ & 10 & 4 & 2 & 6 \\
\hline $2822918 \ldots$ & O que você tem a ver com a corrupção? & $\ldots$ & $\ldots$ & $\ldots$ & $\ldots$ & 532 & & 4 & 2 & 6 \\
\hline $1751723 \ldots$ & Filhos de Dona Maria & $\ldots$ & $\ldots$ & $\ldots$ & $\ldots$ & $\ldots 2^{2}$ & 4 & 3 & 3 & 6 \\
\hline $2168620 \ldots$ & Festival Internacional de Filmes Curtíssimos & $\ldots$ & $\ldots$ & $\ldots$ & $\ldots$ & $\ldots 2$ & 4 & 3 & 3 & 6 \\
\hline $1215396 \ldots$ & Escola de Gente - Comunicação em Inclusão & $\ldots$ & $\ldots$ & no. & $\ldots$ & $\ldots 2^{2}$ & & 2 & 4 & 6 \\
\hline $2839915 \ldots$ & Márcia Paixão & $\ldots$ & $\ldots$ & no. & $\ldots$ & 12 & 4 & 2 & 4 & 6 \\
\hline $1348163 \ldots$ & Coletivo B.Rocker s & $\ldots$ & $\ldots$ & $\ldots$ & $\ldots$ & 62 & & 5 & 1 & 6 \\
\hline $4902207 \ldots$ & Poeta Marina Mara & $\ldots$ & $\ldots$ & $\ldots$ & $\ldots$ & $\ldots 2^{2}$ & & 2 & 4 & 6 \\
\hline $6879349 \ldots$ & UNICEF & $\ldots$ & $\ldots$ & no & $\ldots$ & $\ldots 2$ & & 5 & 1 & 6 \\
\hline $2101822 \ldots$ & Alvaro Henrique & $\ldots$ & $\ldots$ & $\ldots$ & $\ldots$ & $\ldots 3$ & & 2 & 3 & 5 \\
\hline $3951496 \ldots$ & Tribunal de Justiça do Estado do Rio Grande do Sul (TJRS) & $\ldots$ & $\ldots$ & no. & $\ldots$ & $\ldots 2$ & & 5 & 0 & 5 \\
\hline $2732609 \ldots$ & Tribunal de Justica de Mato Grosso do Sul & $\ldots$ & $\ldots$ & no & $\ldots$ & $\ldots 2$ & 2 & 5 & 0 & 5 \\
\hline
\end{tabular}


Tabela 6 - Fanpages (759 nós) que integram o grafo da figura 3

(continuação)

\begin{tabular}{|c|c|c|c|c|c|c|c|c|}
\hline Id & Label & $\ldots \ldots$ & ...... & .... & $\cdots$. & ... Grau de entrada & Grau de saída & Grau \\
\hline $2767293 \ldots$ & Tribunal de Justiça de Minas Gerais & $|\cdots|$ & ... no & $0 \mid . .$. & $\ldots 2$ & $2 \mid 5$ & 0 & 5 \\
\hline $1760246 \ldots$ & TJGO & $\ldots$ & ... no & $0 . .$. & $\ldots 2$ & 24 & 1 & 5 \\
\hline $4132667 \ldots$ & Tribunal Regional do Trabalho da $10^{\mathrm{a}}$ Região & $\ldots$ & ... no & $0 . .$. & $\ldots 2$ & 23 & 2 & 5 \\
\hline $2000685 \ldots$ & Teatro Nacional de Brasilia & $\ldots$ & $\ldots$ no & $0 . . .5$ & 503 & 35 & 0 & 5 \\
\hline $9666883 \ldots$ & Ministério da Saúde - HIV/Aids & $\ldots$ & ... no & $0 . .$. & $\ldots 3$ & 34 & 1 & 5 \\
\hline $3504072 \ldots$ & ConsocialDF & $\ldots$ & $\ldots \ldots$ & .... 0 & $0 \quad 3$ & 34 & 1 & 5 \\
\hline $9256243 \ldots$ & Liliane Roriz & $\ldots$ & ... no & $0 . .$. & $\ldots 5$ & 52 & 3 & 5 \\
\hline $1332613 \ldots$ & Eliana Pedrosa & $\ldots$ & ... no & $0 . . .1$ & 195 & 53 & 2 & 5 \\
\hline $2076743 \ldots$ & Braslia por Chico Sant Anna & $\ldots$ & $\ldots \ldots$ &.$\ldots 7$ & 75 & 54 & 1 & 5 \\
\hline $5450853 \ldots$ & Sobradinho da Depressão & $\ldots$ & $\ldots \ldots$ &.$\ldots 8$ & 895 & \begin{tabular}{l|l}
5 & 1
\end{tabular} & 4 & 5 \\
\hline $2677774 \ldots$ & Bicicleta & $\ldots$ & $\ldots \ldots$ & ...... & $\ldots 5$ & 55 & 0 & 5 \\
\hline $4488282 \ldots$ & Eu amo Brasilia & $\ldots$ & $\ldots \ldots$ & ...... & $\ldots 5$ & 54 & 1 & 5 \\
\hline $3113497 \ldots$ & Aeroporto Internacional de Brasilia & $\ldots$ & ... no & $0 . . .$. & $\ldots 5$ & 52 & 3 & 5 \\
\hline $1507762 \ldots$ & Polícia Civil do Distrito Federal - PCDF & $\ldots$ & ... no & $0 . .$. & $\ldots 5$ & 55 & 0 & 5 \\
\hline $1565934 \ldots$ & Acorda Brasilia & $\ldots$ & $\ldots \ldots$ & $\ldots 1$ & 15 & 52 & 3 & 5 \\
\hline $4057747 \ldots$ & Ocupa Brasil - União Brasilia & $\cdots$ & ... no & $0 . .7$ & 75 & 54 & 1 & 5 \\
\hline $1922550 \ldots$ & Brasilia & $\ldots$ & $\ldots \ldots$ & .... & ... 5 & 55 & 0 & 5 \\
\hline $1046311 \ldots$ & AaendaDF.com.br & $\ldots$ & $\ldots \ldots$ & $\ldots 1$ & 105 & 53 & 2 & 5 \\
\hline $3525923 \ldots$ & No Entorno de Brasilia & $|\ldots|$ & $|\ldots| \ldots$ & $\cdot \ldots \mid$. & $\ldots \mid 5$ & $5 \mid 4$ & 1 & 5 \\
\hline $1030728 \ldots$ & Brazilian Urban Art & $\cdots$ & $\ldots \ldots$ & ... 0 & $0 \quad 8$ & 82 & 3 & 5 \\
\hline $2078355 \ldots$ & Os Gemeos & $\ldots$ & ... no & $0 . . .$. & $\ldots 8$ & 85 & 0 & 5 \\
\hline $1541586 \ldots$ & BSB todo dia & $\ldots$ & $\ldots \ldots$ &.$\ldots 0$ & \begin{tabular}{l|l}
0 & 1 \\
\end{tabular} & 101 & 4 & 5 \\
\hline $3684210 \ldots$ & Dozai Urban Food & $\ldots$ & $\ldots \ldots$ & $\ldots 1$ & 141 & 105 & 0 & 5 \\
\hline $5227301 \ldots$ & Tapiocas da Xica & $\ldots$ & $\ldots \ldots$ & ... 1 & \begin{tabular}{l|l}
1 & 1 \\
\end{tabular} & 105 & 0 & 5 \\
\hline $6756701 \ldots$ & Belgrado Burger & $\cdots$ & $\ldots \ldots$ & .... & $\ldots 1$ & 104 & 1 & 5 \\
\hline $3379948 \ldots$ & Rejunta Meu Bulcão & $\ldots$ & $\ldots \ldots$ & $\ldots 2$ & 241 & 102 & 3 & 5 \\
\hline $2984717 \ldots$ & Babydoll de Nylon & $\ldots$ & $\ldots \ldots$ & .... & \begin{tabular}{|l|l}
$\ldots$ & 1 \\
\end{tabular} & 105 & 0 & 5 \\
\hline $3933410 \ldots$ & Água sua linda & $\ldots$ & $\ldots \ldots$ &.$\ldots$. & $\ldots 1$ & 104 & 1 & 5 \\
\hline $5348144 \ldots$ & 5norte & $\ldots$ & $\ldots \ldots$ &.$\ldots 2$ & 21 & 105 & 0 & 5 \\
\hline $2979189 \ldots$ & Superquadra Criativa & $\ldots$ & $\ldots \ldots$ & ...9 & 9 & 105 & 0 & 5 \\
\hline $4561810 \ldots$ & DF + Árvores & $\ldots$ & $\ldots \ldots$ & ... 0 & 0 & \begin{tabular}{l|l}
10 & 1
\end{tabular} & 4 & 5 \\
\hline $2714781 \ldots$ & Associação do Ministério Público do Distrito Federal e Territó... & $\ldots$ & ... no & $0 . . .3$ & 302 & 21 & 4 & 5 \\
\hline $1008886 \ldots$ & Agenda Cultural Brasilia & $\ldots$ & ... no & $0 \ldots$. & $\ldots 4$ & 43 & 2 & 5 \\
\hline $5044252 \ldots$ & TV Reflexo Digital & $\ldots$ & $\ldots \ldots$ & $\ldots 3$ & 344 & 43 & 2 & 5 \\
\hline $3491829 \ldots$ & TV Comunitária de Brasilia DF & $\ldots$ & ... no & $0 . . .3$ & 304 & 45 & 0 & 5 \\
\hline $1152038 \ldots$ & Cia. Nós No Bambu & لم. & & & & \begin{tabular}{l|l}
4 & 4 \\
\end{tabular} & 1 & 5 \\
\hline
\end{tabular}


Tabela 6 - Fanpages (759 nós) que integram o grafo da figura 3

(continuação)

\begin{tabular}{|c|c|c|c|c|c|c|c|c|c|c|}
\hline Id & Label & $\ldots$. & $\cdots$ & & $\cdots$ & $\cdots$ & & - Grau de entrada & Grau de saída & Grau \\
\hline $2853431 \ldots$ & Bazar das Meninas & $\mid \ldots$ & ... & $|\ldots|$ & $\ldots$ & $42 \mid$ & & 2 & 3 & 5 \\
\hline $1613289 \ldots$ & Fórum de Cultura do DF & $\cdots$ & $\ldots$ & $\ldots$ & $\cdots$ & 73 & 3 & 1 & 3 & 4 \\
\hline $5270879 \ldots$ & TJMT & $\ldots$ & $\ldots$. & $\ldots$ & $\ldots$ & $\ldots 2$ & 2 & 2 & 2 & 4 \\
\hline $5996389 \ldots$ & Tribunal de Justiça do Estado do Pará & $\ldots$ & $\ldots \mathrm{r}$ & no. & $\ldots$ & $\ldots 2$ & 2 & 3 & 1 & 4 \\
\hline $5264482 \ldots$ & Siren & $\ldots$ & $\ldots r$ & no. & $\ldots$. & $\ldots 8$ & 8 & 1 & 3 & 4 \\
\hline $2827873 \ldots$ & PLIC - Intervenções Urbanas / Street Art & $\ldots$ & $\ldots r$ & no. & $\ldots$ C & 08 & 8 & 4 & 0 & 4 \\
\hline $2842527 \ldots$ & O Último Cine Drive-in & $\ldots$ & $\ldots \mathrm{r}$ & no. & $\ldots$ & 4 & 10 & 4 & 0 & 4 \\
\hline $4002868 \ldots$ & Administração Regional do Guará & $\ldots$ & $\ldots$ & $\ldots$ & $\ldots$ & $\ldots 3$ & 3 & 4 & 0 & 4 \\
\hline $3737298 \ldots$ & Espaço Cultural Renato Russo 508 Sul & $\ldots$ & $\ldots r$ & no: & $\ldots$ & 23 & 3 & 4 & 0 & 4 \\
\hline $1474009 \ldots$ & Toninho do PSOL & ... & $\ldots r$ & no. & $\ldots$ & 385 & 5 & 2 & 2 & 4 \\
\hline $6683030 \ldots$ & Vizinhança Amiga - Águas Claras & $\ldots$ & $\ldots r$ & no. & $\ldots$ & 05 & 5 & 2 & 2 & 4 \\
\hline $1746330 \ldots$ & Comitê pela desmilitarização da polícia e da política no DF & $\cdots$ & $\ldots$ & $\ldots$ & $\cdots$ & 205 & 5 & 4 & 0 & 4 \\
\hline $8059135 \ldots$ & Revista Superinteressante & ... & $\ldots$ & $\ldots$ & $\ldots$ & $\ldots 5$ & 5 & 4 & 0 & 4 \\
\hline $3671804 \ldots$ & Casa de Repouso Petista Camarada (CRPC) & $\ldots$ & $\ldots r$ & no. & $\ldots$ & $\ldots 5$ & 5 & 4 & 0 & 4 \\
\hline $3952876 \ldots$ & Porque eu quis & $\cdots$ & $\cdots$ & ... & ... & $\ldots 5$ & 5 & 4 & 0 & 4 \\
\hline $1770492 \ldots$ & Hospital Santa Luzia - Brasilia & $\ldots$ & $\ldots r$ & no. & $\ldots 8=$ & 845 & 5 & 1 & 3 & 4 \\
\hline $2841280 \ldots$ & JSB DF - Juventude Socialista Brasileira do Distrito Federal & $\ldots$ & $\cdots$ & $\ldots$ & $\ldots$ & 95 & 5 & 2 & 2 & 4 \\
\hline $1803744 \ldots$ & Movimento Pobular Por Uma Ceilândia Melhor & $\ldots$ & $\ldots$ & $\ldots$ & $\ldots$ & 4 & 5 & 3 & 1 & 4 \\
\hline $1213239 \ldots$ & O Brasil Acordou & ... & ... & ... & $\ldots$ & $2 \mid 5$ & 5 & 2 & 2 & 4 \\
\hline $1580358 \ldots$ & Concursos/CorreioWeb & $\ldots$ & $\ldots r$ & no. & ... & $\ldots 7$ & 73 & 3 & 1 & 4 \\
\hline $2563588 \ldots$ & Rebarba & $\cdots$ & $\ldots$. & $\cdots$. & $\ldots$ & 558 & 8 & 3 & 1 & 4 \\
\hline $1209307 \ldots$ & SAMPA GRAFFITI & $\cdots$ & $\ldots$. & $\cdots$. & $\ldots$ & $\ldots 8$ & 8 & 4 & 0 & 4 \\
\hline $4880285 \ldots$ & SQS - Só Que Sim & $\cdots$ & ... & $\cdots$. & ... & 12 & 10 & 4 & 0 & 4 \\
\hline $2096929 \ldots$ & Debaixo do Bloco & $\cdots$ & $\ldots r$ & no. & $\ldots$ & 41 & 103 & 3 & 1 & 4 \\
\hline $2387972 \ldots$ & Vilada & $\ldots$ & $\ldots$ & ... & $\ldots$ & 4 & 103 & 3 & 1 & 4 \\
\hline $1318031 \ldots$ & Churros do Tio & $\cdots$ & $\ldots$ & $\cdots$. & ... & 4 & 10 & 4 & 0 & 4 \\
\hline $8163994 \ldots$ & RAF FOOD TRUCK & $\ldots$ & $\ldots$ & $\ldots$. & $\ldots$ & 1 & 10 & 4 & 0 & 4 \\
\hline $4934754 \ldots$ & Container Arroz Carreteiro Fest Food & $\ldots$ & $\ldots$ & $\ldots$. & $\ldots$ & 2 & 10 & 4 & 0 & 4 \\
\hline $1599504 \ldots$ & Latifas Food Truck & $\ldots$ & $\ldots$ & $\ldots$. & $\ldots$ & 0 & 10 & 4 & 0 & 4 \\
\hline $2173574 \ldots$ & Horta Comunitária da 114 Sul & $\ldots$ & $\ldots$ & ... & ... & 16 . & 10 & 4 & 0 & 4 \\
\hline $7131144 \ldots$ & Urbanistas por São Paulo & ... & $\ldots$ & ... . & ... & 1 & 10 & 2 & 2 & 4 \\
\hline $1491967 \ldots$ & Urban Arts Brasilia & $\ldots$ & $\ldots$ & ... & $\ldots$ & 26 & 10 . & 4 & 0 & 4 \\
\hline $1697669 \ldots$ & Aparelhinho & $\ldots$ & $\ldots$ & $\cdots$. & ... & 5 & 10 & 4 & 0 & 4 \\
\hline $1417778 \ldots$ & Ciclistas de Brasilia & $\cdots$ & $\ldots$ & no. & $\ldots$ & $91:$ & 10 & 4 & 0 & 4 \\
\hline $4671623 \ldots$ & Mutirão contra a PEC 37 & $\cdots$ & $\cdots$ & $\cdots$. & $\ldots$ & 182 & 2 & 2 & 2 & 4 \\
\hline $1253128 \ldots$ & Grupo Embaraca & $\ldots$ & $\ldots$ & $\ldots$. & $\ldots$ & & 4 & 2 & 2 & 4 \\
\hline
\end{tabular}


Tabela 6 - Fanpages (759 nós) que integram o grafo da figura 3

(continuação)

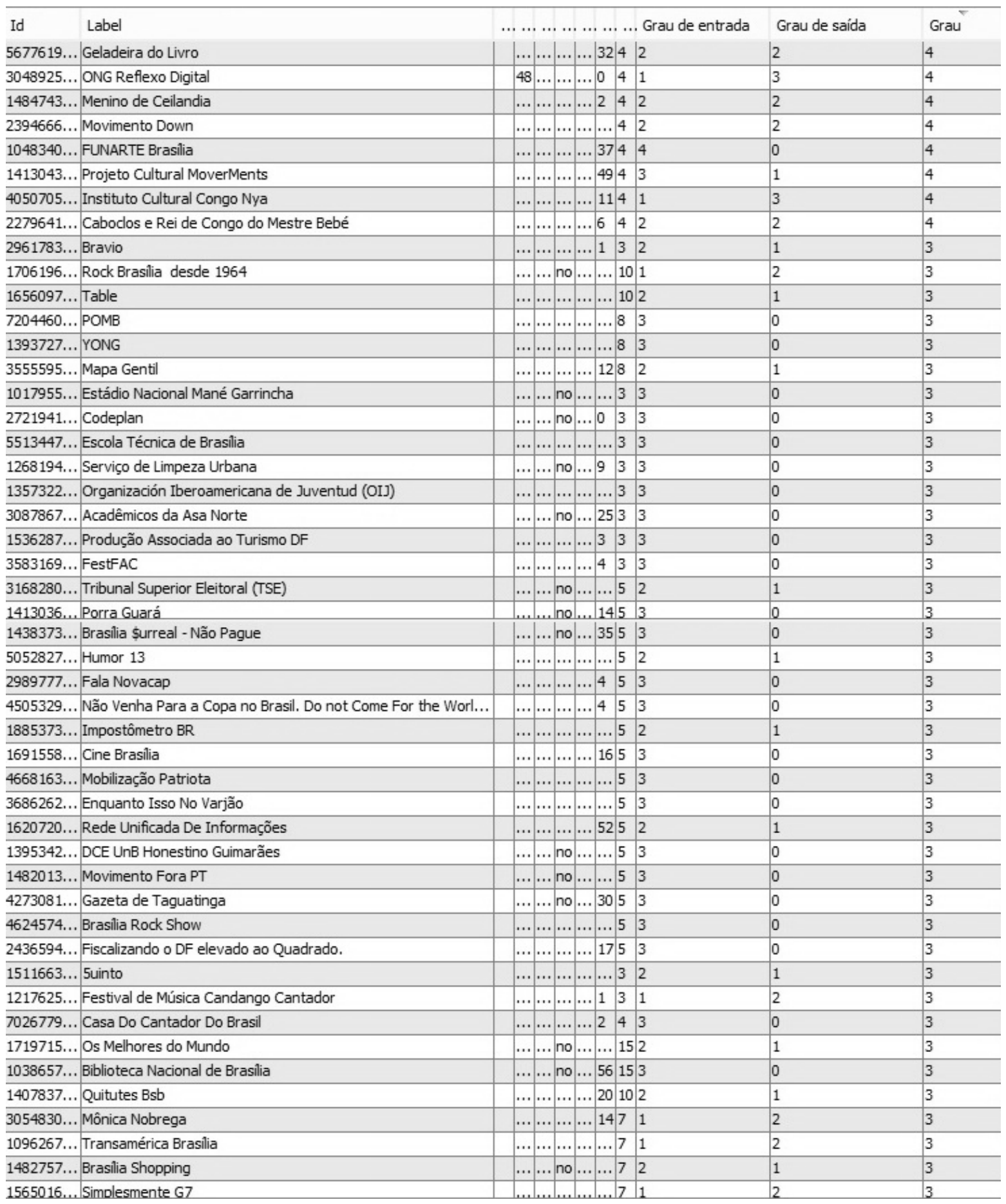


Tabela 6 - Fanpages (759 nós) que integram o grafo da figura 3

(continuação)

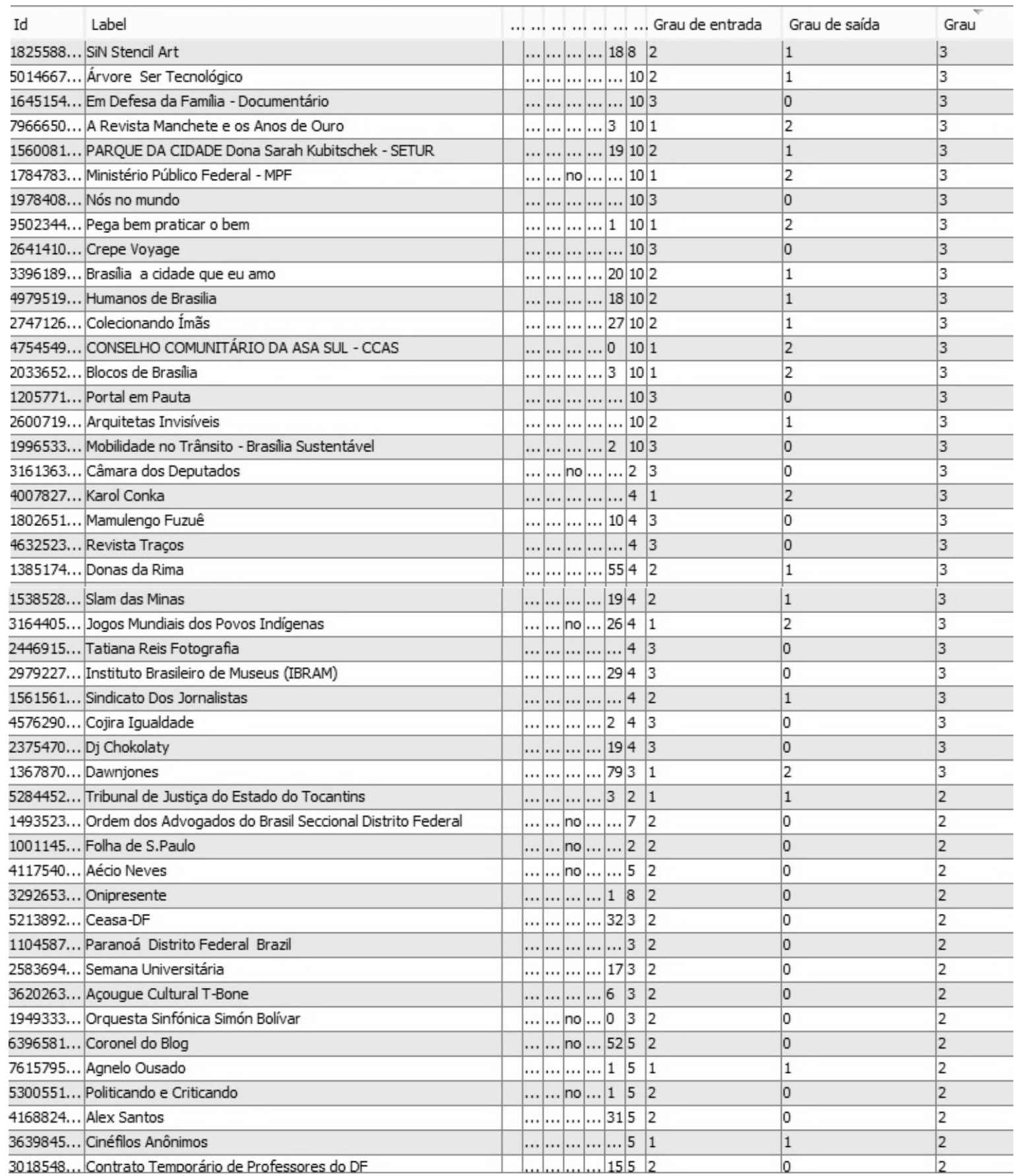


Tabela 6 - Fanpages (759 nós) que integram o grafo da figura 3

(continuação)

\begin{tabular}{|c|c|c|c|c|c|c|c|c|c|c|}
\hline Id & Label & $\ldots \ldots$ & .... & $\ldots$ & $\ldots$ & $\ldots$ & & - Grau de entrada & Grau de saída & Grau \\
\hline $5145240 \ldots$ & Boa do Samba - Brasilia & $\mid \ldots$ & $|\ldots|$ & $|\ldots|$ & $\ldots \mid 1$ & $|14|$ & & 2 & 0 & 2 \\
\hline $2412843 \ldots$ & Brasilia Marketing School & $\ldots$ & $\ldots$ & $\ldots$ & $\ldots$. & $\ldots$ & 5 & 2 & 0 & 2 \\
\hline $1646999 \ldots$ & Vestibular Cidadão - Braslia & $\ldots$ & $\ldots$ & $\ldots$ & $\ldots$. & $\ldots$ & 5 & 1 & 1 & 2 \\
\hline $1832461 \ldots$ & Brasilia Tátil & $\ldots$ & $\ldots r$ & no & $\ldots 2$ & 27 & 5 & 2 & 0 & 2 \\
\hline $2800982 \ldots$ & PT - DF & $\ldots$ & $\ldots r$ & no & $\ldots$. & $\ldots$ & 5 & 1 & 1 & 2 \\
\hline $5073478 \ldots$ & Paisagens da Memória: Museu Da Educação do Distrito Federal & $\ldots$ & $\ldots$ & $\ldots$ & $\ldots 2$ & 26 & 5 & 2 & 0 & 2 \\
\hline $2411744 \ldots$ & Conselho Regional de Enfermagem do Distrito Federal & $\ldots$ & $\ldots r$ & no & $\ldots$. & $\ldots$ & 5 & 1 & 1 & 2 \\
\hline $3805051 \ldots$ & CAUDF - Conselho de Arquitetura e Urbanismo do Distrito Fe... & $\ldots$ & $\ldots r$ & no & $\ldots 4$ & 40 & 5 & 2 & 0 & 2 \\
\hline $2158059 \ldots$ & Petrolão & $\ldots$ & $\cdots$ & $\ldots$ & $\ldots 1$ & 11 & 5 & 2 & 0 & 2 \\
\hline $4707507 \ldots$ & Instituto Socioambiental - ISA & $\ldots$ & $\ldots r$ & no & $\ldots$. & $\ldots$ & 5 & 1 & 1 & 2 \\
\hline $1864895 \ldots$ & Adote um Distrital & $\ldots$ & $\ldots$ & $\ldots$ & $\ldots 5$ & 5 & 5 & 2 & 0 & 2 \\
\hline $5144380 \ldots$ & Cyb3rgh0sts & $\ldots$ & $\ldots$ & $\ldots$ & $\ldots$ & 1 & 5 & 2 & 0 & 2 \\
\hline $2316587 \ldots$ & Fora Agnulo & $\ldots$ & $\ldots$ & $\ldots$ & $\ldots$ & 1 & 5 & 2 & 0 & 2 \\
\hline $1393061 \ldots$ & Pedal Santa Maria DF & 58 & $3 \ldots r$ & no & $\ldots c$ & 0 & 5 & 1 & 1 & 2 \\
\hline $3384698 \ldots$ & DF Ceilândia & $\ldots$ & $\ldots$ & $\ldots$ & $\ldots$. & $\ldots$ & 5 & 2 & 0 & 2 \\
\hline $2005730 \ldots$ & Vírgula 7 Produções & $\ldots$ & $\ldots r$ & no & $\ldots$ & 45 & 5 & 2 & 0 & 2 \\
\hline $3343019 \ldots$ & Megafônica & $\ldots$ & $\ldots$ & $\ldots$ & $\ldots 7$ & 7 & 15 & 1 & 1 & 2 \\
\hline $5265459 \ldots$ & Miscelânea & $\ldots$ & $\ldots$ & $\ldots$ & $\ldots 2$ & 26 & 15 & 1 & 1 & 2 \\
\hline $4783526 \ldots$ & Barracão & $\ldots$ & $\ldots$ & $\ldots$ & $\ldots$. & $\ldots$ & 15 & 1 & 1 & 2 \\
\hline $1258633 \ldots$ & Águas Claras Shopping & $\ldots$ & $\ldots r$ & no & $\ldots$. & $\ldots$ & 10 & 2 & 0 & 2 \\
\hline $1405349 \ldots$ & Bemdoado & $\ldots$ & $\ldots$ & $\ldots$ & $\ldots 1$ & 10 & 7 & 2 & 0 & 2 \\
\hline $2077153 \ldots$ & Brasilia Futebol Clube & $\ldots$ & $\ldots$ & $\ldots$ & $\ldots$. & $\ldots$ & 7 & 1 & 1 & 2 \\
\hline $2001783 \ldots$ & Emprego DF & $\ldots$ & $\ldots$ & $\ldots$ & $\ldots$. & $\ldots$ & 7 & 2 & 0 & 2 \\
\hline $2853287 \ldots$ & Acontece Brasilia DF & $\ldots$ & $\ldots$ & no & $\ldots$. & t... & 7 & 2 & 0 & 2 \\
\hline $1203096 \ldots$ & Desperta Brasilia - Oficial & $\ldots$ &.$\ldots r$ & no & $\ldots \mid$. & $\ldots$ & 7 & 1 & 1 & 2 \\
\hline $1081874 \ldots$ & Brasilia & $\ldots$ & $\cdots$ & $\ldots$ & $\ldots 8$ & 89 & 7 & 2 & 0 & 2 \\
\hline $1788404 \ldots$ & Projeto 767 & $\ldots$ & $\ldots$ & $\ldots$ & $\ldots 3$ & 3 & 7 & 2 & 0 & 2 \\
\hline $3091808 \ldots$ & Melhores Destinos & $\ldots$ & $\ldots r$ & no & $\ldots$. & $\ldots$ & 7 & 2 & 0 & 2 \\
\hline $1710630 \ldots$ & Graffiti - ARTE Urbana em Florianópolis & $\ldots$ & $\ldots r$ & no & $\ldots 2$ & 448 & 8 & 1 & 1 & 2 \\
\hline $1448551 \ldots$ & CASA 68 & $\ldots$ & $\ldots$ & $\ldots$ & $\ldots 9$ & 9 & 10 & 2 & 0 & 2 \\
\hline $3901011 \ldots$ & MOB Manual de Ocupação de Brasilia & $\ldots$ & $\ldots$ & $\ldots$ & ... & $\ldots$ & 10 & 2 & 0 & 2 \\
\hline $1592880 \ldots$ & Amigos do Parque Burle Marx & $\ldots$ & $\ldots$ & $\ldots$ & $\ldots 3$ & 3 & 10 & 2 & 0 & 2 \\
\hline $6283982 \ldots$ & Instituto Historico e Geografico do DF & $\ldots$ & $\ldots$ & $\ldots$ & $\ldots$. & $\ldots$ & 10 & 2 & 0 & 2 \\
\hline $4760998 \ldots$ & Brasilia Cidade Parque & $\ldots$ & $\ldots$ & $\ldots$ & $\ldots 3$ & 3 & 10 & 2 & 0 & 2 \\
\hline $5869713 \ldots$ & Lab 61 & $\ldots$ & $\ldots$ & $\ldots$ & $\ldots 2$ & 4 & 10 & 2 & 0 & 2 \\
\hline $1741166 \ldots$ & Defender/RS Defesa Civil do Patrimônio Histórico & $\ldots$ & $\ldots$ & $\ldots$ & $\ldots$ & $\ldots$ & 10 & 1 & 1 & 2 \\
\hline $1410462 \ldots$ & Zoo: Pet s e Bichos & $\ldots$ & $\ldots$ & $\ldots$ & $\ldots 5$ & 5 & 10 & 2 & 0 & 2 \\
\hline $5080057 \ldots$ & Projeto Pilotis & $\ldots$ & $\ldots$ & $\ldots$ & $\ldots$ & 4 & 10 & 2 & 0 & 2 \\
\hline $5849511 \ldots$ & Fórum de Produtores Culturais na UnB & $\ldots$ & $\ldots$ & $\ldots$ & $\ldots$ & 4 & 4 & 1 & 1 & 2 \\
\hline $6102946 \ldots$ & EXPO HIP HOP Brasil & $\ldots$ & $\ldots$ & $\ldots$ & $\ldots$ & 16 & 4 & 2 & 0 & 2 \\
\hline $2203702 \ldots$ & Autismo E Realidade & $\ldots$ & $\ldots r$ & no & $\ldots$ & $\ldots$ & 4 & 2 & 0 & 2 \\
\hline $4696306 \ldots$ & Sem Sentido & $\ldots$ & $\ldots$ & $\ldots$ & $\ldots$ & 0 & 4 & 2 & 0 & 2 \\
\hline $1396155 \ldots$ & Associação Ludocriarte - Brinquedoteca Comunitária \& Ponto... & $\ldots$ & $\ldots$ & $\ldots$ & $\ldots 3$ & 3 & 4 & 1 & 1 & 2 \\
\hline $3838944 \ldots$ & Vera Verônika & $\ldots$ & $\ldots$ & $\ldots$ & $\ldots$. & $\ldots$ & 4 & 2 & 0 & 2 \\
\hline $6302990 \ldots$ & Ylê Axé Oyá Bagan Comunidade Tradicional de Terreiro - Br... & $\ldots$ & $\ldots$ & $\ldots$ & $\ldots$ & 16 & 4 & 2 & 0 & 2 \\
\hline $6787179 \ldots$ & Mobilização Nacional Indígena & $\ldots$ & $\ldots$ & $\ldots$ & $\ldots 6$ & 65 & 4 & 2 & 0 & 2 \\
\hline $1552790 \ldots$ & Tribo das Artes & $\ldots$ & $\ldots$ & $\ldots$ & $\ldots$ & 7 & 4 & 2 & 0 & 2 \\
\hline $2402291 \ldots$ & Afapab-Associacão dos Familiares Amiaos e Pais dos Autista... & $\ldots$ & $\ldots$ & $\ldots$ & $\ldots$ & 47 & & 1 & 1 & 2 \\
\hline
\end{tabular}


Tabela 6 - Fanpages (759 nós) que integram o grafo da figura 3

(continuação)

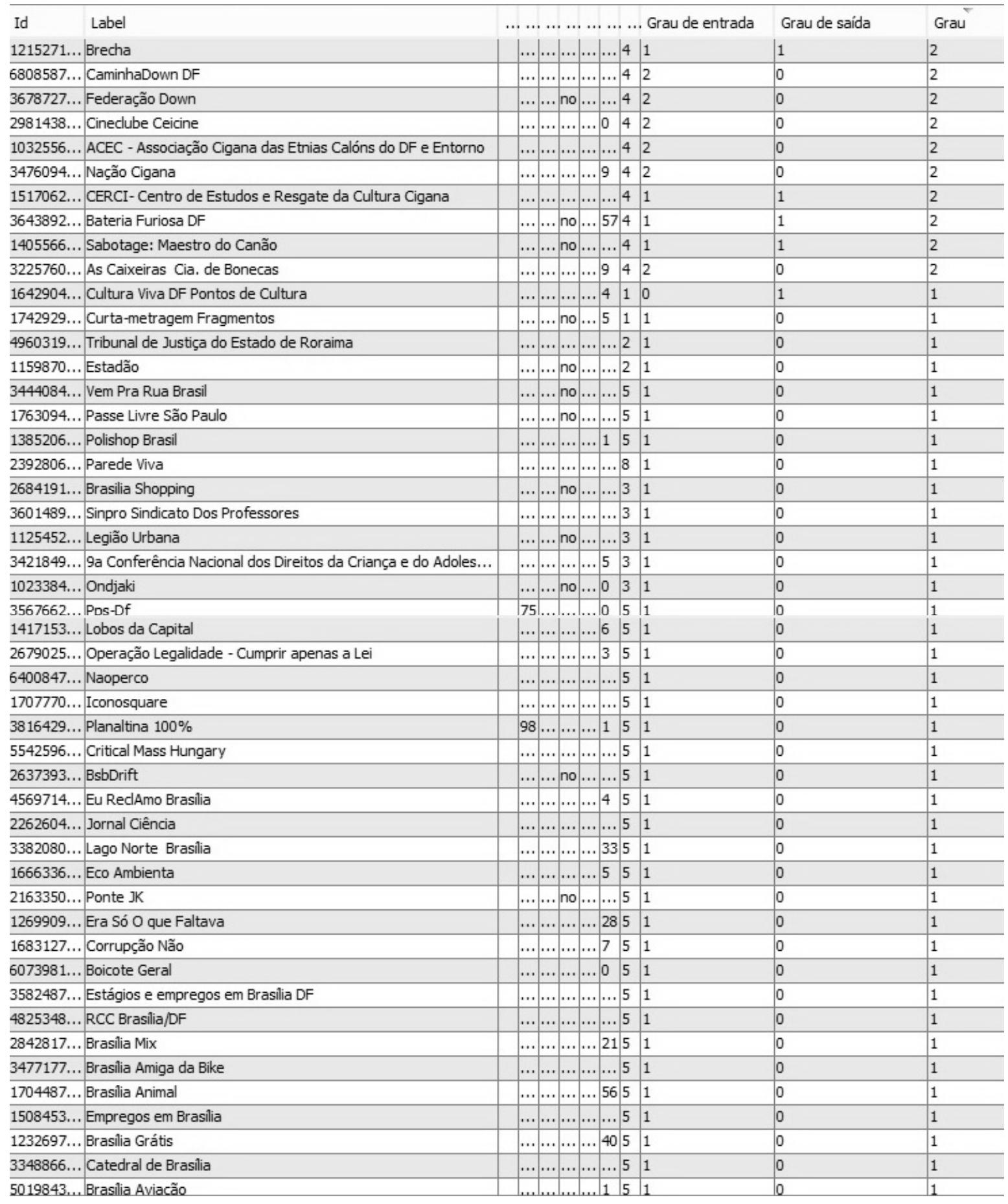


Tabela 6 - Fanpages (759 nós) que integram o grafo da figura 3

(continuação)

\begin{tabular}{|c|c|c|c|c|c|c|c|c|c|}
\hline Id & Label & $\ldots \ldots$ & $\cdots$ & $\cdots$. & $\cdots$ & $\cdots$ & ... Grau de entrada & Grau de saída & Grau \\
\hline $5922695 \ldots$ & Brasilia Vôlei & $|\cdots|$ & ...... & ... & $\ldots$. & $\ldots 5$ & 5 & 0 & 1 \\
\hline $1875986 \ldots$ & BSB Musical & $\ldots$ & ...... & ... . & $\ldots 2$ & 245 & 5 & 0 & 1 \\
\hline $5779727 \ldots$ & Miss Distrito Federal Universo & $\cdots$ & ..... & ... . & $\ldots 1$ & 105 & 5 & 0 & 1 \\
\hline $5837516 \ldots$ & Guia da minha cidade Distrito Federal & $\ldots$ & ...... & ... . & $\ldots 0$ & 05 & 5 & 0 & 1 \\
\hline $2033641 \ldots$ & Federação Candanga de Karate do Distrito Federal & ... & ..... & .... & $\ldots 3$ & 395 & 5 & 0 & 1 \\
\hline $4816872 \ldots$ & CDL-DF & $\ldots$ & $\ldots n$ & רo... & $\ldots 2$ & 255 & 5 & 0 & 1 \\
\hline $5586418 \ldots$ & Conselho Regional de Medicina Veterinária do Distrito Federal & ... & ..... & ... . & $\ldots 9$ & 95 & 1 & 0 & 1 \\
\hline $2193285 \ldots$ & Conselho Regional De Farmacia Do Distrito Federal CRFDF & $\ldots$ & $\ldots n$ & רo... & $\ldots 1$ & 185 & 5 & 0 & 1 \\
\hline $1717076 \ldots$ & TJDFT - Tribunal de Justiça do Distrito Federal e Territórios & ... & $\ldots n$ & רo... & ... & $\ldots 5$ & 1 & 0 & 1 \\
\hline $1783874 \ldots$ & Eita Pomba & $\ldots$ & ..... & ... . & $\ldots 3$ & 345 & 1 & 0 & 1 \\
\hline $1425366 \ldots$ & Rodolfo Mohr & $\ldots$ & ..... & ..... & $\ldots 9$ & 95 & 1 & 0 & 1 \\
\hline $3824104 \ldots$ & Rádio Web Sobradinho-DF & $\ldots$ & ...... & ... . & $\ldots 1$ & 15 & 5 & 0 & 1 \\
\hline $3981516 \ldots$ & Fora Agnelo & 14. & ..... & ... . & $\ldots 0$ & 05 & 5 & 0 & 1 \\
\hline $1714857 \ldots$ & Daqui de Brasilia & $\cdots$ & ..... & ... . & $\ldots 2$ & 235 & 5 & 0 & 1 \\
\hline $5805114 \ldots$ & Brasilia Noticias & $\cdots$ & ..... & ... . & $\ldots 1$ & 125 & 5 & 0 & 1 \\
\hline $1490517 \ldots$ & Anon¥mous São Sebastião-DF & $\cdots$ & ...... & .... & $\ldots 1$ & 15 & 1 & 0 & 1 \\
\hline $1659867 \ldots$ & Movimento Em Defesa De Santa Maria - Df & $\cdots$ & ..... & ... . & $\ldots 1$ & 15 & 1 & 0 & 1 \\
\hline $2913770 \ldots$ & Santa Maria DF & $\cdots$ & ...... & .... & $\ldots 8$ & 85 & 1 & 0 & 1 \\
\hline $1254350 \ldots$ & Rádio JK FM & $\cdots$ & ..... & ... . & $\ldots 6$ & 665 & 1 & 0 & 1 \\
\hline $1402282 \ldots$ & Flagrante Sobradinho & ... & ...... & .... & .... & ... 5 & 5 & 0 & 1 \\
\hline $2175480 \ldots$ & PT de lutas & ... & ..... & ... . & $\ldots 4$ & 45 & 1 & 0 & 1 \\
\hline $2620743 \ldots$ & Sobradinho2 da Depressão & $\cdots$ & ..... & .... . & .... & ... 5 & 1 & 0 & 1 \\
\hline $5003062 \ldots$ & Resista Contra o Sistema & $\cdots$ & ..... & .... & $\ldots 3$ & 35 & 1 & 0 & 1 \\
\hline $1010436 \ldots$ & Meu Paranoá,com & $\ldots$ & ...... & $\ldots$. & $\ldots 1$ & 105 & 51 & 0 & 1 \\
\hline $2971514 \ldots$ & Degustação Sonora & -.. & $\ldots n$ & no: & $\ldots 2^{2}$ & 23 & 1 & 0 & 1 \\
\hline $2376877 \ldots$ & Rede Aleluia & $\cdots$ & $\ldots n$ & no. & $\ldots 9$ & 973 & 1 & 0 & 1 \\
\hline $5384057 \ldots$ & II Bienal Brasil do Livro e da Leitura - Brasilia & $\cdots$ & $\ldots .$. & .... & $\ldots 2$ & 283 & 1 & 0 & 1 \\
\hline $5726110 \ldots$ & III Festival de Ópera de Brasilia & $\cdots$ & $\ldots .$. & .... & $\ldots 1$ & 13 & 1 & 0 & 1 \\
\hline $1612863 \ldots$ & Procon-DF & $\cdots$ & $\ldots .$. & ... & $\ldots 2$ & 23 & 1 & 0 & 1 \\
\hline $2324921 \ldots$ & Museu Nacional da República - Brasilia & $\cdots$ & $\ldots n$ & no. & $\ldots 7$ & 73 & 1 & 0 & 1 \\
\hline $9419679 \ldots$ & KB Tambo Hotel \& Tours & $\cdots$ & $\ldots .$. & ... & $\ldots 1$ & 111 & 151 & 0 & 1 \\
\hline $5031174 \ldots$ & Coletivo Palavra & $\cdots$ & $\ldots .$. & .... & .... & $\ldots 1$ & 151 & 0 & 1 \\
\hline $5928745 \ldots$ & VibeFm Brasil & $\cdots$ & $\ldots$. & ... & ... & $\ldots 1$ & 151 & 0 & 1 \\
\hline $9145941 \ldots$ & Vanessa da Mata & $\ldots$ & $\ldots n$ & no. & .... & $\ldots 1$ & 151 & 0 & 1 \\
\hline $1672514 \ldots$ & Festival BB Seguridade & $\cdots$ & ..... & ... . & $\ldots 4$ & 41 & 151 & 0 & 1 \\
\hline $2997402 \ldots$ & Festival Itinerante Rock E Quadrinhos & $\cdots$ & ..... & $\cdots$. & $\ldots 8$ & \begin{tabular}{l|l}
8 & 1 \\
\end{tabular} & 151 & 0 & 1 \\
\hline $7861377 \ldots$ & CAIXA Cultural Brasilia & ... & ... n & no. & ... & $\ldots 1$ & 151 & 0 & 1 \\
\hline $2349782 \ldots$ & National Geographic & $\cdots$ & $\ldots n$ & no. & ... & $\ldots 1$ & 151 & 0 & 1 \\
\hline $2684710 \ldots$ & Pão com Ovo & $\cdots$ & ..... & .... & $\ldots 0$ & 0 & 151 & 0 & 1 \\
\hline $3250103 \ldots$ & Balde d Água & $\cdots$ & ..... & .... & $\ldots 1$ & 11 & 101 & 0 & 1 \\
\hline $7483393 \ldots$ & Calourada Uniceub & $\cdots$ & ... n & no. & ... & $\ldots 1$ & 101 & 0 & 1 \\
\hline $2089589 \ldots$ & Frederico Gomes - Fotografia & $\cdots$ & $\ldots n$ & no. & $\ldots 5$ & 531 & 101 & 0 & 1 \\
\hline $1440868 \ldots$ & Fotografias pela cidade & $\cdots$ & $\ldots n$ & no. & $\ldots 3$ & 3 & 101 & 0 & 1 \\
\hline $2111514 \ldots$ & Picnik & $\cdots$ & $\ldots n$ & no. & $\ldots 1$ & 11 & 101 & 0 & 1 \\
\hline $5199837 \ldots$ & Monstros de Brasilia & $\ldots$ & ...... & .... & $\ldots 1$ & 151 & 101 & 0 & 1 \\
\hline $3824065 \ldots$ & Natura Brasilia & $\cdots$ & ...... & .... & $\ldots 4$ & 47 & 1 & 0 & 1 \\
\hline $1426898 \ldots$ & José Roberto Arruda & $\cdots$ & $\ldots n$ & no. & $\ldots 8$ & 867 & 1 & 0 & 1 \\
\hline $1642979 \ldots$ & Terceira Iareia Batista de Brasilia & $\ldots$ & $\ldots \mathrm{n}$ & no. & $\ldots$. & & 1 & 0 & 1 \\
\hline
\end{tabular}


Tabela 6 - Fanpages (759 nós) que integram o grafo da figura 3

(continuação)

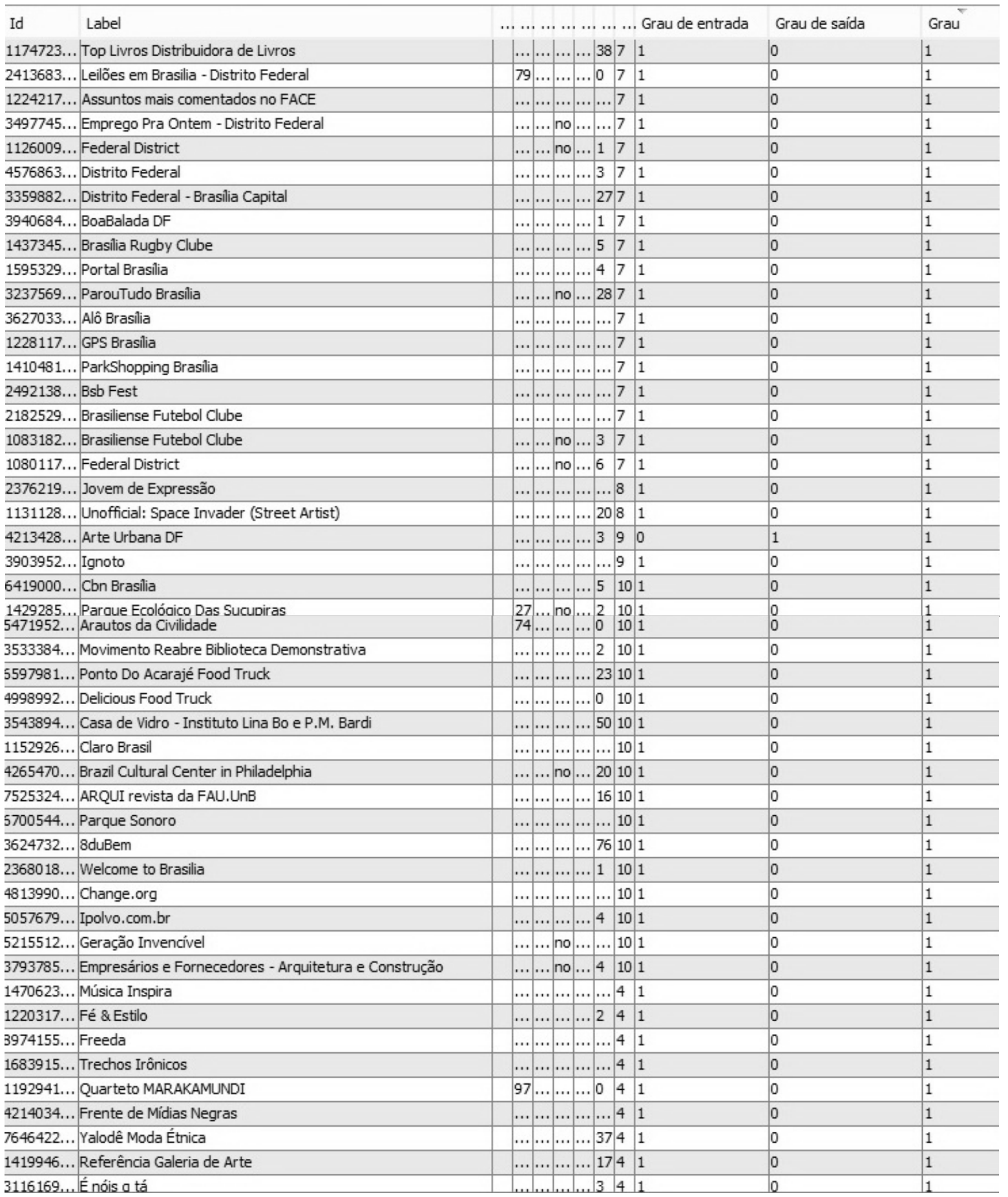


Tabela 6 - Fanpages (759 nós) que integram o grafo da figura 3

(conclusão)

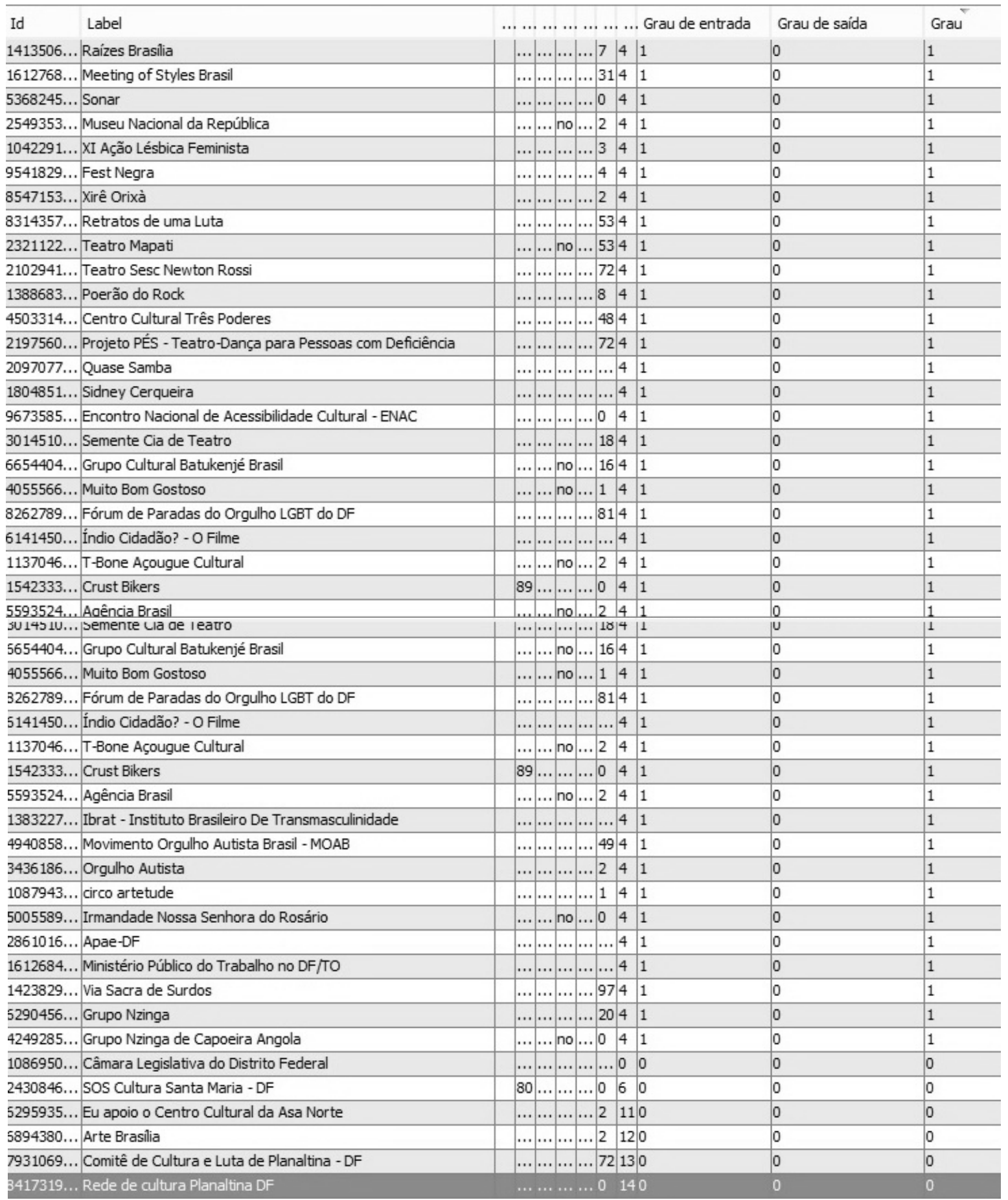

Fonte: Elaborado pela autora. Informações coletadas na plataforma Facebook com acesso em 30 jan. 2016. 